MARCIA FURTADO AVANZA

Danton Jobim, o mediador de duas culturas:

por uma pedagogia do jornalismo

São Paulo

2007 
MARCIA FURTADO AVANZA

\title{
Danton Jobim, o mediador de duas culturas: por uma pedagogia do jornalismo
}

\begin{abstract}
Tese de doutorado apresentada ao Programa de Pós-Graduação em Ciências da Comunicação da Escola de Comunicações e Artes da Universidade de São Paulo, Área de Concentração: Estudo dos Meios da Produção Mediática, como exigência parcial para obtenção do título de Doutor na área de Comunicação, sob a orientação do Prof. Dr. José Marques de Melo.
\end{abstract}

São Paulo 


\section{FOLHA DE APROVAÇÃO}

\section{Marcia Furtado Avanza}

Danton Jobim, o mediador de duas culturas:

por uma pedagogia do jornalismo

Tese apresentada à Escola de Comunicações e Artes da Universidade de São Paulo para obtenção do título de Doutor.

Área de Concentração: Estudo dos Meios da Produção Mediática

Aprovado em:

\section{Banca Examinadora}

Prof. Dr.

Instituição:

Assinatura

Prof. Dr.

Instituição:

Assinatura

Prof. Dr.

Instituição:

Assinatura

Prof. Dr.

Instituição:

Assinatura

Prof. Dr.

Instituição:

Assinatura 
“Mestre é aquele que não só ensina, mas que de repente aprende..." Guimarães Rosa 
Para Gustavo, Felipe, Rafael, José Augusto Jr. e Paulo Roberto, os cinco homens que iluminaram minha vida. Para Caliope, a única mulher, por sua inspiração e por me ensinar o verdadeiro significado do amor. 


\section{Agradecimentos}

Antes de tudo, obrigada ao Prof. Dr. José Marques de Melo, um orientador sempre presente, capaz de dar "puxões de orelha" nos momentos mais necessários.

Aos colegas do Gabinete do Reitor: Miriam Imada, Adriana Cruz, Ernani Coimbra, Thaís Venosa, Laura Fuzaro, Marcelo Cuzziol, José Roberto Sanches e Wildner Vilaça Antonio. A todos eles, devo muito do meu trabalho. Aos demais colegas da reitoria da USP, que direta ou indiretamente contribuíram para que eu conseguisse terminar esta pesquisa, agradeço através de Márcia Bispo e de Clélia Affonso Monteiro. Sem ajuda delas, nada teria conseguido.

Aos professores da Fiam, com quem pude trocar experiências fundamentais para a construção do trabalho, especialmente ao professor Rodrigo Manzano, pela leitura atenta e observações pertinentes.

À Associação Brasileira de Imprensa - ABI, agradeço por meio de seu presidente Maurício Azedo e da bibliotecária chefe Vilma Santos Oliveira, pela inestimável colaboração.

Ao Prof. Dr. Carlos Humes, ouvinte atento das minhas dúvidas e brilhante conselheiro acadêmico.

À Profa. Dra. Ana Maria Sousa, exemplo de verdadeira professora e minha eterna reitora, pelas discussões essenciais sobre pedagogia. 


\section{Resumo}

Analisar a contribuição do jornalista Danton Jobim, primeiro professor a ocupar a cadeira de Técnicas de Redação Jornalística no Curso de Jornalismo da Universidade do Brasil constitui o objetivo central desta pesquisa, cuja meta é contribuir para o desenvolvimento de uma pedagogia do jornalismo. A partir de seu curso de Metodologia de Ensino do Jornalismo no CIESPAL, em Quito, Equador, buscou-se compreender suas propostas para o ensino do jornalismo, partindo da análise textual dos volumes preparados para embasar a formação de professores de toda a América do Sul. Resgatou-se também sua trajetória na imprensa brasileira, principalmente no Diário Carioca, onde promoveu a maior reforma no jornalismo do país na década de 1950, treinando estudantes de diferentes áreas para atuar no jornalismo. Suas idéias foram reconstituídas através de entrevistas com companheiros da imprensa e da $A B I$. $A$ pesquisa evidencia que Jobim foi o responsável pela mediação entre os modelos norte-americano e europeu de ensino do jornalismo. Ele propõe a formação de um jornalista dotado de conhecimentos técnicos e humanísticos adequados ao seu tempo, sendo capaz de se reciclar para exercer, por meio do jornalismo, uma importante função social, informando, analisando e criticando os acontecimentos cotidianos e contribuindo para a formação do homem contemporâneo.

\section{PALAVRAS-CHAVE:}

Jornalismo. Pedagogia do Jornalismo, História do Jornalismo, Danton Jobim. América Latina. 


\section{Abstract}

To analyze the contribution of journalist Danton Jobim, first professor to occupy the chair of Techniques of Editorial Writing for Newspapers, at the Universidade of Brasil, is the central objective of this research, whose goal is to contribute towards the development of pedagogy in journalism. Starting from his Methodology Course for teaching Journalism at CIESPAL, in Quito, Ecuador, a search was undertaken to understand his proposals for teaching journalism, beginning from the textual analysis of volumes prepared to sustain the development of teachers for all South America. His trajectory in the Brazilian press was also redeemed, especially in the Diário Carioca, where he promoted the largest reform in journalism of the country during the decade of 1950, training students of different areas to work in journalism. His ideas were reconstructed through interviews with colleagues in the press and $\mathrm{ABI}$ (Brazilian Press Association). The research points out that Jobim was responsible for mediation between North American and European models to teach journalism. He proposes a journalist with technical and humanistic knowledge of his time, who would be able to recycle through journalism, an important social function, informing, analyzing and criticizing the daily news and contributing towards the formation of contemporary man.

\section{KEY-WORDS:}

Journalism. Pedagogy of Journalism, History of Jornalism, Danton Jobim, Latin America. 


\title{
Danton Jobim, o mediador de duas culturas:
}

\author{
por uma pedagogia do Jornalismo
}

\section{Sumário}

INTRODUÇÃO

1 O ENSINO DO JORNALISMO NO BRASIL: DAS INICIATIVAS PIONEIRAS AO CURSO NA UNIVERSIDADE DO BRASIL 35

1.1 Experiências pioneiras 39

1.2 O Jornalismo na Universidade: a Escola de Jornalismo Cásper Líbero 43

1.30 curso na Universidade do Brasil 48

1.4 Os primeiros currículos do Curso de Jornalismo 54

2 BIOGRAFIA - UMA VIDA DEDICADA À IMPRENSA 61

3 O PENSAMENTO JORNALÍSTICO DE DANTON JOBIM 75

3.1 Jornalismo e opinião pública __ 76

3.2 Jornalismo e técnica _ 78

3.3 Imprensa norte-americana versus imprensa latino-americana __ 82

3.4 Ética na imprensa ___ 84

3.5 Jornalismo e literatura __ 85

3.6 Jornalismo e História ___ 87

4 A ESCOLA DE JORNALISMO NO DIÁRIO CARIOCA

5 A PEDAGOGIA DO JORNALISMO, SEGUNDO DANTON JOBIM_ 106

5.1 O objeto do ensino do jornalismo 106

5.1.1 Formação e Informação ___ 110

5.1.2 Formação profissional — 116

$5.2 \mathrm{O}$ aluno de jornalismo 118

$5.3 \mathrm{O}$ professor de jornalismo __ 126

5.40 currículo _ 131

5.4.1 O que se ensina na escola de jornalismo ___ 134

5.4.2 As humanidades no curso de Jornalismo ___ 136

5.4.3 O ensino da Geografia e da História na Escola de Jornalismo ___ 141

5.4.4 O ensino da Língua e da Literatura na Escola de Jornalismo ___ 150

5.4.5 Ensino das disciplinas profissionais___ 154

5.50 método de ensino__ 161

6 O ENSINO ATUAL NAS ESCOLAS PIONEIRAS 
7 CONSIDERAÇÕES FINAIS 202 REFERÊNCIAS BIBLIOGRÁFICAS 205 ANEXOS 216 


\section{Introdução}

Foi de Otto Groth a tentativa inicial de obter o reconhecimento do jornalismo como ciência. Ele, que iniciava sua carreira jornalística em 1906, na Alemanha, em 1948 passou a dedicar-se à docência e à pesquisa, assumindo a cátedra de "Ciência de Jornalismo" no Instituto de Jornalismo Ilustrado de Munique. Embora existisse a intenção de classificar a ciência jornalística dentro de outras categorias, como a Psicologia Social, a História e a "Publicística", Groth analisou a imprensa em aspectos que não se resumiam à preparação e difusão das notícias, mas de sua relação com a vida e com a cultura. Além disso, analisou sua relação com as demais ciências, chegando à conclusão de que não se poderia colocar o Jornalismo dentro de outros ramos da Ciência Social, já que seus problemas e soluções não se encaixavam dentro da realidade das outras disciplinas (BUENO, 1972).

No mesmo ano de 1948, um brasileiro também assumia uma cátedra de jornalismo dentro de outra universidade; desta vez, na Faculdade Nacional de Filosofia da Universidade do Brasil, situada na então Capital Federal, o Rio Janeiro. Danton Jobim tinha mais coisas em comum com Otto Groth. Nasceu no mesmo ano em que este último iniciou sua carreira, 1906, e também se dedicou por muitos anos à atividade jornalística. Mas sua grande contribuição foi disseminar a perspectiva brasileira de análise do jornalismo em países da Europa e da América do Norte (MARQUES DE MELO, 2003a). 
Como Groth, Jobim também analisou o jornalismo a partir do impresso, mesmo numa época em que o rádio, a TV e o cinema já tinham um significativo papel na circulação das informações. Porém, Marques de Melo (1983, p. 11) entende que Jobim manteve-se fiel "ao 'espírito do jornalismo' entendendo-o como 'necessidade social' que assume o caráter de 'informação' cujos 'atributos essenciais' são aqueles apontados por Jacques Kaiser: 'universalidade e instantaneidade'”. Desta forma, a essência do jornalismo estaria presente no fluxo de informações atuais dos jornais e também nos espaços das outras mídias contemporâneas, não comprometendo o resultado de suas pesquisas e reflexões.

Jobim entendia o jornalismo como mais do que uma simples atividade profissional. Suas reflexões acerca do tema mostram que para ele o jornalismo era, sobretudo, "um exercício superior da inteligência e da cultura" (AZEVEDO FILHO, 1981, p.15). Da mesma forma, a pesquisa de Groth é descrita como uma investigação no "campo entero de la vida y la cultura. Y ello porque los periódicos y revistas son universales - segun su contenido y en razón de su modo de ser, obligando por tanto a una contemplación universal” (BELAU apud BUENO, 1972, p.5). Como explica Santos (2003, p.68), Groth entendia cada edição de jornal como parte de um todo,

de uma idéia, que se apresenta periodicamente (periodicidade), abrangendo assuntos que dizem respeito à realidade objetiva $e$ ao imaginário e a desejos humanos (universalidade), ligados ao presente, ao agora, e não ao seu passado (atualidade), e que são disseminados em termos geográficos sociais (difusão). 
Jobim também entendia que a compreensão do jornalismo ia muito além da técnica. Para ele, jornalismo tem sua própria "verdade", que não pode ser a de um sociólogo ou de um historiador, porque é uma hipótese impossível de ser verificada através de processos de que eles se servem. Como explica, é "uma verdade por assim dizer provisória e contingente" (2003, p.28). Ele separava o jornalismo das demais ciências, reconhecendo, contudo, sua interação. No entanto, entendia que o jornalismo no Brasil não dispunha de informações ou de dados confiáveis que pudessem promover um entendimento maior do fenômeno.

Um de seus projetos, tornado público em 1958, era o de criar um centro de pesquisa em jornalismo, o que ele chamou de Instituto de Estudos e Pesquisas sobre a Informação (IEPI), que envolveria seus alunos da Universidade do Brasil e contaria com o apoio de outras entidades, como a Fundação Getúlio Vargas. Para ele, só era possível estudar o fenômeno jornalístico a partir de um "instrumental adequado ao emprego dos modernos métodos de investigação sobre a informação em geral e em particular". Incluíam-se aí os estudos sobre os meios de comunicação da época, como a imprensa, o rádio e a televisão. Embora reforçasse a necessidade imperativa da criação dessa instituição, tal organismo jamais saiu do plano das idéias, por falta de apoio ou disponibilidade, já que Jobim atuava ao mesmo tempo na carreira docente e na atividade jornalística, assumindo inclusive a responsabilidade de direção de jornais. 
O primeiro centro de estudos de jornalismo só foi criado anos mais tarde pelo professor Luiz Beltrão, depois de seu trabalho no Ciespal Centro Internacional de Estudos Superiores de Comunicação para a América Latina, onde conheceu tendências internacionais de pesquisa no campo do jornalismo e da comunicação social. O Instituto de Ciências da Informação (ICINFORM) foi instalado em 13 de dezembro de 1963, na Universidade Católica de Pernambuco, com a finalidade de oferecer um suporte ao curso de jornalismo que dirigia, estabelecer uma estratégia de aproximação com os órgãos da grande imprensa local que resistiam à formação universitária de jornalista e analisar o jornalismo a partir do fenômeno da comunicação de massa, com perspectivas interdisciplinares.

Mas quando se analisa o cenário dos projetos de Groth e Jobim, as comparações param por aqui. Primeiro porque Groth desenvolvia suas pesquisas em um país - a Alemanha - com tradição de estudos na área de imprensa, ou da "Periodistika". Ali foi defendida, na Universidade de Leipzig, ainda no século XVII, a primeira tese sobre o jornalismo, por Tobias Peuce. Além disso, também foi lá, em Leipzig, que circulou o primeiro jornal diário da história da imprensa (DIAS, 2000, p.199). O país também foi pioneiro, logo depois dos Estados Unidos, na iniciativa de criar um instituto de jornalismo, em 1917.

O contexto brasileiro enfrentado por Jobim era bem diferente. Ele iniciava sua docência num país praticamente sem nenhuma pesquisa na área, convivendo com uma imprensa de padrões e formatos já superados, e que havia chegado com muito atraso (1808), mesmo se comparada com 
seus vizinhos da América Latina, que tiveram tipografias desde o século XVI. Além disso, a maior parte dessa mesma imprensa rejeitava a possibilidade de um curso superior que pudesse formar profissionais qualificados.

\section{O curso de Jornalismo}

Entende-se aí a preocupação de Jobim com o ensino, em razão dos conflitos enfrentados muito antes do surgimento do curso - e que, ironicamente, persistem ainda hoje. Desde 1918, quando a Associação Brasileira de Imprensa (ABI) discutiu no Primeiro Congresso de Jornalistas a criação de uma escola de jornalismo, criou-se um conflito entre os profissionais que atuavam na área. Muitos acreditavam que o "jornalista já nasce pronto", outros eram defensores de um ensino que pudesse qualificar e aumentar o nível de conhecimento do profissional antes que ele ingressasse no mercado.

Embora o processo de industrialização já estivesse em andamento nas empresas jornalísticas no início do século XX, a função de jornalista ainda era exercida como um "bico", geralmente por intelectuais que queriam tornar público seus trabalhos ou por jornalistas sem formação específica que se dividiam em mais de um emprego, principalmente entre o jornal e o funcionalismo público. 
Mas muitos lutavam pela valorização do profissional como forma de melhorar a qualidade da imprensa. Por isso, outras iniciativas surgiram. Uma das mais significativas foi a da criação do curso de Jornalismo da Universidade do Distrito Federal, idealizada por Anísio Teixeira, no Rio de Janeiro, e criada por Decreto do prefeito Pedro Ernesto. A Cátedra, entregue ao jornalista Costa Rego, secretário de redação do jornal Correio da Manhã, "um dos principais formadores de opinião pública no país" (MARQUES DE MELO, 2003a, p.295), diferia da proposta da ABI, já que não pretendia formar profissionais de nível superior, mas intelectuais que pudessem "refletir sobre o fenômeno ascendente da cultura de massa, correlacionando duas atividades então imbricadas profissionalmente: o jornalismo e a publicidade".

A iniciativa de Anísio Teixeira foi desativada em 1939 pelo governo autoritário de Getúlio Vargas. A elite hegemônica encarava aquela Universidade como sendo um "núcleo de perigosos esquerdistas, a esse título recebendo a hostilidade simultânea dos meios católicos e integralistas (que, a essa altura, diga-se de passagem, mal se distinguiam um do outro)" (MARTINS apud MARQUES DE MELO, 2003a, p.302).

Enquanto isso, na primeira metade do século passado, mesmo com rejeição a mudanças, a imprensa entrava na fase que Bahia (1990) e Sodré (1999) chamavam de industrial, idéia contestada por Lins da Silva (1991), porque faltavam condições na economia local para sustentar essa vontade de fazer do jornal um negócio. Mas a fase era de 
desenvolvimento, com o surgimento de novos jornais e o fortalecimento de alguns que permanecem até hoje, chamada "grande imprensa".

Contudo uma reforma maior ainda estava por vir. Durante a Segunda Guerra Mundial, os jornais puderam conhecer um novo formato na maneira de escrever, assimilada dos jornalistas estrangeiros, principalmente norte-americanos, graças às agências de notícias internacionais que enviavam seus telegramas numa linguagem que diferia do então jornalismo praticado no Brasil. Até então, os textos eram "caudalosos e plenos de literatices", com matérias adjetivadas que demoram a introduzir o fato e abertas com enormes "narizes de cera" (GENTILLI, 2002). "Os homens de letras buscavam encontrar no jornal o que não encontravam no livro: notoriedade, em primeiro lugar; um pouco de dinheiro, se possível" (SODRÉ, 1999, p.292). Embora o tema político fosse destaque nos jornais, ainda assim ele não conseguia neutralizar a influência literária na linguagem.

Pois é exatamente no período da guerra que os jornalistas brasileiros vivenciam experiências no exterior, principalmente nos Estados Unidos, e conhecem o lead, a pirâmide invertida e outras técnicas que davam ao jornalismo um estilo próprio. Lins da Silva (1991, p.72) lembra que alguns que visitaram a emergente potência no final do século XIX "com certeza se deixaram influenciar não apenas pelas idéias políticas correntes naquele país, como também pela sua imprensa”, caso de Rui Barbosa, Quintino Bacaiúva e José do Patrocínio. 
Mas a influência norte-americana na imprensa brasileira só veio com Pompeu de Souza e Danton Jobim, então secretário e diretor de redação do Diário Carioca, respectivamente, que provocaram uma "limpeza" na redação do jornal. Trazendo novos talentos oriundos de cursos universitários, eles formaram uma nova geração de jornalistas, aplicando as técnicas que aprenderam durante suas experiências nos Estados Unidos. Elas iriam se refletir no ensino, já que, ao mesmo tempo, começavam a surgir as primeiras escolas de nível superior.

Poucos anos antes, Vitorino Prata Castelo Branco havia promovido uma série de palestras e conferências na sede da Associação dos Profissionais de Imprensa de São Paulo, que culminaram no primeiro Curso Livre de Jornalismo no Brasil (DIAS, 2004). Achincalhado por jornalistas e criticado até mesmo pelo Sindicato da categoria, Castelo Branco abandonou o projeto e o jornalismo, voltando a atuar como advogado.

Na mesma conjuntura Cásper Líbero explicitou seu sonho de criar uma escola de jornalismo. Ele deixou, em testamento, seu desejo de criar uma escola que formasse profissionais mais capacitados, o que se tornou realidade em 1947, com o surgimento da Escola Cásper Líbero, vinculada à Faculdade de Filosofia da Pontifícia Universidade Católica de São Paulo - PUC-SP. A sua criação só foi possível graças à autorização para o funcionamento do curso que seria ministrado pela Faculdade Nacional de Filosofia da Universidade do Brasil, com a cooperação da Associação 
Brasileira de Imprensa e dos sindicatos representativos das categorias de empregados e de empregadores das empresas jornalísticas.

O curso da Universidade do Brasil, atual Universidade Federal do Rio de Janeiro, só começou a funcionar em 1948, tendo Danton Jobim como responsável pela cadeira de Jornalismo. Daí sua preocupação com o ensino e com o profissional que a escolas iria formar. A intenção de que o curso fosse elaborado com o apoio do Sindicato e das empresas jornalísticas foi por água abaixo. Ainda continuava sendo forte a rejeição a esse tipo de iniciativa, principalmente por parte dos profissionais mais antigos.

\section{A discussão sobre o currículo}

A rejeição do mercado trazia à tona discussões acerca do currículo e do foco do ensino, provocando divergências sobre a questão técnica e a formação humanística que deveria ser dada ao estudante.

Embora reconhecendo a necessidade e as deficiências existentes na parte técnica do curso da Universidade do Brasil, Jobim apontava a falta de compreensão dos próprios alunos, que acreditavam ser esta a parte essencial do curso, queixando-se do excesso da parte acadêmica.

Retrucava que, embora não se tivesse encontrado ainda o modelo ideal - o currículo sofria alteração a cada ano -, o curso não poderia ser 
considerado meramente uma formação de práticos em jornalismo, mas deveria, sim, dar os conhecimentos necessários para que o profissional pudesse exercer sua profissão com uma cultura universitária. Justificava sua preocupação citando o problema do ensino secundário, onde matérias básicas para o desempenho jornalístico - como português, história, geografia e literatura - eram deficientemente ensinadas.

Posição diferente da de Jobim tinha Carlos Rizzini, também professor da Universidade do Brasil, antes de dirigir a Escola Cásper Líbero. Para ele, o ensino do jornalismo deveria ser pautado pelo modelo norte-americano da Escola de Jornalismo de Missouri, onde os alunos não apenas aprendiam a fazer jornalismo, como o faziam de fato, por meio da publicação diária do University Missourian, jornal que eles redigiam. O ensino prático deveria ser prioridade.

Embora reconhecendo a impossibilidade de se criar um curso dentro do mesmo modelo, principalmente em razão das questões financeiras que impediam as escolas do país de sustentar tal projeto, Rizzini acreditava que o modelo brasileiro, principalmente o estabelecido na Universidade do Brasil, tinha graves defeitos. O maior deles era o de "serem culturais e não profissionais os grupos eletivos de especialização". Depois dos dois anos básicos, Rizzini (1953, p.51) propunha o terceiro ano apenas de especialização profissional. Sugeria, por exemplo, que a cadeira Técnica de Jornal, oferecida nos dois primeiros anos básicos, fosse mudada para cadeira de Redação e Reportagem, onde se dividiria entre Redação e Secretaria no primeiro ano e Reportagem e Entrevista no 
segundo ano, "estudadas separadamente como se fossem disciplinas autônomas".

Para ele, no estudo teórico e prático de redação entrariam:

editoriais, comentários, tópicos, cabeças, notas, crônicas e resumos, cuja variedade é infinita, indo desde o artigo de fundo e a colaboração assinada até a crônica de cinema, esportiva ou mundana, e ainda traduções e utilização da correspondência e do serviço telegráfico. (RIZZINI, 1953, p. 51-52)

$\mathrm{Na}$ parte de secretaria entrariam todas as tarefas pertinentes ao secretário de redação, como seleção de textos, distribuição de tarefas, espelho de paginação, entre outras. A reportagem seria destinada à "coleta normal de notas", de dados e à cobertura de acontecimentos esperados, incluindo também a busca de históricos e a narrativa de situações. A entrevista, considerada por ele como uma das mais difíceis formas de jornalismo, deveria ser ensinada como a arte de "saber perguntar e ouvir, e de saber transmitir opiniões e depoimentos". Rizzini ainda acreditava que ninguém aprenderia a fazer reportagens ou entrevistas se não as fizessem na prática e não as publicassem depois.

Outras propostas de Rizzini eram: restringir a cadeira de Língua Portuguesa e Literatura de Língua Portuguesa ${ }^{1}$ somente à parte de literatura no primeiro ano e substituí-la, no segundo, por História da Literatura Brasileira, especialmente no campo do jornalismo. Além disso, propunha restringir o ensino de História do Brasil e História Contemporânea aos últimos sessenta anos e incluir na disciplina de 
Administração o ensino de Fotografia, Gravura e Artes Gráficas, enquanto não fossem criadas essas disciplinas específicas.

É certo que o ensino do jornalismo não pode ser feito sem o entendimento dos problemas da atualidade. De forma nenhuma ele pode ser apartado da realidade e, por isso, é imprescindível que o estudante conheça e vivencie os problemas sociais contemporâneos. Como explicou Beltrão, em palestra no IV Seminário Internacional do Ciespal, realizado no Rio de Janeiro:

\begin{abstract}
Su estúdio, como su prática, exige uma participación social y directa del individio, no solamente em trabajos didácticos sino también em los sentimientos y actividades de su época (momento histórico) y de su gente (comunidad). Hay que emplear métodos actualizados, mediante los cuales el estudiante vaya paulatinamente estructurando sus ideales, actitudes e intereses mentalmente, por emoción y por participación, em uma especie de totalitarismo educacional. (BELTRÃO In: CIESPAL, 1965, p.350)
\end{abstract}

No entanto, o ensino do jornalismo não pode ser visto apenas a partir de uma visão contemporânea de mundo, mas a partir do entendimento da formação da sociedade e da cultura, numa visão muito mais universal.

Sob o ponto de vista do ensino na atualidade, essas propostas de Rizzini parecem insuficientes. Mas é preciso entender que naquele momento a grande crítica que ele fazia ao curso de jornalismo da

\footnotetext{
${ }^{1} \mathrm{O}$ interessante nesta proposta é que atualmente grande número de alunos das escolas de jornalismo particulares, onde o exame vestibular exige menos, queixam-se da ausência da língua portuguesa no currículo, já que o ensino médio se mostra deficiente no ensino dessa disciplina.
} 
Faculdade de Filosofia da Universidade do Brasil se dava em razão da falta de treino profissional, preocupação compartilhada também por Jobim.

O próprio diretor da Associação Brasileira de Imprensa à época, Fernando Segismundo (In: CIESPAL, 1965, p.126), também em seminário do Ciespal, explicava que as escolas brasileiras não correspondiam às necessidades dos meios de comunicação. Aos seus formandos eram dadas tarefas secundárias nas redações, anteriormente concedidas aos colaboradores literários, para as quais eram considerados os conhecimentos e a cultura adquiridos em um curso superior. Nas tarefas de jornalismo, propriamente ditas, esses egressos das universidades eram colocados em um plano subalterno aos jornalistas que não tinham formação acadêmica, já que nesse caso considerava-se que era importante e decisiva "a capacidade de fazer e não a mera informação de como fazer".

Porém Rizzini ia além, afirmando ser um absurdo "pretender-se um ensino jornalístico que não seja, acima de tudo, um ensino profissional", posição diferente da de Jobim, que, assim como Groth, entendia o fenômeno do jornalismo como uma questão cultural muito mais ampla, que deveria ser mais bem estudada. Nesse sentido, Jobim não via o ensino de jornalismo apenas como uma questão de técnica, mas dentro de uma conjuntura muito maior, propiciada pela universidade e amparada em um tripé moral, cultural e técnico, que não deveria ser esquecido nem mesmo dentro das chamadas disciplinas especializadas. Além disso, ainda havia a preocupação com o perfil do estudante. Como citado anteriormente, ele 
teria as falhas que poderiam existir na formação desse aluno antes do ingresso na universidade, advindas do ensino secundário.

E embora o agora chamado ensino médio tenha piorado - e muito na maior parte das escolas, principalmente as públicas, da década de 50 para cá, as mesmas discussões se apresentam hoje sobre o currículo do curso de Jornalismo, que, desde o final da década de 60 , se tornou uma habilitação do curso de Comunicação Social.

Geralmente, uma das soluções apontadas para resolver o impasse de um curso deficiente é a mudança na grade curricular. Sem dúvida, o conteúdo curricular tem muita importância. Mas, pesquisadores como Marques de Melo (1979, p.39) acreditam que a mudança de currículo, sempre apontada como uma solução eficiente, é ineficaz, pois "os currículos constituem apenas uma variável secundária da questão principal, que é a própria estrutura do ensino brasileiro e seus fundamentos sociais e ideológicos”. Dessa forma, o problema do ensino do jornalismo não é isolado, mas faz parte de uma "inadequação do sistema de ensino superior vigente no país". Para ele, não basta mudar os currículos sem uma reforma nas estruturas universitárias criadas para atender às elites do passado e que não atendem mais nem mesmo ao setor progressivo da burguesia. Mesmo porque essas reformas curriculares normalmente ocorrem de forma autoritária, ignorando as necessidades do mercado e dos alunos e priorizando os interesses dos professores de maior titulação dentro das escolas. 
Marques de Melo (1979, p. 39) propõe uma reformulação completa do sistema educacional brasileiro, que não depende de grupos isolados, como os de docentes ou de alunos, mas de uma união em torno de propostas que possam adaptar o ensino "às necessidades de um desenvolvimento sócio-econômico autônomo e democratizante, de um desenvolvimento cultural fiel aos valores populares da nação".

\section{A prática acadêmica}

Independente dessa grande reforma proposta, muitos são os problemas que se apresentam quando se pretende analisar o que acontece nas escolas de jornalismo do país. Um deles é a própria prática acadêmica. Ao professor cabe a aplicação e a reforma dos métodos pedagógicos, estimulando a participação do aluno em sala de aula, em bibliotecas e em laboratórios. Se no início do curso faltavam livros e instalações necessários ao ensino do jornalismo, hoje esses recursos estão disponíveis nas universidades, mesmo que em menor grau nas escolas criadas do dia para a noite nos centros urbanos brasileiros. Incentivar a pesquisa deve ser um atributo presente em cada docente, estimulando o estudante para a busca de novos conhecimentos. Este seria um ponto inicial no processo de romper as barreiras entre o ensino teórico e o tecnicista, envolvendo o aluno em pesquisas aplicadas e teóricas, que proporcionariam uma formação mais rica, crítica e ética. 
Como explica Santos (2003, p.69):

É talvez na aplicação do currículo que pode estar o "pulo do
gato". De nada adianta termos disciplinas de formação geral e
específica, além da técnica, mesmo que distribuídas
equilibradamente ao longo do curso. A dificuldade do aluno
continua. A sensação que fica, para os professores, é que ele
entendeu os conceitos da sua disciplina, mas isso não o ajuda
na reflexão sobre a técnica, que fica apartada, e vice-versa.
Aliás, muitas vezes ele nem sabe o porquê de estar assistindo
determinada disciplina.

Como visto, o ensino de jornalismo não é apenas uma questão de currículo, mas principalmente uma análise de sua aplicação, de como estimular o aluno à reflexão e de como coordenar a participação de todos os envolvidos: instituição, aluno e professor.

Jobim, como professor de jornalismo, desde o final da década de 40 já levantava essas questões que ainda hoje discutimos. Seu curso de pedagogia do jornalismo no Ciespal discutia tanto os perfis dos professores quanto dos alunos, além de métodos de ensino.

Este trabalho pretende abordar a pedagogia do jornalismo proposta por Danton Jobim durante o período de docência na Universidade do Brasil, atual Universidade Federal do Rio de Janeiro, e também como responsável pela cátedra de Metodologia de Ensino de Jornalismo no Centro de Estudos Superiores de Jornalismo da América Latina - Ciespal, como professor visitante na Universidade do Texas, onde ministrou seminários sobre Jornalismo Mundial Comparado, e como convidado na Universidade de Paris, onde proferiu conferências sobre o tema Introdução ao Jornalismo Contemporâneo. 
Além disso, abordaremos a experiência vivenciada por Jobim quando, a partir do final da década de 40, como já nos referimos anteriormente, foi um dos responsáveis pela escola de jornalismo que funcionou dentro da redação do jornal Diário Carioca, onde atuou por 33 anos. Inicialmente como redator político e depois como secretário e diretor de redação, Jobim, junto com Pompeu de Souza e Luís Paulistano, formou uma geração inteira de profissionais com uma visão diferente do jornalismo até então praticado. Seu grupo foi o responsável pela revolução no jornalismo brasileiro, introduzindo as técnicas de jornalismo procedentes dos Estados Unidos.

O pensamento jornalístico de Danton Jobim pode ser traduzido em uma palavra: simplicidade. Sua luta era por uma linguagem jornalística que pudesse ser bem compreendida por todos. Por isso, e por toda sua contribuição ao jornalismo — seja como repórter ou como articulista, seja como professor ou como político —-, é que Jobim tem um lugar de destaque dentro da história do jornalismo brasileiro.

Nesse sentido é que este trabalho teve como objetivo analisar a contribuição de Danton Jobim para o desenvolvimento de uma pedagogia do jornalismo no Brasil. Para isso, pretendeu-se identificar e contextualizar as modificações nos processos jornalísticos efetuadas por Danton Jobim e sua equipe na redação do Diário Carioca, sob a influência do modelo norte-americano - que resultaram numa reforma total da imprensa brasileira no pós-guerra. Da mesma forma, buscou-se identificar as estratégias e fontes de referência de Danton Jobim, através da análise de 
sua proposta de pedagogia para o jornalismo, verificando de que forma essa proposta se relacionava e dialogava com os modelos humanista europeu e pragmático norte-americano vigentes à época e como a articulação desses dois modelos foi adaptada à realidade brasileira naquele período.

O resgate da memória de Danton Jobim passa, necessariamente, pela avaliação de sua importância no desenvolvimento de uma pedagogia do jornalismo no Brasil. Nesse sentido, é fundamental a tentativa de identificar aspectos relevantes tanto de sua prática jornalística quanto de suas proposta e prática pedagógicas, a fim de confrontá-las com os modelos vigentes à época, numa busca por evidências de rupturas e/ou continuidades. Para tanto, serão realizadas análises de textos e entrevistas não estruturadas.

Num primeiro momento, pretendeu-se realizar uma análise nos textos de Danton Jobim, tendo como principal referência os seus dois livros de maior relevância sobre o tema - Espírito do Jornalismo e Pedagogia Del Periodismo -, buscando reunir elementos para identificar as propostas elaboradas e as modificações introduzidas.

Neste trabalho, partimos do pressuposto de que pedagogia é um conjunto de princípios que dão suporte à definição de teorias, métodos e metodologias do processo educacional, que podem ser considerados mais eficientes para se alcançar o ideal da educação, que é a aprendizagem. Aceitamos como base teórica de comparação o instrumentalismo pragmático deweyano, cujo foco está centrado no conceito de 
continuidade e democracia dentro do ensino - e para quem a educação é uma função social ligada aos objetivos da sociedade. Dewey defendia que "toda experiência implica pensamento; não se trata apenas de verificação social, mas de percepção consciente das relações e de reciprocidade entre indivíduo e entorno" (BELTRÁN, 2003, p.50). Dessa forma, suas orientações educativas estavam centradas na continuidade entre natureza e experiência humana, e no desenvolvimento dessa aprendizagem através da interação social que ocorre por meio da comunicação. Utilizamos essa base de comparação em razão de Jobim, da mesma forma, afirmar que sua prática pedagógica no jornalismo estava centrada na observação empírica e voltada para o "ensinar a aprender", percebendo que era preciso preparar o aluno para a continuidade do aprendizado além dos muros da escola, a partir de sua experiência nas redações e na sociedade.

A necessidade de inserir a análise em um contexto nacional leva à conveniência de uma comparação adicional com um paradigma brasileiro, que escolhemos ser Anísio Teixeira, pois ele adaptou o modelo deweyano à nossa realidade, na década de 1920, chegando a ter seu trabalho rotulado como americanista (CARVALHO, 2000). Além disso, construiu uma interpretação da Filosofia e da Filosofia da Educação do pensador norte-americano e difundiu-a no Brasil. O autor brasileiro parte do conceito de experiência de Dewey nas correntes da filosofia que fundamentaram as teorias educacionais, assim como de sua vinculação à educação e à organização da escola com o meio social, para formular uma "nova" Filosofia e Teoria da Educação. Para ele, experiência poderia ser 
conceituada a partir das relações entre os variados tipos de elementos existentes no universo, que os obrigariam a uma constante transformação, fazendo com que a ação e a reação entre os corpos ou organismos (já que não seria um atributo puramente humano) promovessem uma modificação em ambos.

Procurando contextualizar o ensino e sua relação com a prática do processo jornalístico daquela época, também realizou-se uma investigação histórica do jornalismo brasileiro de então, baseada nas obras de Nelson Werneck Sodré, Juarez Bahia, Alzira Alves de Abreu, José Marques de Melo e Victor Gentilli, entre outros pesquisadores da história do jornalismo no Brasil.

No entanto, existem poucos registros sobre Danton Jobim e sua importante passagem pela universidade e pelo jornalismo brasileiros. Sobre isso, Barbosa Lima Sobrinho (1978) escreveu:

\begin{abstract}
Modesto, despreocupado, indiferente, Danton Jobim nunca falava nesses altos títulos que conquistara. Parece mesmo que Ihes não dava importância. Muitas e muitas vezes Ihe sugeri que escrevesse as suas memórias. Poderia ter um título que já me parecia adequado: Memórias dos Bastidores. Porque conhecia os acontecimentos políticos por dentro, por detrás das ribaltas, participando de muitos deles com a sua inteligência e a sua capacidade de expressão. Mas era difícil vencer a sua convicção de que tudo era efêmero e inútil e que Ihe bastava a convicção de haver atravessado a vida com o sentimento de profunda dignidade, que emana de seus exemplos e de sua tranqüila doutrinação.
\end{abstract}

Num esforço para superar essa lacuna, trabalhamos com entrevistas não-estruturadas e depoimentos de jornalistas, amigos e 
alunos de Danton Jobim, que acompanharam sua trajetória na imprensa e na universidade, seguindo o modelo proposto pela pesquisadora inglesa Sue Stone (1984, p. 17-19), que sugere que esse tipo de entrevista "apresenta melhores resultados em contextos onde o pesquisador se aprofunda na vida e cultura de um determinado grupo de pessoas, de modo a entender suas necessidades e comportamento". Dessa forma, é possível permitir ao "entrevistado apresentar seus próprios pontos de vista, sem ser dominado pelo padrão de referências do pesquisador". Nessa forma de entrevista não-estruturada podem surgir pontos, não previstos antecipadamente pelo entrevistador, de alta relevância para o estudo, além de, através do diálogo, ser possível expandir a compreensão sobre o modo de pensar do entrevistado.

A respeito da utilização da entrevista no resgate da história de Danton Jobim, utilizaremos os métodos propostos pela pesquisadora Verena Alberti (2004, p19), no livro "Manual de História Oral”, que explica:

Trata-se de ampliar o conhecimento sobre acontecimentos e conjunturas do passado através do estudo aprofundado de experiências e visões particulares; de compreender a sociedade através do indivíduo que nela viveu; de estabelecer relações entre o geral e o particular através da análise comparativa de diferentes testemunhos, e de tomar as formas como o passado é apreendido e interpretado por indivíduos e grupos como dado objetivo para compreender suas ações.

As fontes utilizadas estão ligadas à trajetória do jornalista no Diário Carioca, na Universidade do Brasil e na Associação Brasileira de Imprensa, durante sua gestão à frente daquela instituição. Isso porque, 
nas palavras do próprio Danton Jobim (1964, p.52), "jamais deixei de conceber a cátedra de jornalismo como uma prolongação de minha atividade profissional". Partindo dessa declaração, pretendemos analisar essa afirmação, verificando a continuidade de suas idéias e experiências no jornalismo nas atividades de professor e pedagogo.

Assim, para entender a proposta pedagógica de Danton Jobim, partimos de sua trajetória profissional multifacetada. No jornalismo, atuou como redator de diferentes jornais, articulista, analista político, editorialista, além de diretor de redação. Na Associação Brasileira de Imprensa foi presidente, atuando fortemente na defesa de profissionais ameaçados pela ditadura militar. Como senador da República, também se destacou na luta pela liberdade de imprensa.

Com isso, defende-se a hipótese de que essa vivência de Jobim que muitas vezes se confundiu, mas jamais se separou dos propósitos jornalísticos de ética e de serviço público - foi o que contribuiu para o seu modelo de ensino do jornalismo, influenciado tanto pelo modelo norteamericano $^{2}$, mas sem se distanciar do modelo humanista europeu, principalmente o francês. Assim, defendia a introdução de técnicas jornalísticas mais eficientes, no sentido de se comunicar com mais facilidade com o leitor, ao mesmo tempo em que afirmava que o jornalista necessitava de um amplo conhecimento humanístico para fazer do jornalismo um instrumento a favor da sociedade.

\footnotetext{
${ }^{2}$ Modelo que Marques de Melo (1991, p.34) define como sendo de "indústria/ensino de comunicação de massa”.
} 
O ensino de jornalismo no Brasil tem pouco mais de meio século. Surgiu em razão das "demandas sociais emergentes nas empresas jornalísticas" que, em razão do processo de reestruturação industrial por que passavam, reclamavam profissionais qualificados e em sintonia com a renovação que se apresentava na imprensa brasileira do pós-guerra (MARQUES DE MELO, 1991).

No entanto, faltava sintonia entre as escolas e as empresas, e o modelo de ensino proposto não agradava nem aos alunos, nem aos professores e muito menos às empresas jornalísticas. Mas quais os problemas identificados no curso e quais eram as alternativas propostas? O primeiro grande problema era estrutural (MARQUES DE MELO, 1991, p.13-14). Embora tivesse a finalidade de formar jornalistas, o curso não era independente e estava submetido às decisões das faculdades de filosofia das quais faziam parte.

Depois, não havia entrosamento entre as disciplinas, muito menos entre as práticas e as teóricas. Ainda havia o problema do corpo docente. Em um momento em que os profissionais qualificados da imprensa não detinham títulos acadêmicos, os mestres vinham de outras áreas do conhecimento, provocando uma barreira entre o saber universitário e a prática profissional, reproduzindo o mesmo modelo de criação da universidade no Brasil, voltada às elites e centrada em si própria, sem uma preocupação com o meio social.

Na Universidade do Brasil, Danton Jobim insistia na autonomia do curso de jornalismo e questionava as práticas pedagógicas autoritárias 
existentes, lutando por um modelo que integrasse a prática e a teoria para formar jornalistas cultural e eticamente capazes, sem dissociá-las uma da outra, pelo contrário. Para ele, a escola deveria ser o grande agente da transmissão e distribuição intelectuais, mas colocando "toda espécie de informação a serviço do homem, contribuindo para seu aperfeiçoamento moral".

Mas a questão do ensino do jornalismo até os dias atuais permanece em um impasse que não conseguiu obter êxito na sua resolução. Por isso, nos voltamos para as propostas de Jobim, esquecidas com o decorrer do tempo, em busca de respostas para questões ainda pendentes, apontando para um modelo de ensino no qual o mais importante não é apenas ensinar, mas "ensinar a aprender".

Um aprofundamento e resgate de sua obra são também importantes, neste momento, como forma de homenagem ao centenário de nascimento de Danton Jobim, que ocorreu em 2006. 


\section{0 ensino do Jornalismo no Brasil: das iniciativas pioneiras ao curso na Universidade do Brasil}

Se a educação superior oficial no Brasil foi criada tardiamente 1808 foi o ano da instalação da primeira escola superior - , no caso das escolas superiores de Jornalismo, a demora foi maior ainda: somente em 1947, 139 anos após, surgiu o primeiro curso oficial na Fundação Cásper Líbero.

Até então, os jornalistas que entravam nas redações eram, em sua maioria, oriundos dos cursos de Direito, já existentes desde o ano de 1827.

\footnotetext{
Nesse ano de 1827, instalam-se os cursos jurídicos de São Paulo e do Recife. Um acontecimento que a história do Império e da República vai anotar como sinal de novos quadros políticos e culturais no processo do desenvolvimento brasileiro. Das duas escolas de Direito sairão agitadores, líderes, pensadores, estadistas e jornalistas. (BAHIA, 1990, p. 41-42)
}

$\mathrm{Na}$ verdade, dessas escolas saíram jornalistas ilustres e reconhecidos. Esse foi o caso dos consagrados Barbosa Lima Sobrinho, Rui Barbosa e Alceu Amoroso Lima, entre outros.

Mas, desde 1821, com a volta da Corte para Portugal, os jornais já circulavam livremente. Anteriores a essa data, circularam A Gazeta do Rio de Janeiro, uma espécie de jornal oficial da Corte Portuguesa, e o Correio 
Braziliense, jornal feito em Londres por Hipólito da Costa, com circulação clandestina no Brasil. Após a liberação da imprensa, o número de jornais cresceu rapidamente. $E$, na primeira metade do século $X X$, os grandes jornais do Rio e de São Paulo já se renovavam tecnicamente com o apoio da publicidade. Para Bahia (1990, p. 208), a partir da década de 30, a imprensa se expandiu com a criação de "uma indústria cultural de identidade própria”.

O trabalho jornalístico também se organizava nos anos 30. Laurenti (2002, p. 142) explica que "em 30 de novembro de 1938, o Decreto-lei $n^{\circ}$ 910 dispôs sobre a duração e condições do trabalho em empresas jornalísticas".

Entende-se como jornalista o trabalhador intelectual cuja função se estende desde a busca de informação até a redação de notícias e artigos e à organização e direção desse trabalho. (Decreto-lei n. 910. In: BOBBIO, 1938, p. 533)

Mas a idéia de uma escola superior de jornalismo no Brasil não progredia, embora na vizinha Argentina o curso já funcionasse desde 1934 (MARQUES DE MELO, 2003a). Na Europa, já havia surgido na França, em 1899, a Escola Superior de Jornalismo de Paris, enquanto, em 1903, a Universidade de Zürich estabelecia um curso permanente, motivada pelas conferências do professor Karl Bucher sobre "ciências da imprensa" na Universidade de Besle (Suiça), entre 1884 e 1890 (MARQUES DE MELO, 2005). O mesmo Bucher, indo para a Alemanha, cria, em 1916, o primeiro instituto universitário de ciência da imprensa na Universidade de Leipzig. 
A criação de um curso de Jornalismo também era uma aspiração antiga de Gustavo de Lacerda, fundador da Associação de Imprensa, hoje Associação Brasileira de Imprensa (ABI). Na fundação da entidade, a nota publicada pelo jornal O Paiz, do Rio de Janeiro, de 9 de abril de 1908, especificava sua finalidade:

Está fundada nesta capital, a contar de 7 do corrente, a Associação de Imprensa, tendo por fins principais:

Criar e manter uma caixa de pensões e auxílios para os sócios e suas famílias; manter um serviço de assistência médica e farmacêutica; instalar o Retiro da Imprensa, com enfermaria e residência para velhos e enfermos; manter, no centro da cidade, a sede social, com biblioteca, salões de conferências e diversões etc; habilitar, por meio de título de capacidade intelectual e moral, o pretendente à colocação no jornalismo ${ }^{3}$; prestar pública homenagem a Guttenberg, o fundador da imprensa, por meio de uma festa anual, para a qual procurará associar o Governo da República.

A Associação de Imprensa publicará um anuário da mesma, com o nome e idade de todos os sócios, detalhes de todos interesses sobre artes, ciências e letras, e instituirá a carteira de jornalista, como atestado de identidade e recomendação do portador. A primeira diretoria compõe-se dos srs. Gustavo de Lacerda (presidente), Francisco Souto, Luís Honório, Arthur Marques, Alberto Seabra e Alberico Doemon.

Da administração farão parte, ainda, as comissões que serão nomeadas brevemente e são as seguintes:

De Organização do Anuário, de Propaganda de Festas e de Economia e Finanças e de Auxílios e Assistência. (Apud MOREL In: Boletim da ABI, abril de 1978, p.16)

Para Morel (1978), algumas reivindicações, como a de "habilitar por meio de título de capacidade intelectual o pretendente à colocação no jornalismo, não deixam de ser a base dos atuais cursos de Jornalismo".

\footnotetext{
${ }^{3}$ Grifo da autora.
} 
Mas essas reivindicações só serão alcançadas bem mais adiante, com o advento da Revolução de 1930.

Em 1918, a Associação Brasileira de Imprensa, no seu Primeiro Congresso de Jornalistas, tentou criar aquela que seria a primeira Escola de Jornalismo no país, baseada nos moldes das organizações norteamericanas. Durante o Congresso foram oficializadas as propostas de criação de um curso de Jornalismo, descritas por Victor de Sá (1955) da seguinte forma:

\begin{abstract}
Segundo o regulamento estabelecido para a Escola de Jornalismo, onde havia idéias colhidas nas organizações norteamericanas, o curso geral seria de três anos, além de um curso vestibular de dois anos que são de preparo para a matrícula no instituto. (....) A escola de Jornalismo, que não queria ser oficial, que não faria doutores nem bacharéis, mas que se propunha unicamente a propinar a seus alunos o ensino de matérias julgadas essenciais à prática da profissão cuidando da cabeça e das mãos dos estudantes, com a teoria da ciência necessária e a prática das artes de gravar. Ao lado do programa das aulas do curso teórico propriamente dito, a Escola ministraria o ensino prático. Seria, então, fundado o jornal para os alunos e na redação e nas oficinas dessa folha iriam os estudantes desenvolver praticamente a sua força na sintaxe e na ortografia da língua. O jornal seria a escola de aplicação, onde os alunos completariam os seus estudos, redigindo reportagens, que poderiam ser mundanas, artísticas, policiais ou sociais, escrevendo artigos de política e finanças, com orientação própria ou ditada pelo professor, fazendo a crítica de música, pintura, teatro e letras, conforme o adiantamento no Curso regular da Escola. (SÁ apud MARQUES DE MELO, 1974, p.16)
\end{abstract}

A preocupação da entidade era com o preparo dos profissionais do jornalismo. Em um momento em que a sociedade se transformava rapidamente e a imprensa evoluía para uma fase industrial, principalmente nas maiores capitais do país, a idéia de formar quadros responsáveis na 
área de jornalismo foi tomando corpo, ainda que contasse com considerável rejeição por boa parte da categoria.

\subsection{Experiências pioneiras}

Embora nada fosse em frente, muitas iniciativas eram tomadas em prol de um curso de Jornalismo. Foi o caso de Vitorino Prata Castelo Branco que, de acordo com Kobayashi (2003), deixou como grande legado a sistematização do "ensino de jornalismo de maneira que todas as pessoas tivessem a oportunidade de aprender essa profissão". A autora lembra que "acusado de leviano, oportunista, ele teve o mérito de difundir também o ensino a distância, numa época sem computadores ou Internet, por exemplo".

Castelo Branco, além de jornalista, foi advogado, professor e empresário. Nascido em Itirapina, São Paulo, em 1904, formou-se em Direito na Universidade Federal Fluminense, em 1956, e, em 1958, já concluía seu doutorado na Universidade de São Paulo. Lecionou na Faculdade de Direito de Guarulhos (SP), na Faculdade de Administração de São Paulo e na Sociedade Brasileira de Direito. Mas sua ligação com o jornalismo era anterior.

No final de 1942, já escrevendo para jornais de São Paulo, decide se aperfeiçoar e vai para a Argentina participar de um curso na Sociedad Argentina de Periodismo y Redacción, onde recebe o certificado com 
distinção. Lá, tem contato com o Círculo de Periodistas de la Província de Buenos Aires e com a Escola Argentina de Periodismo, da Universidad Nacional de la Plata. Segundo Dias (2004):

\begin{abstract}
Ali, conhece a estrutura da Escola de Periodismo e seus antecedentes, seu primeiro plano de estudos, o regulamento e o início de seus cursos, em 1935. Com a mente repleta de ideais, volta ao Brasil com muito entusiasmo e decide criar um curso de Jornalismo.
\end{abstract}

Dias (2004) explica que, no ano seguinte, em 1943, Castelo Branco inicia uma série de palestras e conferências na sede da Associação dos Profissionais de Imprensa de São Paulo, que culminaram no primeiro Curso Livre de Jornalismo no Brasil.

Lançar um Curso de Jornalismo numa época em que não existiam escolas de Comunicação no Brasil foi uma tarefa pioneira, mas penosa. Marques de Melo (1974, p.18) conta que o "curso não foi muito bem recebido pelo Sindicato dos Jornalistas, que encaminhou publicamente uma representação ao diretor Geral do DIP”.

O motivo de maior resistência do Sindicato e dos empresários de comunicação daquela época foi o curso de jornalismo ter se transformado em ensino a distância, vendido em fascículos por meio de uma revista.

Os cursos eram parte integrante da revista mensal intitulada "Cursos". A publicação se autodenominava uma revista de ensino prático. Nela não eram veiculados anúncios de qualquer espécie. Castelo Branco acreditava que estes não se enquadravam no propósito da revista, que era a educação a distância. 
Cabe frisar, que antes do lançamento do curso de jornalismo, a revista já circulava por todo o país sem causar qualquer tipo de espanto. A revista estava, legalmente, registrada como tal e, além dos assinantes, podia inserir anúncios, publicar matéria remunerada e gozar, enfim, de todas as regalias e prerrogativas dessa classificação. (KOBAYASHI, 2003)

Embora Castelo Branco tenha sido pioneiro também no ensino a distância, sua maior contribuição foi na sistematização do ensino do Jornalismo. Kobayashi (2004) acredita que ele desafiou todos que viam a profissão apenas como um "bico". "Fez com que as pessoas saíssem de uma situação confortável onde todos já nasciam jornalistas”.

Marques de Melo $(1974,18)$ lembra que sua iniciativa desencadeou uma "série de cursos livres de jornalismo que viriam a existir em várias cidades brasileiras, paralelamente aos cursos regulares e, até mesmo, como um desafio a eles".

Mas ele contribuiu principalmente trazendo à tona as antigas discussões sobre a necessidade da formação acadêmica do jornalista, que se fazem ainda muito atuais nos dias de hoje.

Se se exige diploma de quase todas as profissões, por que não se exige, também, um título do homem que deseja trabalhar na imprensa, escrevendo em jornais, opinando sôbre questões transcendentes da nacionalidade, discutindo os assuntos mais técnicos, propagando as idéias mais ousadas? (CASTELO BRANCO apud KOBAYASHI, 2004)

Antes disso, em 1935, ao criar a Universidade do Distrito Federal, Anísio Teixeira delegou ao jornalista Costa Rego, editor do jornal Correio 
da Manhã, a incumbência de organizar um curso de jornalismo, que valorizasse a formação humanística profissional. Porém, as idéias de Anísio Teixeira e Costa Rego foram frustradas, quando o golpe do Estado Novo de Getúlio Vargas extinguiu a Universidade (LAURENTI, 2002, p. 146).

A idéia de Anísio Teixeira era de uma "universidade autônoma, não tutelada pelo Governo Federal” (MARQUES DE MELO, 2003a), com uma proposta diferente da sugerida inicialmente pela $A B I$. Não se tratava da criação de uma escola profissional,

mas de um curso universitário destinado a refletir sobre o fenômeno ascendente da cultura de massa, correlacionando duas atividades então imbricadas profissionalmente: 0 jornalismo e a publicidade. (MARQUES DE MELO, 2003a, p. 301)

Pretendendo, a universidade, criar "homens cultos", o projeto foi recebido pelas elites do Estado Novo com hostilidade. A idéia de que era um "núcleo de perigosos esquerdistas" difundiu-se na sociedade e junto ao Governo.

A experiência da Universidade do Distrito Federal, criada por um Decreto do prefeito Pedro Ernesto, durou apenas até 1939. Porém seu modelo inspirado no pragmatismo de Dewey, que Anísio Teixeira introduziu no Brasil, tornou-se paradigmático na criação do curso da Universidade do Brasil, em 1948. 


\subsection{O Jornalismo na Universidade: a Escola de Jornalismo Cásper Líbero}

Com a promulgação do Decreto-lei $n^{\circ} 5.480$, de 13 de maio de 1943, assinado pelo presidente da República, Getúlio Vargas, e pelo ministro da Educação e Saúde, Gustavo Capanema, que o curso de jornalismo finalmente começou a se concretizar. $\mathrm{O}$ artigo $3^{\circ}$ referia-se ao curso que seria ministrado pela Faculdade Nacional de Filosofia da Universidade do Brasil, com a cooperação da Associação Brasileira de Imprensa e dos sindicatos representativos das categorias de empregados e de empregadores das empresas jornalísticas. No caso de instituições não-federais, a organização do curso deveria estar de acordo com o Decreto-lei $n^{\circ} 421$, de 11 de maio de 1938, que regulava o funcionamento das instituições de ensino superior.

Mas quem saiu na frente foi a Fundação Cásper Líbero. Em 1947, atendendo ao testamento do jornalista, a Fundação, em convênio com a Faculdade de Filosofia, Ciências e Letras de São Bento da Pontifícia Universidade Católica de São Paulo, instituiu o curso, aprovado por meio do Decreto $\mathrm{n}^{\circ} 23.087$, de 19 de maio daquele ano.

A exemplo de Pulitzer, empresário do jornalismo norteamericano que efetuou uma doação à Columbia University para a formação de uma escola destinada à preparação de jornalistas, Cásper Líbero, proprietário do grupo " A Gazeta", foi o responsável pela instalação de uma entidade da mesma natureza, em São Paulo. (MARQUES DE MELO, 1974, p.19) 
Demonstrando seu pioneirismo, Cásper Líbero, um empresário progressista e preocupado com a formação de jornalistas, redigiu um testamento em março de 1943, antes mesmo do decreto governamental que instituiu o Curso de Jornalismo (de maio de 1943), legando seu patrimônio aos funcionários e à coletividade, transformando-o em uma Fundação. De acordo com o testamento de Cásper, além de sucedê-lo na propriedade de $A$ Gazeta, a Fundação teria a missão de fundar e manter uma escola de jornalismo, com "cursos de grandes proporções" destinados a formar quadros profissionais para a imprensa (JAYO, 2004).

Seu testamento dizia:

(...) Visto como tudo que possuo devo à Providência que não me há desamparado, e à GAZETA, jornal que é o reflexo e o orgulho de toda a minha existência de labores, sempre a serviço de São Paulo, do Brasil, da justiça e das grandes ideologias, quero e disponho que todos os meus bens remanescentes sejam reunidos e aplicados como patrimônio da fundação que ora crio e instituo (....). Será tríplice a sua finalidade ou objetivo, a saber: a) objetivo patriótico, de iniciativas e campanhas por São Paulo, pelo Brasil, pela justiça, pelos nobres ideais, pela cultura e grandeza de nossa Pátria, servindo-se para isso de $A$ GAZETA, do seu auditório, de seu rádio e dos recursos do patrimônio de que ora a doto; b) objetivo cultural, de criar e manter uma escola de jornalismo e ensinamentos de humanidades, particularmente português, prosa, estilo, literatura, eloqüência, história e filosofia, em cursos de grandes proporções, a começar pelo secundário e finalizar pelo superior; c) objetivo jornalístico, consistente em assegurar e desenvolver o nome, futuro, prosperidade, economia e prestígio de $A$ GAZETA, mantendo-a órgão de genuína opinião pública e interesse da pátria, aparelhada dos inventos e aperfeiçoamentos que o progresso for engendrando, fidelíssima da fundação (...). (LÍBERO apud HIME, 1997, p. 244-245)

Embora não tenha sido uma idéia original, em 1943, Cásper Líbero avalizou e deu "continuidade às ações da $A B I$, movendo-se, ao menos em 
parte, pelas mesmas motivações desta última, atribuíveis à necessidade de treinar profissionais preparados para lidar com a crescente modernização técnica da atividade jornalística" (JAYO, 2003).

Hime (1997) não se surpreende que fizesse parte de seu testamento a criação da primeira faculdade de jornalismo brasileira, porque mantinha-se ligado a todas as discussões presentes nos movimentos de classe de sua época, num momento em que imperava o debate sobre a necessidade de formação profissional no jornalismo. Além disso:

Como ele próprio tantas vezes afirmou, era um homem de jornal, que no jornal encontrava o estímulo necessário para as lutas a que se determinava. No jornal passava o dia. Chegava cedo, acompanhava de perto a produção, discutia as edições, recebia as pessoas. E mesmo quando expandia a sua atuação para além das páginas do vespertino, por meio de promoções e eventos, era ainda no jornal que se ancorava. (HIME, 1997, 235)

Hime lembra ainda que, em suas viagens aos Estados Unidos e Europa, Cásper teve contato com diferentes modelos de ensino do jornalismo. Embora não tenha especificado qual tipo de curso tivesse atraído mais sua atenção, havia indicações de que fosse um curso voltado para as Ciências Humanas.

Marques de Melo acredita que Cásper Líbero tivesse ainda motivações de cunho empresarial, principalmente por sua visão progressista.

Havia (...) demanda de pessoal habilitado para exercer profissionalmente um novo tipo de jornalismo, seguindo padrões que contrastavam com o desempenho da imprensa na época. 
Logo, a escola de jornalismo impunha-se como instrumento necessário para solucionar tal impasse treinando novas vocações, de acordo com a plataforma editorial, ética e política vigentes nas suas empresas. (MARQUES DE MELO, 1994, p.19)

Mas é preciso lembrar que Cásper tinha fortes convicções ideológico-religiosas. Em vida, cultivou o hábito de financiar pessoalmente os estudos de diversos de seus funcionários no Largo de São Francisco, entre outras formas de ajuda material. Por isso, não surpreende o fato de ter destinado uma parte de seu patrimônio à criação de uma escola de qualidade, com cursos gratuitos "de grandes proporções", destinados ao ensino do jornalismo.

Ele faleceu poucos meses depois de escrever seu testamento, em agosto de 1943. Mas, em 1947, "depois que o Ministério da Educação fixou as diretrizes pedagógicas para os cursos de jornalismo, começou a funcionar a instituição idealizada por Cásper Líbero" (MARQUES DE MELO, 1974, p. 21).

O curso da Escola Cásper Líbero da Faculdade de Filosofia da PUC-SP foi reconhecido em 1949. Nos primeiros anos, a orientação pedagógica do curso foi baseada no modelo norte-americano da Universidade do Missouri, de acordo com Rizzini (1953, p. 46), que afirmava que a Escola mantinha o jornal mensal, $A$ Imprensa, a cargo dos estudantes, "fiel ao princípio de que o aluno deve ver impresso aquilo que escreve". 
Mas Marques de Melo (1974) contesta essas afirmações. Segundo ele, um memorial dos alunos, em que entre os signatários estava o jornalista José Hamilton Ribeiro, encaminhado à Fundação, reclamava da falta de treinamento profissional prático. Marques também se utiliza da justificativa do programa da disciplina Técnica de Jornal, do ano de 1953, ministrada pelo jornalista Luís Silveira, para mostrar que o curso tinha a orientação voltada para a Faculdade de Jornalismo da Universidad Internacional "Pro-Deo" para as Ciências de Opinião de Roma.

O material que temos recebido desse notável instituto de ensino superior, de alto conceito universal, é que nos tem guiado na orientação do ensino da cadeira Técnica de Jornal. (SILVEIRA apud MARQUES DE MELO, 1974, p. 23)

O próprio Rizzini, em seminário promovido pelo Ciespal no Rio de Janeiro, em 1965, reconheceu que as escolas brasileiras tinham problemas com a parte prática do curso, satisfazendo apenas o lado cultural e não suas finalidades profissionais.

Mas o problema não estava unicamente na Escola Cásper Líbero. Veremos, mais adiante, que o curso da Universidade do Brasil sofria do mesmo problema. 


\subsection{0 curso na Universidade do Brasil}

Em 1948 começa a funcionar o curso de Jornalismo da Faculdade Nacional de Filosofia, Ciências e Letras da Universidade do Brasil. E aí começa a carreira de professor e catedrático de Danton Jobim, que trataremos mais à frente.

De acordo com Laurenti (2002), os primeiros cursos de Jornalismo no Brasil enfrentaram as dificuldades comuns e inerentes a um novo curso, que requer experiência para ganhar notabilidade e se posicionar no espaço acadêmico. Mas a dificuldade maior se dava em razão de sua vinculação com uma Faculdade de Filosofia, o que dificultava ainda mais sua estabilidade e luta pela legitimação do ensino.

Os entraves burocráticos que determinam subordinação à Faculdade de Filosofia, marginalizavam a sua condição e o conduziam a ser "simplesmente" um curso, sem o "status" de escola independente. (LAURENTI, 2002, p.151)

Sobre o assunto, Laurenti (2002) cita o parecer do relator Alceu Amoroso Lima, que afirmava que "o diploma do Curso de Jornalismo é um título cultural e não um privilégio profissional ou didático", e o de Jurandyr Lodi, que confirmava que fazendo parte de uma Faculdade de Filosofia não poderia se "constituir Escola isolada, com regulamentação isolada". 
O curso só ganharia autonomia em 6 de junho de 1958, com o Decreto $n^{\circ} 43.839$, que alterava o Decreto $n^{\circ} 26.493 / 49$, de 19 de março de 1949, autorizando que fosse ministrado em instituto autônomo.

De acordo com Cunha (1989, p.103-104), a distribuição de alunos nos cursos de Jornalismo nos dez anos iniciais foi a seguinte:

\begin{tabular}{|l|l|l|l|l|l|l|l|l|l|l|}
\hline Ano & 1948 & 1949 & 1950 & 1951 & 1952 & 1953 & 1954 & 1955 & 1956 & 1957 \\
\hline $\begin{array}{l}\mathrm{n}^{\circ} \\
\text { alun. }\end{array}$ & 366 & 497 & 710 & 524 & 483 & 362 & 390 & 336 & 461 & 426 \\
\hline
\end{tabular}

Uma curiosidade é que, dos 426 alunos matriculados no ano de 1957, 159 eram mulheres. O interessante é que essa proporção, superior a $37 \%$, não se repetia no ensino universitário no Brasil. Naquela época, de um total de 78.659 estudantes matriculados, apenas $26 \%$ eram do sexo feminino. Só a título de ilustração, em 1964 o número de alunos chegava a 1.265 e, em 1986, quando o curso já havia se transformado em curso de Comunicação Social, 10.637 estavam matriculados apenas na habilitação em Jornalismo.

Um dos problemas é que o curso foi recebido com ceticismo, principalmente por parte dos profissionais mais antigos. Jobim lembra que o próprio autor da aula inaugural insistiu que o importante do curso era a parte teórica relacionada com as disciplinas de cultura geral em detrimento da prática. Segundo ele, o autor "insistiu no preconceito de que 'jornalismo 
não se aprende na escola, mas na banca de redação'”, refletindo a imagem apregoada na época e, muitas vezes, repetida até os dias de hoje.

Jobim comemorou, em 1958, que essa "atmosfera de hostil ceticismo que se formara em torno do curso nos círculos jornalísticos" havia desaparecido, embora se saiba que ela permanece até hoje, principalmente entre os jornalistas remanescentes das décadas de 50 a 70, período em que o diploma não era obrigatório.

Mas o clima de hostilidade não impediu uma grande procura inicial pelos cursos. Jobim (2003, p.212) aponta os seguintes números de alunos ingressantes no curso da Universidade do Brasil nos seus dez primeiros anos iniciais:

\begin{tabular}{|l|l|l|l|l|l|l|l|l|l|l|}
\hline Ano & 1948 & 1949 & 1950 & 1951 & 1952 & 1953 & 1954 & 1955 & 1956 & 1957 \\
\hline $\begin{array}{l}\mathbf{n}^{\circ} \\
\text { alun. }\end{array}$ & 336 & 151 & 286 & 106 & 47 & 44 & 60 & 51 & 59 & 40 \\
\hline
\end{tabular}

Nos primeiros anos, havia uma grande diferença entre o número de alunos ingressantes pelo concurso vestibular e o número de alunos matriculados. Tal diferença devia-se, principalmente, à facilidade inicial de ingresso dos candidatos que já exerciam a profissão de jornalistas. Deles não era exigida nem mesmo a conclusão do curso secundário, muito menos a aprovação no vestibular. Com o desaparecimento dessas 
facilidades e com o estabelecimento de limites para o número de matrículas (apenas 40 vagas), as turmas diminuíram consideravelmente.

O curso sofreu diversas modificações no seu currículo inicial, como se descreve mais à frente. Mesmo assim, segundo Marques de Melo (1974, p. 31), "o ensino ali ministrado não conseguiu atingir os objetivos originais pretendidos pelos dirigentes jornalísticos que lutaram pela sua criação".

Jobim (2003, p. 219), no entanto, reconhecia que existiam problemas de desajustamento entre os meios de que dispunham e as necessidades de um ensino eficiente para a formação de bons profissionais. Mas acreditava que, "tanto pela sua qualidade, como pela experiência acumulada durante dez anos", o pessoal docente enfrentava os problemas com sucesso.

Sobre as mudanças na grade curricular do curso de Jornalismo, Jobim, em 1958, em exposição no Seminário sobre Formação de Jornalismo, realizado em Quito, no Equador, comentou:

O número de reformas sofridas pelos cursos em dez anos de vida mostra o interesse que põem as autoridades do ensino e a congregação da faculdade em dar-lhe cada vez maior eficiência. Nos debates em torno dessas reformas, tem-se mantido com segurança o critério de que o nível de instrução ministrado deve ser o universitário ou de ensino superior e não o de um curso para a simples formação de práticos em jornalismo. Um jornalista - esta é a opinião generalizada - tanto precisa de conhecimentos básicos na sua profissão como de uma cultura geral de nível universitário. Elevar o padrão não apenas profissional, no sentido estrito, mas ainda cultural e ético do ofício, esta é a missão das boas escolas de jornalismo, qual têm 
participado inclusive os professores das cadeiras técnicas. (JOBIM, 2003, p. 216-217)

Embora defendesse um ensino amplo em países "onde as disciplinas do curso secundário são, em geral, deficientemente ensinadas", Jobim queixava-se da falta do trabalho prático que deveria ser realizado pelos alunos. Ele acreditava que o contato direto com a profissão, através da redação de textos - notícias, reportagens e editorias - era pouco utilizado pela universidade e pela imprensa, que relutava em abrir espaço para os estudantes. Da mesma forma, o estágio previsto em redações era irregularmente praticado, principalmente pelo fato de os bons repórteres e redatores não terem tempo disponível para acompanhar os iniciantes, deixando-os nas mãos de profissionais menos capacitados.

Para resolver esse problema, Jobim defendia a necessidade de laboratórios gráficos e da criação de jornais-laboratórios, que terminaram por ser implantados tempos depois. Para ele, isso possibilitaria aos alunos um treinamento mais completo de paginação, que até aquele momento ficava restrito às técnicas de diagramação e espelhagem. Porém, Jobim acreditava que a importância maior na criação de veículos laboratoriais estava na mudança de atitude do aluno, que passaria a escrever "matéria destinada a ser lida pelo público e não somente pelo professor" (JOBIM, 2003, p.215).

Outro problema era a falta de material didático. O professor reconhecia que a literatura em língua portuguesa era praticamente 
inexistente. Os professores das disciplinas técnicas utilizavam material que era levado das redações para as salas de aula, como papel padronizado para originais, papel centimetrado para espelhos, réguas de medidas gráficas, fotografias e negativos, catálogos de tipos, entre outros.

Mas o número de horas dispensadas às disciplinas técnicas era significativo e representava cerca de um terço das disciplinas teóricas, embora estas fossem em um número muito maior. Mesmo com as práticas se restringindo apenas a técnica de jornal, técnica de periódico, administração de jornal, publicidade e rádiojornalismo. Isto no que se refere ao ano de 1958.

Porém, Jobim também confirmava que, do mesmo modo que os alunos da Escola Cásper Líbero de São Paulo, os alunos da Universidade do Brasil também se queixavam de que o ensino era "excessivamente acadêmico", o que, para ele, se devia em parte "à falsa noção de que o curso de jornalismo deve ser meramente profissional, reduzindo ao mínimo o tempo dispensado às matérias não-técnicas" (JOBIM, 2003, p. 216). Ele acrescentava que essas disciplinas "de ilustração" visavam dar a base cultural necessária a qualquer jornalista, além de terem programas próprios adaptados às finalidades do curso.

Jobim acreditava que os resultados obtidos depois dos primeiros dez anos de cursos, "ao menos do ponto de vista do nível técnicoprofissional do jornalismo", eram positivos. Principalmente porque, antes da instituição do ensino superior de jornalismo, não se notavam esforços para "melhorar o padrão do estilo das notícias e de sua titulação". Embora 
confessasse a falta de pesquisa na área, ele acreditava que a melhora na imprensa se devia ao curso.

O curso só sofreu uma mudança radical depois que a reforma universitária, instituída pelo Decreto $n^{\circ}$ 60.455-A, de 13 de março de 1967, já na então Universidade Federal do Rio de Janeiro (UFRJ) — novo nome da Universidade do Brasil —, criou a Escola de Comunicação (ECO), dotada de autonomia didática e administrativa.

\subsection{Os primeiros currículos do Curso de Jornalismo}

O currículo inicial do curso de Jornalismo, por determinação do Decreto $\mathrm{n}^{\circ}$ 22.245, de 6 de dezembro de 1946, previa seções que se dividiam em Formação, Aperfeiçoamento e Extensão Cultural, com as seguintes disciplinas:

\begin{tabular}{|c|c|c|}
\hline $1^{\circ}$. Ano & $2^{\circ}$. Ano & $3^{\circ}$. Ano \\
\hline Português e Literatura & Português e Literatura & Português e Literatura \\
\hline Francês ou Inglês & Sociologia & Psicologia Social \\
\hline Geografia Humana & Política & Economia Política \\
\hline História da Civilização & História do Brasil & Noções de Direito \\
\hline $\begin{array}{l}\text { Ética e Legislação de } \\
\text { Imprensa }\end{array}$ & História da Imprensa & $\begin{array}{l}\text { Organização e } \\
\text { Administração de } \\
\text { Jornal }\end{array}$ \\
\hline Técnica de Jornalismo & Técnica de Jornalismo & Técnica de Jornalismo \\
\hline
\end{tabular}


Além disso, o curso, distribuído em três anos, previa ainda mais duas disciplinas optativas por ano, escolhidas entre: Introdução à Filosofia, História Contemporânea, História da América, História das Artes, História da Música, Direito Constitucional, Direito Administrativo, Educação Comparada e Estatística (LAURENTI, 2002).

Existia o estágio obrigatório, amparado na disciplina Técnica de Jornalismo, e a seção de Aperfeiçoamento, que consistia em conferência e trabalhos práticos para os profissionais de imprensa.

Em 1948, o Decreto $\mathrm{n}^{\circ} 24.719$, de 29 de março, mudava a estrutura curricular do curso. O novo currículo distribuía a grade da seguinte forma:

\begin{tabular}{|c|c|c|}
\hline 10. Ano & $2^{\circ}$. Ano & $3^{\circ}$. Ano \\
\hline Português e Literatura & Português e Literatura & Português e Literatura \\
\hline Francês & Francês & Psicologia Social \\
\hline Inglês & Inglês & $\begin{array}{l}\text { Noções de Direito e } \\
\text { Economia }\end{array}$ \\
\hline Geografia Humana & Sociologia e Política & $\begin{array}{l}\text { Publicidade, } \\
\text { Organização e } \\
\text { Administração de } \\
\text { Jornal }\end{array}$ \\
\hline História da Civilização & História do Brasil & Técnica de Jornalismo \\
\hline $\begin{array}{l}\text { Ética, História e } \\
\text { Legislação de } \\
\text { Imprensa }\end{array}$ & Técnica de Jornalismo & Radiodifusão \\
\hline Técnica de Jornalismo & & \\
\hline
\end{tabular}

É importante ressaltar que, a partir desse momento, o meio eletrônico - no caso, o rádio - foi incluído no currículo, mostrando uma preocupação com a atualização das mídias. 
Em 1949, o currículo foi novamente alterado pelo Decreto $n^{\circ}$ 26.493, de 19 de março. O novo currículo tornava as disciplinas de Inglês

e Francês facultativas e dividia a seção de Aperfeiçoamento em duas: Aperfeiçoamento em Técnica e em Cultura Geral (LAURENTI, 2002). Com a divisão, as disciplinas ficaram separadas da seguinte forma:

\section{Aperfeiçoamento em Técnica}

\begin{tabular}{|l|l|}
\hline \multicolumn{1}{|c|}{$\mathbf{1}^{\mathbf{0}}$. Ano } & \multicolumn{1}{c|}{$\mathbf{2}^{\mathbf{0}}$. Ano } \\
\hline $\begin{array}{l}\text { Ética, História e Legislação da } \\
\text { Imprensa }\end{array}$ & Técnica de jornalismo \\
\hline Técnica de Jornalismo & Prática de Imprensa \\
\hline Prática de Imprensa & $\begin{array}{l}\text { Publicidade, Organização e } \\
\text { Administração de Jornal }\end{array}$ \\
\hline Noções de Direito e Economia & Radiodifusão \\
\hline
\end{tabular}

\section{Aperfeiçoamento em Cultura Geral}

\begin{tabular}{|l|l|}
\hline \multicolumn{1}{|c|}{$\mathbf{1}^{\mathbf{0}}$. Ano } & \multicolumn{1}{c|}{$\mathbf{2}^{\mathbf{0}}$. Ano } \\
\hline Português e Literatura & Sociologia e Política \\
\hline História da Civilização & Noções de Direito e Economia \\
\hline Literatura Contemporânea & História do Brasil \\
\hline Geografia Humana & Administração Pública \\
\hline Estatística & \\
\hline
\end{tabular}

Em 1950, novamente ocorre uma reestruturação no curso. Dessa vez foi em razão da reestruturação do curso de Jornalismo da Faculdade de Filosofia da Universidade do Brasil. Por analogia, os demais cursos 
foram reestruturados, de acordo com o Decreto $n^{\circ} 28.923 / 50$. A diferença é que foi criada uma parte básica nos dois primeiros anos de curso e uma parte na qual o aluno poderia optar pela grade que tivesse mais interesse de cursar no terceiro ano (LAURENTI, 2002). O curso foi estruturado da seguinte forma:

\section{Primeira Parte (Básica)}

\begin{tabular}{|l|l|}
\hline \multicolumn{1}{|c|}{$\mathbf{1}^{\mathbf{0}}$. Ano } & \multicolumn{1}{c|}{$\mathbf{2}^{\mathbf{0}}$. Ano } \\
\hline Técnica de Jornal & Técnica de jornal \\
\hline $\begin{array}{l}\text { Ética, História e Legislação da } \\
\text { Imprensa }\end{array}$ & Publicidade \\
\hline Administração de Jornal & $\begin{array}{l}\text { Língua Portuguesa e Literatura de } \\
\text { Língua Portuguesa }\end{array}$ \\
\hline História da Civilização & História do Brasil \\
\hline $\begin{array}{l}\text { Língua Portuguesa e Literatura de } \\
\text { Língua Portuguesa }\end{array}$ & História Contemporânea \\
\hline Geografia Humana & Geografia do Brasil \\
\hline
\end{tabular}

Segunda Parte (Opcionais)

\begin{tabular}{|l|l|l|}
\hline \multicolumn{1}{|c|}{$\begin{array}{c}\mathbf{3}^{\mathbf{0}} \text {. Ano } \\
\text { (Modalidade A) }\end{array}$} & \multicolumn{1}{c|}{$\begin{array}{c}\mathbf{3}^{\mathbf{0}} \text {. Ano } \\
\text { (Modalidade B) }\end{array}$} & \multicolumn{1}{c|}{$\begin{array}{c}\mathbf{3}^{\mathbf{0}} \text {. Ano } \\
\text { (Modalidade C) }\end{array}$} \\
\hline $\begin{array}{l}\text { Radiojornalismo ou } \\
\text { Técnica de Periódico }\end{array}$ & $\begin{array}{l}\text { Radiojornalismo ou } \\
\text { Técnica de Periódico }\end{array}$ & Radiojornalismo \\
\hline Sociologia & História das Artes & Introdução à Educação \\
\hline Economia & $\begin{array}{l}\text { Literatura de Língua } \\
\text { Portuguesa }\end{array}$ & Psicologia Social \\
\hline $\begin{array}{l}\text { Política e } \\
\text { Administração Pública }\end{array}$ & $\begin{array}{l}\text { Literatura } \\
\text { Contemporânea }\end{array}$ & Criminologia \\
\hline Técnica de Jornal & Técnica de Jornal & Técnica de Jornal \\
\hline
\end{tabular}


As atividades práticas em redação, oficinas e estúdios ficavam relacionadas com as disciplinas Técnica de Jornal, Técnica de Periódico e Radiojornalismo. O estágio, segundo o decreto, deixava de ser obrigatório e passava a ser oferecido "sempre que possível". O decreto também assegurava aos formandos, a partir de 1950, o diploma de bacharel em Jornalismo (LAURENTI, 2002).

Naquele ano, um novo currículo havia sido aprovado pela Congregação da Faculdade Nacional de Filosofia. A principal diferença estava na mudança de três para quatro anos de curso. Quanto às disciplinas, a base era praticamente a mesma:

\begin{tabular}{|c|c|c|c|}
\hline $1^{\circ}$. Ano & $2^{\circ}$. Ano & $3^{\circ}$. Ano & $4^{\circ}$. Ano \\
\hline $\begin{array}{l}\text { Ética, História e } \\
\text { Legislação de } \\
\text { Imprensa }\end{array}$ & $\begin{array}{l}\text { Técnica de } \\
\text { Jornal }\end{array}$ & Técnica de Jornal & $\begin{array}{l}\text { Técnica de } \\
\text { Jornal }\end{array}$ \\
\hline $\begin{array}{l}\text { Administração de } \\
\text { Jornal }\end{array}$ & Publicidade & Radiojornalismo & $\begin{array}{l}\text { Técnica de } \\
\text { Periódico }\end{array}$ \\
\hline $\begin{array}{l}\text { Português e } \\
\text { Literatura da } \\
\text { Língua } \\
\text { Portuguesa }\end{array}$ & $\begin{array}{l}\text { Português e } \\
\text { Literatura da } \\
\text { Língua } \\
\text { Portuguesa }\end{array}$ & $\begin{array}{l}\text { Português e } \\
\text { Literatura da } \\
\text { Língua } \\
\text { Portuguesa }\end{array}$ & $\begin{array}{l}\text { Literatura } \\
\text { Contemporânea }\end{array}$ \\
\hline $\begin{array}{l}\text { Geografia } \\
\text { Humana }\end{array}$ & $\begin{array}{l}\text { Geografia do } \\
\text { Brasil }\end{array}$ & Sociologia & $\begin{array}{l}\text { História das } \\
\text { Artes }\end{array}$ \\
\hline $\begin{array}{l}\text { História da } \\
\text { Civilização }\end{array}$ & $\begin{array}{l}\text { História } \\
\text { Contemporânea }\end{array}$ & $\begin{array}{l}\text { Introdução à } \\
\text { Educação }\end{array}$ & Economia \\
\hline História do Brasil & Psicologia Social & $\begin{array}{l}\text { Política e } \\
\text { Administração } \\
\text { Pública }\end{array}$ & Criminologia \\
\hline
\end{tabular}


Em 1957, dez anos depois de criado, já existiam nove cursos no Brasil (JOBIM, 2003, p.109), a saber:

Rio de Janeiro: 2 (dois) com 166 alunos

São Paulo: 2 (dois) com 77 alunos

Rio Grande do Sul: 2 (dois) com 131 alunos

Bahia: 1 (um)

Minas Gerais: 1 (um)

Paraná: 1 (um) com 52 alunos

Dessas, três eram instituições públicas e seis eram particulares. Entre as particulares, destacavam-se as instituições católicas de ensino, com quatro cursos de Jornalismo, que absorviam pouco mais da metade do total de alunos matriculados naquele ano (218 alunos).

A situação atual das escolas é muito diferente. Segundo dados do Censo de Ensino Superior de 2003, o número de cursos de Jornalismo existentes é de 443. Apenas entre os anos de 2000 e 2003, o número de cursos teve um aumento de $70 \%$. Desses, 74 são de escolas públicas e 369 de escolas privadas. O levantamento, no entanto, segundo a Federação Nacional de Jornalistas (FENAJ), inclui como "Jornalismo" todos os cursos de graduação em Cinema e Vídeo, Jornalismo, Noticiário e Reportagem, Radialismo, Rádio e Telejornalismo, Comunicação Social, Produção Editorial e Publicação. 
A FENAJ explica que o curso que alavancou todo o crescimento detectado pelo Instituto Nacional de Estudos e Pesquisas Educacionais Anísio Teixeira (INEP) foi o de Comunicação Social, que passou de 220 em 2000 para 423 em 2003, um incremento de 92,3\%. "Os dados precisam, no entanto, ser tomados com precaução, pois pode ter havido confusão na hora de classificar os cursos. É possível que nas listas de Comunicação Social tenham sido contabilizadas outras habilitações que não as de Jornalismo" (FENAJ, 2005). Isso porque no site do INEP consta que são 312 os cursos de Jornalismo, ou de Comunicação Social com habilitação em Jornalismo no país. 


\section{Biografia - Uma vida dedicada à imprensa}

Danton Pinheiro Jobim nasceu em Avaré, Estado de São Paulo, no dia 8 de março de 1906. Era filho de Francisco Antenor Jobim, juiz de direito, e de Joaquina Pinheiro Jobim. Seu irmão, José Jobim, foi jornalista e diplomata, e chegou à Embaixada do Brasil no Paraguai entre 1958 e 1959. Seu avô materno foi José Gomes Pinheiro Machado, senador pelo Rio Grande do Sul entre 1891 e 1915, figura exponencial na política brasileira no início do século passado. Foi casado com Nadir Pena Magalhães Fausto, com quem teve dois filhos, Roberto Luís Fausto Jobim e Renato Sérgio Fausto Jobim.

Cursou o primário no grupo escolar de Itápolis e o secundário, já morando no Rio de Janeiro, então Capital Federal, no Instituto Lafayette. Completou seus estudos preparatórios no Colégio de Juruena de Matos, onde foi aluno de Austregésilo de Ataíde, que viria a ser presidente da Academia Brasileira de Letras, a partir de 1959. Cursou a Faculdade Nacional de Direito do Rio de Janeiro (ABREU et al, 2001).

Iniciou a carreira jornalística no Rio em 1923, na redação de 0 Trabalho, jornal vinculado ao então jovem Partido Comunista Brasileiro. Logo, Jobim filiou-se ao PCB e foi, durante alguns anos, um de seus representantes no meio jornalístico.

Após poucos meses, com o fechamento de O Trabalho, transferiuse para A Noite, jornal fundado em 1911 por Irineu Marinho. Segundo ele, 
era um "aprendizado jornalístico, quer na redação, quer nas oficinas" (JOBIM apud ABREU et al, 2001). Foi lá que, além do jornalismo, aprendeu o planejamento gráfico, que utilizaria mais tarde no $A$ Manhã. Com sua formação em Direito, ficou responsável pela cobertura do Foro, mas também escrevia crônicas de livros e, algumas vezes, notícias para uma seção de variedades chamada "Ecos".

Nesse período também escreveu para outros jornais, destacando aí um artigo sobre o pintor Cândido Portinari no jornal Correio da Manhã e outro sobre acidentes com gases poluentes dos motores de automóveis para o jornal O Globo. Esta, segundo ele, foi sua primeira reportagem colocada na primeira página pelo secretário de redação Euricles de Matos, que tinha como título "O inimigo invisível das grandes cidades".

Por mera curiosidade, esclareço que se tratava, já naquele
tempo, de um brado de alerta contra a poluição da atmosfera: o
relato de diversos acidentes ocasionados pelos gases
desprendidos dos motores de automóveis. (JOBIM In: O
GLOBO, 1973)

Convidado para trabalhar no jornal $A$ Manhã, fundado em 1925 por Mário Rodrigues, lá introduziu métodos novos de paginação, considerados avançados para padrões da época.

No ano seguinte, 1926, ingressa na Associação Brasileira de Imprensa - $\mathrm{ABI}$, tornando-se logo um dos conselheiros mais destacados. Nesse período, continuava com sua militância política junto ao PCB, chegando mesmo a realizar uma conferência na sede da União dos 
Trabalhadores Gráficos do Rio de Janeiro, como parte de uma programação patrocinada pelo Bloco Operário do PCB.

Em 1929, foi com Mário Rodrigues para o jornal $A$ Crítica. Sua atuação política continuava, tendo, em julho de 1929, representado o PCB, junto com Leôncio Basbaum e Mário Grazini, na I Conferência LatinoAmericana dos Partidos Comunistas, realizada em Buenos Aires. Logo após sua volta, foi contratado por Assis Chateaubriand para secretariar o recém-criado Diário de São Paulo, matutino vinculado aos Diários Associados, e politicamente comprometido com as idéias da coligação oposicionista Aliança Liberal.

Mas sua passagem pela capital paulista foi rápida. Um ano depois Jobim retornava ao Rio de Janeiro e à imprensa carioca. No início da década de 30 , passou por jornais com claros vínculos à esquerda, como $A$ Batalha, criado em 1929 por Pedro Mota Lima e depois dirigido por Júlio Barata, e o Diário de Notícias, matutino fundado em 12 de junho de 1930, por Orlando Ribeiro Dantas, com a proposta de lutar contra a "estrutura oligárquica” da República Velha (ABREU et al, 2001). Com posições fortemente definidas, recebeu o título de "O jornal da revolução" e chegou a vender 168 mil exemplares no dia 24 de outubro, dia da deposição de Washington Luís, com a manchete: "O Brasil despertou de um grande pesadelo — o Brasil está livre da politicalha de ódios e vinganças". Porém o jornal, ao mesmo tempo, mostrava reserva à junta revolucionária que assumiu o Governo e demonstrava simpatia aos que chamava de "verdadeiros arquitetos da revolução": os tenentes. 
E foi também para um jornal simpático ao movimento tenentista que Jobim se transferiu depois: $A$ Esquerda, dirigido, na época, por Carlos Sussekind de Mendonça, que havia sido redator em A Batalha. Os dois jornais tiveram mais pontos em comum: recebiam subvenções do bicheiro João Pallut, a quem interessava encobrir sua atividade no jogo do bicho. Pallut chegou a ser proprietário de A Batalha quando Pedro Mota Lima se afastou. Embora não fosse considerado um porta-voz do PCB, A Esquerda apresentou-se como um jornal nacionalista e preocupado com a defesa do operariado, defendia Luís Carlos Prestes e o que chamava de uma "ditadura construtora", que tivesse à frente um líder sem compromissos com os partidos existentes e com as oligarquias.

Em meados de 1931, Jobim passou a trabalhar na Agência Meridional de Notícias, vinculada aos Diários Associados. Mas logo no ano seguinte, 1932, transferiu-se para o Diário Carioca, jornal fundado em 1928 por José Eduardo de Macedo Soares e dirigido por Horácio de Carvalho Júnior. Entrou como redator político, foi promovido a secretário de redação e, depois, a diretor de redação. Lá trabalhou 33 anos, até o jornal ser extinto. Após se desligar do PCB, em 1934, tornou-se responsável também pelos editoriais políticos da primeira página, tarefa que dividia com Macedo Soares, "resistindo, conforme afirmaria mais tarde, a todas as tentações de posicionar-se 'à direita ou à esquerda'" (ABREU et al, 2001, p. 2842).

Ao Diário Carioca dedicaremos um capítulo especial, já que a maior parte da carreira de Jobim como jornalista foi exercida naquele veículo. Lá 
também se formou uma nova geração de jornalistas e um novo jornalismo no país. E onde Jobim pôde pôr em prática suas novas idéias a respeito do ensino do jornalismo.

Embora alegando resistir às tentações, Jobim foi um homem político que explicitava suas posições, assim como o jornal que dirigiu durante tanto tempo. Apoiou a implantação do Estado Novo, em 1937. Chegou a ser nomeado, naquela época, diretor do Departamento de Propaganda e Turismo do Estado do Rio de Janeiro, governado pelo interventor federal Ernani Amaral Peixoto. Mas, com o controle da imprensa que, por meio do Departamento de Imprensa e Propaganda, chegou a censurar seus editoriais, mudou de posição e passou a combater a ditadura Vargas.

Nesse período, passou a trabalhar na campanha de redemocratização do país, principalmente no Clube dos Diretores de Jornais, onde atuava ao lado de Macedo Soares, Elmano Cardim (diretor do Jornal do Comércio, que substituiu Félix Pacheco), Oséias Mota (um dos fundadores dos jornais $A$ Noite e $A$ Rua e diretor-proprietário do jornal A Vanguarda), Mário Magalhães, Georgino Avelino (ex-deputado federal pelo Rio Grande do Norte e editorialista de diversos jornais do Rio), João Mangabeira (ex-jornalista e deputado federal pela Bahia), Francisco de San Tiago Dantas, entre outros. O grupo protestava sem êxito junto a Filinto Muller, então chefe de polícia do Distrito Federal, passando então, em conjunto, a queixar-se ao presidente Getúlio Vargas sobre as ameaças que vinham sofrendo. 
Entre os anos de 1936 e 1937, de acordo com Amaral Peixoto, Jobim fez parte do movimento que lutava pela criação do Sindicato dos Jornalistas Profissionais do Município do Rio de Janeiro.

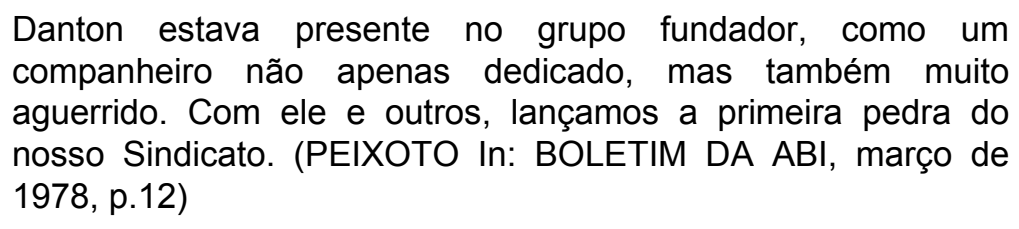
companheiro não apenas dedicado, mas também muito aguerrido. Com ele e outros, lançamos a primeira pedra do nosso Sindicato. (PEIXOTO In: BOLETIM DA ABI, março de 1978, p.12)

Jobim também foi comentarista do programa de rádio $A$ Marcha da Guerra, patrocinado pelo governo norte-americano e transmitido em cadeia nacional, a partir de 1939, com a eclosão da Segunda Guerra Mundial. Nesse período, um de seus companheiros de trabalho, responsável pela análise sobre a evolução da situação militar na Europa, foi o tenente-coronel Humberto Castelo Branco, que se tornou, mais tarde, presidente da República durante o regime militar. Jobim conheceu Castelo Branco anos antes, durante as férias com a família, e acabou por indicá-lo para o cargo de comentarista. Mesmo discordando politicamente dele alguns anos mais tarde e criticando-o no cargo de presidente por meio de seus artigos, mostrou-se sempre respeitoso com o amigo.

Após a reorganização partidária ocorrida em 1945, Jobim filiou-se ao Partido Republicano, liderado pelo ex-presidente Artur Bernardes, que apoiava a candidatura do brigadeiro Eduardo Gomes à Presidência da República.

Em 1948, Jobim foi convidado para assumir a cátedra de Jornalismo do recém-criado curso na Faculdade Nacional de Filosofia da Universidade 
do Brasil, que mais tarde se transformaria na Escola de Comunicação da Universidade Federal do Rio de Janeiro (UFRJ). Na carreira docente da UFRJ, Jobim seguiu até 1976 como professor titular, e ocupando a vicediretoria da Escola até 1970, quando foi para o Senado Federal.

Como profissional e professor de Jornalismo, Jobim teve reconhecimento internacional. Primeiro, em 1952, ao receber o prêmio "Maria Moors Cabot", conferido pela Universidade de Colúmbia, nos Estados Unidos, aos jornalistas latino-americanos que mais se destacassem na luta pela liberdade de imprensa. Depois, em 1953, ao ser convidado para dirigir um seminário sobre jornalismo comparado na Universidade do Texas. Em 1957, ao ser convidado para uma série de conferências na Sorbonne, no Instituto de Altos Estudos sobre a América Latina e no Instituto de Estudos Políticos em Paris, França. E, finalmente, em 1958, quando foi convidado para lecionar Didática de Jornalismo no Centro de Estudos Superiores de Jornalismo da América Latina (Ciespal), em Quito, no Equador. O Ciespal é uma entidade vinculada à Organização das Nações Unidas para a Educação, a Ciência e a Cultura (Unesco).

No ano de 1963, Jobim presidiu o Movimento Pró-Beatificação e Canonização do Padre José de Anchieta, tendo sido recebido pelo Papa Paulo VI para a entrega de uma carta assinada por altas autoridades brasileiras. Sua ligação com a Igreja tornou-se tão forte a partir de então que, em um almoço no Clube Ginástico Português, no Rio de Janeiro, em homenagem aos seus 50 anos de imprensa, no dia 15 de março de 1973, Jobim recebeu uma mensagem do Papa Paulo VI concedendo a ele a 
benção apostólica. No mesmo evento, Jobim recebeu ainda mensagem do Cardeal Dom Agnelo Rossi, prefeito da Sagrada Congregação para a Evangelização dos Povos, do Vaticano, que ressaltava "seu valor extraordinário de homem identificado com as tradições mais gloriosas do Brasil”.

O bispo metodista Benjamim de Moraes Filho descobriu essa religiosidade de Jobim quase que por acaso, quando convidou-o para uma cerimônia em uma igreja evangélica no subúrbio de Cascadura, no Rio de Janeiro. Na ocasião, Jobim falou cerca de 40 minutos, com conhecimento e segurança, sobre o versículo "Conhecereis a verdade e a verdade vos libertará".

\begin{abstract}
Essa versatilidade de Danton Jobim me provocou agradável surpresa, não apenas pelo domínio que ele revelou do tema, mas pela sinceridade que recobria suas palavras. (...) $\mathrm{Na}$ verdade, esse tema se adequava à perfeição do temperamento e à formação de Danton. Ao proclamar num recinto sagrado que a verdade é um meio de libertação, Danton demonstra coerência com sua atuação à frente da $\mathrm{ABI}$, onde desenvolveu ação paciente, porém vigorosa contra a censura e contra quaisquer restrições à liberdade de imprensa. $E$ isso que impunha à nossa admiração a sua extraordinária figura: não havia conflito nem contradição entre o pensamento que ele expunha de forma límpida numa oração de improviso, como aquela feita naquele encontro que conservo envolvido em saudade, e a sua prédica diária em favor da liberdade de imprensa. (MORAES FILHO In: BOLETIM DA ABI, março de 1978, p. 12)
\end{abstract}

Sem dúvida, essa mudança de postura chamou a atenção de seus colegas. Fernando Segismundo ${ }^{4}$ conta que chegou a dizer para o companheiro de gestão na $\mathrm{ABI}$ : "você está exagerando nesse negócio de

\footnotetext{
${ }^{4}$ Em entrevista à autora em 07/09/05.
} 
religião". Explica que a observação se dava em razão de tê-lo conhecido num período em que era "marxista e comunista ativo", com forte representatividade junto ao PCB. "Eu não quero ser irreverente, mas ele mudou e eu vi o Danton comungar. Eu tomei um susto", reforça Segismundo, defendendo porém a posição de Jobim: "Eu acho fabulosas essas mudanças, como o ser humano é flexível. Eu acho fabuloso ele ter tido essa coragem de se manifestar".

Nesse mesmo ano, Jobim tornou-se diretor proprietário do Diário Carioca. Após o movimento militar de 31 de maio de 1964, responsável pela queda do presidente João Goulart, Jobim passou suas ações para Horácio de Carvalho Júnior.

Em janeiro de 1965, assumiu o cargo de diretor-presidente da Última Hora, substituindo Samuel Wainer, cujos direitos políticos tinham sido cassados pelo regime militar. Nessa fase, a cobertura internacional passou a contar com o direito de reprodução dos artigos e reportagens das maiores publicações européias, como Le Monde, L'Express, L'Evènement e New Statesman. Última Hora lançava assim a seção "Jornal do Mundo".

Com a extinção dos partidos políticos pelo Ato Institucional $n^{\circ} 2$ e a conseqüente implantação do bipartidarismo, Jobim filiou-se ao Movimento Democrático Brasileiro (MDB), o partido da oposição. Em 1966, concorreu ao Senado pelo Estado da Guanabara, mas foi derrotado por seu colega de partido, Mário Martins, que acabou cassado pelo Ato Institucional $n^{\circ} 5$, em 1968. Com o apoio do então governador da Guanabara, Antonio de Pádua Chagas Freitas, Jobim foi eleito pelo MDB para completar o 
mandato de Martins. Junto com ele, foram para o Senado mais dois políticos cariocas ilustres do MDB: Nélson Carneiro e Benjamin Farah.

Durante esse período, entre 1966 e 1972, Jobim foi eleito e reeleito três vezes para a Presidência da Academia Brasileira de Imprensa (ABI). Sua gestão chegou a ser polêmica em determinados momentos, como no caso do convite ao então presidente da República, marechal Artur da Costa e Silva, para um evento na $A B I$ em comemoração aos 60 anos da entidade, em abril de 1968. No entanto, Jobim aproveitou a presença de Costa e Silva para proferir um discurso inflamado sobre liberdade de imprensa, justamente em um dos momentos mais duros da ditadura militar. Ao mesmo tempo, conseguiu a revogação de um ato de exceção que impedia os jornalistas Antonio Calado e Léo Guanabara de exercerem a profissão. Atuou também, nessa época, como representante da $A B I$ junto ao Conselho de Defesa dos Direitos da Pessoa Humana, em Brasília.

A atuação era a mesma no Senado, com discursos fortes na defesa da liberdade de imprensa e das prerrogativas dos jornalistas na cobertura dos fatos que redundassem em interesse público. Para ocupar a cadeira no Senado, deixou o cargo de vice-diretor da Escola de Comunicação da UFRJ, mas continuou lecionando. Ocupou, de 1971 a 1975, a viceliderança do MDB no Senado e participou de várias comissões, como a de Redação (Legislativa), de Finanças, de Relações Exteriores, de Transportes, de Comunicações e de Obras Públicas.

Reeleito para o Senado em 1974 com mais de 1,2 milhão de votos, Jobim alinhou-se com a corrente liderada por Chagas Freitas, que 
disputou a primazia dentro do partido com o grupo liderado pelo senador fluminense Ernani Amaral Peixoto. E venceu. Isto porque, em 1965, ocorreu a fusão dos Estados da Guanabara e do Rio de Janeiro.

Em janeiro de 1978, Jobim foi eleito mais uma vez para a Presidência da $A B I$, dessa vez em substituição a Prudente de Morais Neto, que havia falecido em dezembro de 1977. Ficou pouco tempo no cargo.

Morreu de embolia pulmonar no Rio de Janeiro, em 26 de fevereiro de 1978, em pleno exercício do mandato parlamentar como senador do Estado do Rio de Janeiro e da Presidência da ABI. Sua morte, cercada de mistérios, está sendo investigada atualmente. O professor da Escola de Comunicação da Universidade Federal do Rio de Janeiro, José Amaral Argolo, apresentou recentemente, no $3^{\circ}$ Encontro da Rede Alfredo de Carvalho, artigo em que questiona as circunstâncias da morte de Jobim.

O senador estava internado "para ser submetido a um checkup de rotina no Hospital dos Servidores do Estado (Zona Portuária do Rio de Janeiro)".

Pelo que foi possível apurar, a família do Sr. Danton Jobim encontrou e vem encontrando dificuldades até mesmo para obter cópias da documentação hospitalar arquivada no HSE. Chave para uma série de perguntas, o próprio Sr. Luis Jobim [neto de Jobim] lá esteve, por solicitação do autor destas linhas e nada obteve de concreto. Um dos pontos mais emblemáticos sobre o fato em si, é que o senador estava aparentemente bem de saúde e, no apartamento, como testemunha e acompanhante privilegiado na madrugada em que se deu o óbito, apenas o irmão e ex-embaixador, José Jobim. (ARGOLO, 2005, p.18) 
De acordo com Argolo, o irmão de Jobim afirmou ter sido tomado por um sono incontrolável, "sem que tivesse ingerido qualquer medicamento indutor do sono". Quando despertou percebeu que Danton Jobim estava morto. Para o pesquisador, existem suspeitas de que a morte de Jobim possa ter ocorrido, "em circunstâncias ainda não esclarecidas, nos rastros da Operação Condor" ${ }^{\text {. }}$.

As suspeitas também decorrem do fato de que Jobim, naquele momento, era um candidato natural ao governo do Estado do Rio de Janeiro, em contraposição a Antonio de Pádua Chagas Freitas. Antigos aliados, os dois tinham, então, "divergências políticas acirradas", atuando em campos opostos.

A família de Jobim - atualmente empenhada em materializar o Instituto Danton Jobim, no Rio de Janeiro, "destinado a estimular o desenvolvimento de pesquisas sobre o Jornalismo e a política fluminense" (ARGOLO, 2005, p. 19) - busca respostas.

Outro que levanta suspeitas sobre a morte de Jobim é o jornalista Fernando Segismundo ${ }^{6}$, seu companheiro na $A B I$ durante muitos anos.

Houve qualquer coisa estranha com a morte dele. O Danton tinha uma chance muito grande de ser candidato ao governo do Rio contra o candidato Chagas Freitas, que tinha sido padrinho político dele. Ele ganharia do Chagas, com certeza, porque era muito bem quisto. O Danton quis ser político e eu acho que foi um grande erro dele, porque ele era um intelectual.

\footnotetext{
${ }^{5}$ A Operação Condor foi responsável pela morte e desaparecimento de milhares de pessoas na Argentina, Brasil, Chile, Paraguai e Uruguai, resultado de ações violentas "perpetradas pelos agentes do aparato repressivo dos governos” desses países, entre 1954 e 1990 (ARGOLO, 2005).

${ }^{6}$ Em entrevista concedida à autora em 07/09/2005.
} 
Segismundo conta detalhes sobre o dia da internação de Jobim, já que foi ele quem o acompanhou ao Hospital dos Servidores, junto com o filho Renato. Explica estava em Petrópolis quando soube que estava sendo oferecida uma feijoada na casa do Jobim. Acabou indo visitá-lo e disse que percebeu algo estranho na aparência do jornalista. Quando questionou se ele estava se sentindo bem, ouviu que não. "Você fez alguma extravagância, bebeu, não dormiu, alguma coisa?" Jobim disse que havia acordado indisposto. "Coloquei a mão nele percebi uma arritmia muito grande." Segismundo conta que, por sorte, havia um médico no grupo. "Pedi que ele disfarçadamente examinasse Jobim e ele confirmou a arritmia".

O médico disse que era melhor levar Jobim para um hospital no Rio de Janeiro. "Eu estava com meu carro e disse para o Danton que ele estava um com 'probleminha' qualquer, mas que não era bom tratá-lo em Petrópolis. Ele concordou, mas estava falando e andando", explica Segismundo que, junto com sua mulher e com o filho de Jobim, rumou para o Hospital do Servidor Público. "Cheguei lá e expliquei que o Senador da República estava doente, poderia ser uma coisa grave”.

Ele conta ainda que quando foi visitá-lo no quarto, encontrou Jobim recostado na cama lendo um livro em alemão. "Eu perguntei: você está lendo em alemão? E ele respondeu: ‘É, eu gosto muito de alemão’”.

Segismundo, vice-presidente da $A B I$ numa das gestões de Jobim, diz que nunca se conformou com a sua morte. "Ele era um homem 
talentoso, culto. De vez em quando vinha até mim e falava: 'Toma conta da casa $[A B I] "$. 


\section{O pensamento jornalístico de Danton Jobim}

Da mesma forma que propunha ser o texto jornalístico - simples, conciso e objetivo - Danton Jobim pensava o jornalismo. Suas idéias sobre o tema são extremamente atuais, mostrando que ele levantou questões, que até hoje são debatidas academicamente, num momento em que a pesquisa acadêmica ainda não existia no País. Marques de Melo (2004b, p.2-3) explica sua importância naquele cenário:

(...) Danton Jobim, o desbravador da pesquisa jornalística na universidade brasileira, responsável pela primeira plataforma de investigação científica inscrita num curso superior. Foi natural que ele se convertesse no primeiro brasileiro a publicar artigos e livros em centros avançados do saber midiático, ou seja, nos Estados Unidos e na França.

Sobre suas idéias precursoras, Lins da Silva (In: JOBIM, 2003, p.14) diz que "ou Jobim foi muito avançado para o seu tempo ou os jornalistas brasileiros atuais estão muito atrasados para o deles". Pode-se dizer que, mesmo depois de tantos anos, todas as questões levantadas por ele sobre o ensino, a profissão e a técnica do jornalismo ainda são temas de debates, e poucos profissionais e pesquisadores conseguem ter a mesma clareza de pensamento dele. Um exemplo claro é que, na década de 50, Jobim já discutia a questão do pouco tempo disponível para a leitura dos jornais, tema que hoje é constante, principalmente considerando-se as questões levantadas com o surgimento da Internet, rede inimaginável 
naquela época. Dessa forma, discutiremos seu pensamento, dividindo os temas por ele abordado, tomando como base o seu livro "Espírito do Jornalismo", tradução do livro "Introduction au Journalism Contemporaine" editado em Paris em 1957, como resultado de um curso ministrado na França.

\subsection{Jornalismo e opinião pública}

Para Jobim, a opinião pública se forma pela informação, "e esta pressupõe o conhecimento e a interpretação dos fatos”. O contato permanente com os semelhantes é que faz os homens formarem seus juízos, a partir da troca de informações e de idéia. E o jornal é a forma organizada dessa relação.

Por isso mesmo, o jornal precisa levar em conta de que essas relações não podem confundir público e massa. Segundo Jobim, o público "não é homogêneo em sua composição - por força dos diferentes graus de cultura e status social". Admitindo a existência desses vários públicos, e considerando que cada um deles reage "de modo distinto em face da ação que se exerça sobre eles", defendia que os jornais deveriam ser feitos para o "seu público" e não para o público de uma forma geral.

O jornal consegue obter êxito junto aos seus leitores, atingindo um público maior, é o que Jobim denomina de "imprensa de tipo médio", que mantém ao mesmo tempo um padrão conservador e sensacionalista. "E é justamente o seu ecletismo que lhe assegura grande circulação". 
No entanto, não é apenas a grande circulação que garante prestígio à uma publicação. Um jornal pode ter uma "circulação bem mais restrita que a de outro e gozar de maior prestígio que este sobre a opinião das elites dirigentes do país". As opiniões expressas nos editoriais e a política que o jornal sustenta podem se mostrar muito mais eficientes nesse sentido.

Os editoriais, segundo Jobim, não são escritos para o leitor comum. Por isso mesmo, a maioria de leitores também não lê editoriais. As posições que o jornal defende são escritas para uma minoria que é responsável pela liderança da comunidade. Mesmo assim, escritos para poucos, ele considerava que "os mais apreciados, em tempos normais, são os que convidam o leitor a raciocinar, não se dirigindo a ele como se se tratasse de falar a um auditório (...)".

Embora reconhecesse a força política dos editoriais, Jobim reforçava que a notícia concorre com o editorial na formação da opinião pública, embora também a publicidade e as relações públicas tenham o mesmo papel.

Em seu livro, ele repete Harry Truman (apud JOBIM, 2003, p.92), ex-presidente norte-americano que costumava repetir a frase de um político britânico do século XIX: "Dê-me o controle de suas colunas de notícias e pouco me importa quem escreva os seus editorias ou o que estes digam de mim”. Explica que embora Getúlio Vargas e Juscelino Kubitschek não tivessem o apoio dos veículos, foram eleitos da mesma 
forma, porque eram notícia. E o jornal não pode deixar de dar notícias. Sobre isso, Jobim (2003, p.93) escreveu:

No jornal contemporâneo, o homem que se faz notícia, que passa a ocupar um lugar na imaginação e na curiosidade das massas, tem garantidas a repetição constante de seu nome e a publicidade de seus feitos ou palavras.

Mas ele lembrava que, além do jornal, hoje existem outros instrumentos de comunicação com as massas que não a impressa. Para ele, o rádio, a televisão e o cinema são veículos que concorrem com os jornais na transmissão da notícia e que aumentam a "possibilidade do acesso ao público à cena do acontecimento".

Por isso, acreditava ser urgente a proteção do público contra informações que poderiam ser manipuladas por esses meios, principalmente por causa do forte alcance. "Parece evidente a necessidade de proteger esses novos meios de ação sobre a opinião pública, pondo-os a salvo da opressão e da falsificação deliberada".

\subsection{Jornalismo e técnica}

A pressão do tempo sobre o trabalho do jornalista foi causada, segundo Jobim, pelo progresso que as máquinas tiveram na composição e na impressão. Mas ele compreendia que essa inovação mexeu com o 
trabalho da imprensa, forçando o jornalista a encontrar meios de chamar a atenção do leitor.

Os jornalistas deste último meio século tiveram de adotar as suas técnicas de redação e a apresentação da matéria a novas condições, que reclama certos artifícios ou truques para forçar a atenção de um leitor distraído por mil solicitações diferentes (JOBIM, 2003, p.73).

Sobre o texto do repórter, ele afirmava que "ser amável com o leitor é ser conciso, sem prejudicar a riqueza e a objetividade do relato jornalístico". Dessa forma, acreditava que escrevendo dentro de um padrão o estilo repórter melhoraria. Mas reconhecia que o grande "drama do jornalista é que ele não pode se calar quando quer", apontando que escrever pouco era uma das grandes dificuldades do jornalista.

Mas o bom texto não se resumia à concisão. Jobim lutava pela simplicidade de estilo, que acreditava agradar muito mais ao leitor. "Quem é simples no estilo é claro no dizer".

\subsubsection{Editorial}

Sobre o editorial e a opinião no jornalismo, embora reconhecesse sua necessidade, Jobim era extremamente crítico. Ele acreditava que o artigo de fundo ideal talvez seja "aquele que se possa resumir em dois 
parágrafos: o primeiro enunciando a tese, numa frase curta, e o último confirmando-a, numa frase incisiva, que seria a ampliação da primeira”.

As mudanças na redação e a manipulação das notícias dentro do jornal, mereceram dele os seguintes comentários:

\begin{abstract}
As notícias chegam ao público depois de manipuladas no laboratório da redação. Esta deixou de ser um ajuntamento de literatos boêmios para constituir um corpo de trabalhadores especializados em transformar a matéria-prima fato no produto acabado notícia. (...)

O processo de reescrever a matéria não pode ser dispensado numa redação de hoje. Antes de tudo, a valorização do espaço das edições exige que se resumam as notícias. Em segundo lugar, o acúmulo de notícias reclamando a atenção do leitor impõe que se lhe facilite a leitura, estabelecendo uma hierarquia (...).(JOBIM, 2003, p.76-77)
\end{abstract}

Por isso Jobim contestava as novas técnicas de valorização ou dramatização das notícias, sempre buscando o sensacionalismo. Ele achava que esses novos truques de estilo não levavam à melhor informação. Pelo contrário, faziam com que os jornalistas se afastassem cada vez mais da informação correta e exata.

\title{
3.2.2 Estilo
}

Sobre o estilo no jornal, Jobim dizia que não existe uma linguagem especial. Novamente, apelava para uma linguagem simples que pudesse levar o leitor à compreensão dos fatos: 
Aos focas, ou seja, aos aprendizes de repórteres, ensinam eles uma dúzia de chavões, que consideram "estilo de jornal". $\mathrm{Na}$ verdade, não há uma linguagem de jornal. $O$ jornalista não escreve numa língua especial, mas no bom português, no bom francês, no bom inglês ... tão bom quanto lhe permita o domínio da língua e a necessidade da improvisação. (JOBIM, 2003, p.50)

Estilo jornalístico, para ele, era o jornalista se colocar no papel do leitor do jornal e imaginar o que ele gostaria de ler: “(...) é mera questão de approach, ou seja, do ângulo em que nos colocamos e presumimos ser o do leitor do jornal. Nesse sentido estrito, mas só nele, é aceitável a sua existência".

Mas Jobim era um crítico feroz do jornalista que procurava fazer do jornal seu espaço de experiências estilísticas. Por isso, a recomendação de que o escritor que se fazia jornalista deveria resistir "à tentação de usar o jornal como campo de provas de teorias e estilos".

Sua preocupação com a facilitação do entendimento do texto fazia com que buscasse uma simplificação quase esquemática do conteúdo e de forma. Para ele, o texto:

Requer uma ordem, nem sempre lógica, no dispor os elementos de uma narrativa, que visa introduzir o leitor na essência da matéria logo que Ihe inicia a leitura. E, além disso, mais três qualidades: concisão, concisão, concisão. (JOBIM, 2003, p.51) 
Por essa razão, Jobim, junto com Pompeu de Souza, introduziu o Manual de Redação no Diário Carioca. Defendia a forma norte-americana de formar escritores por meio de manuais de estilo e de criar para seus jornalistas o Style Book. Acreditava que cada redação deveria possuir "o compêndio de regras para bem escrever, na opinião do diretor do jornal", evitando, dessa forma que, por meio dessas normas o trabalho jornalístico se convertesse em literário, embora defendesse a possibilidade de o texto jornalístico ser um texto autoral.

(...) é uma tentativa louvabilíssima para elevar o nível do relato jornalístico. (...) O Style Book não elimina, como se tem pretendido, a chance de que a obra do repórter atinja o nível da criação artística. (JOBIM, 2003, p.52)

\subsection{Imprensa norte-americana versus imprensa latino-americana}

Para Jobim, a imprensa americana atingiu um alto padrão de objetividade porque foi tratada como indústria. "Os EUA são o único país onde os jornalistas não se envergonham de confessar que sua atividade não é desinteressada, mas faz parte de um negócio, um business".

Ele defendia o entendimento de que o jornal é uma empresa comercial e como tal deve ser tratado. Isso não invalidaria sua função social de informar o público e deixar que ele formasse sua própria opinião sobre fatos de interesse geral. Insistia que o jornalismo não era uma religião e que o jornalista não era um sacerdote. Compreendia que o poder 
do dinheiro tinha influência no jornal, mas que sua existência e sua força estavam cada vez mais vinculadas à força financeira que conseguisse.

Já na América Latina, Jobim apontava a existência de um certo purismo em relação ao jornal: “(...) ninguém funda um jornal para negócio, para fazer dinheiro. Ele pode vir como um inesperado dividendo, normalmente ele é fundado para fins políticos".

Ele exemplifica com o caso do próprio Diário Carioca que se viu fechado várias vezes em época de agitação política. Cita também os casos de O Estado de S. Paulo e La Prensa, que desafiaram a ditadura: "o primeiro apropriou-se, por compra forçada, de 1940 a 1946; o segundo foi expropriado e só voltou ao seu dono depois da queda de Perón”.

Sobre o imaginário popular acerca da função do jornal, Jobim dizia que o povo acredita que "o jornal tem um destino heróico a cumprir", e que a imprensa tem a função de defesa do cidadão. "Trabalhadores e estudantes quando se vêem ameaçados nos seus interesses, vão para o jornal".

A imagem idealista que se fazia do jornal permanecia na mente das pessoas, mesmo com todo o processo de modernização por que passava a imprensa da época. 


\section{4 Ética na imprensa}

Refletindo ainda sobre a questão comercial do jornal, Jobim insistia que "a imprensa é obra de homens, não de anjos" e que, pela sua própria natureza, a informação jornalística tem um caráter superficial, em razão de seu processamento dentro de um tempo específico.

Reconhecia que era impossível publicar um fato depois que ele tivesse sido inteiramente apurado. Se assim fosse, acreditava que não haveria jornalismo. Mas isso não impedia o repórter de buscar "a verdade pela objetividade das notícias". Para Jobim, embora nenhum jornal pudesse realizar plenamente tal façanha, deveria perseguir esse ideal.

O que se pode exigir de um jornal é que ele seja honesto com seus leitores, os quais, aliás, não esperam dele que façam milagres e Ihes apresente um quadro impecável, irretocável, irretratável, das coisas que sucedem na cidade, no país e no mundo. $\mathrm{O}$ que se pode pedir do jornalista é que não use de má fé com seu público, induzindo-o a erro em matéria de fato, seja pela falsificação das notícias, seja pela sua omissão. (JOBIM, 2003, p.56)

Porém, não acreditava em uma "ética jornalística". O jornalista deve estar ligado com os padrões éticos de seu tempo, seguindo a profissão com a mesma ética que emprega em sua vida particular. Para Jobim, o homem é ético ou não é. Isso é que vai definir sua ética profissional. 
Reconhecia, no entanto, que "mais que nenhuma outra pessoa, o jornalista comete erros e injustiças". A necessária rapidez com que tem de apurar e escrever faz com que seus juízos sejam apressados. Mas o importante é que o jornalista tenha dignidade para perceber e corrigir esses erros. "Humildade para o 'mea culpa' e coragem para a correção de suas faltas, eis uma virtude indispensável”.

Virtude que aparentemente não parece ser tão incentivada, como aponta Lacan:

$\mathrm{O}$ jornalista que reconhece ter se enganado se coloca em perigo. Não em relação ao público, mas à sua hierarquia. Os responsáveis de um jornal, de uma rádio ou de uma televisão, são sempre persuadidos que é o médium quem paga, em perda de imagem e audiência, o erro do jornalista. (LACAN apud MARCONDES FILHO, 2002, p. 70)

Mas, segundo Jobim, o leitor "conhece as fraquezas e eficiências do jornal num regime de imprensa livre". Mesmo assim, prefere a imprensa dentro dessa realidade do que substituída por uma controlada.

\subsection{Jornalismo e literatura}

O jornalista, mesmo no chamado mundo livre, tem a sua atividade crítica estreitamente balizada por uma série de tabus políticos, morais e materiais, de que o escritor já se libertou. (JOBIM, 2003, p.44) 
A defesa que Jobim faz do Manual de Redação está vinculada principalmente com sua idéia de que jornalismo não é literatura, embora reconheça que a reportagem, o editorial e a crônica poderão ser escritos de forma harmônica e prazerosa. Apesar de atuarem com assuntos ligados com o humano, ele deixa claro que para o jornalismo só existem os fatos que interessam, ao contrário da literatura.

Por tudo isso é que o jornalista não deve ter a preocupação de apurar tão bem sua linguagem como um escritor. Para justificar cita a frase do ensaísta Aires da Mata Machado Filho:

\begin{abstract}
Não passa pela cabeça do jornalista guardar as palavras de cada dia, ao passo que o escritor que se preza não sossega enquanto não 'enfeixa em livro' as suas páginas, sempre elaboradas com a secreta intenção de perdurar. (MACHADO FILHO, apud JOBIM, 2003, p.43)
\end{abstract}

Jobim não poupava críticas ao jornalista que se excedia na preocupação em escrever bem. Para ele, geralmente é um "escritor que não se realizou". E achava que, nessas circunstâncias, o jornalista deveria abandonar a profissão e buscar seguir carreira de escritor.

Porém reconhecia a profunda influência que o jornalismo tem sobre a literatura e vice-versa. No entanto, acreditava que o jornalismo influencia muito mais a literatura do que o contrário, "em que pese a interação inevitável de ambos". E justificava: 
Quem não descobre à primeira vista nos grandes poetas Garcia Lorca, ou exemplo, ou os nossos Carlos Drummond de Andrade e Manuel Bandeira - o vinco da influência jornalística? Mostraram eles em muitas de suas produções como se pode captar a poesia das humildes ocorrências de rua ou de polícia sem afastar-se, mesmo, do estilo do repórter. (JOBIM, 2003, p.48)

\subsection{Jornalismo e História}

Da mesma forma que mostra as diferenças entre jornalismo e literatura, Jobim explica a diferença entre jornalismo e história, para quem "o passado mais recente, o passado imediatamente anterior a hoje, o passado de ontem, este não é história, é jornalismo".

Acredita, sim, que os jornais serão, no futuro, uma fundamental fonte de pesquisa para os historiadores, tanto nas suas grandes reportagens como nas pequenas notas que contam sobre a vida em sociedade. E quanto mais exata a notícia, mais ela servirá como instrumento de apoio para o historiador entender uma época.

Mas insiste que a pretensão do jornalista não deve ser fazer história:

Faz, mas não escreve, limitando-se a fornecer aos historiadores os fatos concretos - pedra e tijolos que, ligados a materiais de outras origens, vão permitir as grandes obras interpretativas. (JOBIM, 2003, p. 37) 
Posição semelhante defendia Luiz Beltrão, lembrando que a "atualidade é a característica dominante do jornalismo". Beltrão recorre a Herráiz:

\begin{abstract}
A atualidade é o presente, o que ocorre sobre a marcha do tempo, o que sucede atualmente ou o que, havendo sucedido, atua sobre a consciência do hoje. O anterior pertence à história, não ao jornalismo que, por essência, vive sobre o momento, informando sobre o presente e fixando-o para o futuro. (HERRÁlZ, apud BELTRÃO, 2003, p. 70)
\end{abstract}

Para Beltrão, o jornalismo já não existe quando a história começa.

Da mesma forma, Carlos Rizzini e Alceu Amoroso Lima também concordam que não é intenção do jornalista fazer história, porque não é historiador o homem que narra o que viu, por ser um conhecimento difuso e superficial. Somente com a perspectiva do tempo é que os fatos podem ser analisados em profundidade.

E Jobim (2003, p.37) acrescenta, alfinetando ainda a opinião no jornal:

$E$, por estranho que parece, não é o editorialista, com suas idéias, seus preconceitos e suas paixões, o que terá lugar de honra nos laboratórios de pesquisas histórico-sociais. Este lugar pertencerá ao repórter, que procura ser impessoal e isento nos seus relatos. 


\section{A escola de jornalismo no Diário Carioca}

"A reforma revolucionou o jornalismo impresso brasileiro"

Danton Jobim

Não era uma redação como outra qualquer. Nem podia ser. O contínuo era Angenor de Oliveira, o Cartola, um dos maiores compositores da música brasileira de todos os tempos que, junto com mais seis amigos, criou a primeira escola de samba do subúrbio carioca - a Estação Primeira de Mangueira.

Os focas da redação seriam os grandes nomes do jornalismo brasileiro nas décadas seguintes. Por lá passaram Evandro Carlos de Andrade, Armando Nogueira, Paulo Francis, Zuenir Ventura, entre outros grandes jornalistas que se destacaram na imprensa brasileira. O salário sempre atrasava, mas o jornal era a prolongação da casa de muitos deles.

Era uma redação coesa, afinada, que convivia em um ambiente de "absoluta cordialidade" e com muita liberdade de trabalho. José Louzeiro, um desses jornalistas formados pelo Diário Carioca, conta o que os atraía tanto em uma redação onde o dia do pagamento era uma incógnita: "Por lá afinávamos nosso texto; aprendíamos a escrever e tudo isso num clima de camaradagem, de humildade, com mestres fingindo que, também, aprendiam conosco" (LOUZEIRO In: DIÁRIO CARIOCA, 2003, p.77).

Esse era o Diário Carioca (Anexo A) na década de 50: uma escola de jornalismo com grandes mestres que formaram grandes alunos e que 
também se tornariam professores na arte da escrita do jornalismo. Mas essa escola não nasceu junto com o jornal, que foi criado, como tantos outros em sua época, para marcar uma posição política.

No caso do Diário Carioca, fundado em 17 de julho de 1928 por José Eduardo de Macedo Soares, a finalidade era fazer oposição ao governo do presidente Washington Luís, embora, para seu fundador, o objetivo do jornal fosse:

(...) Servir ao país, traduzindo lealmente seus sentimentos, esclarecendo e interpretando as correntes de opinião, e assumindo com honestidade e firmeza a parcela de responsabilidade que the coubesse nas lutas da política brasileira. (MACEDO SOARES apud ABREU et al., 2001, p. 1840)

Macedo Soares, membro de tradicional família política do Estado do Rio de Janeiro, havia deixado a Marinha, no posto de primeiro-tenente, para se dedicar à política e à imprensa. Em 1912, já havia fundado o jornal O Imparcial, primeiro jornal carioca a publicar ilustrações, que fazia oposição ao presidente Hermes da Fonseca. O jornal foi fechado em 1924, quando o presidente da República decretou estado de sítio e seu proprietário preso.

Eleito deputado federal pelo Partido Republicano Fluminense em 1915, Macedo Soares foi reeleito por duas vezes, permanecendo no cargo até 1923. Sua trajetória na imprensa representou bem sua ligação política, 
e conseqüentes rompimentos, em diferentes momentos da sociedade brasileira.

O Diário Carioca refletia essa característica de jornalismo de combate, crítico e de opinião. Quando Danton Jobim entrou no jornal, em 1932, tornou-se o principal aprendiz de Macedo Soares.

Ele me tomou pela mão, como disse Negrão de Lima $^{7}$, para ensinar-me a rota, na íngreme escalada, orientando-me sobre os segredos do seu ofício, aprendido no convívio com Rui [Barbosa] e no dos mestres franceses e em muitos anos de dura experiência e sacrifício a que nem mesmo faltaram as agruras do exílio. (JOBIM In: O GLOBO, 1973)

$\mathrm{Na}$ verdade, Jobim sentia-se um verdadeiro discípulo de Macedo Soares. Dele herdou a tendência liberalista e uma hábil capacidade de negociador que permeou sua carreira política e jornalística.

Sobre mim foi derramando prodigiosamente lições de mestre que o discípulo, na pobreza de seus dons, pouco soube aproveitar. Mais do que tudo, porém, foi-me dado o nobre exemplo. $\mathrm{O}$ da coragem moral. Do orgulhoso amor à missão do jornalista. Da paixão da liberdade, que brotava, espontânea, do seu horror visceral a todas as formas de opressão e a todas as injustiças. (JOBIM In: O GLOBO, 1973)

\footnotetext{
${ }^{7}$ Francisco Negrão de Lima foi ministro da Justiça do segundo governo Vargas, prefeito do Distrito Federal e ministro das Relações Exteriores no governo de Juscelino Kubitschek. Eleito governador do Estado da Guanabara em 1965, em pleno regime militar, sua eleição foi considerada um duro golpe à ditadura.
} 
Jobim entrou no Diário Carioca como redator político. Anos depois, como diretor de redação, começou a mais importante reforma no jornalismo brasileiro, resultado de suas viagens ao exterior, em companhia de seu secretário de redação, Pompeu de Souza, e de seu chefe de reportagem, Luís Paulistano.

Era início do ano de 1950. Danton Jobim e Pompeu de Souza arregimentaram um grupo de jovens, vindos quase todos de diferentes cursos universitários, para introduzir no Brasil as técnicas de redação originalmente desenvolvidas nos Estados Unidos.

Foi nessa década que um grupo de jornalistas altamente qualificados do Diário Carioca, jornal inovador no uso do lead e o primeiro a empregar equipe de copidesque em sua redação, começou a desempenhar papel de formador de novos quadros para a imprensa. (ABREU et al, 1996, p.15)

A aspiração de modernidade adequava-se ao espírito desenvolvimentista da década e correspondia à influência do estilo das agências de notícias internacionais (France Press, United Press, Associated Press, principalmente), cujos telegramas traduzidos os jornais transcreviam. Com a Segunda Guerra Mundial e, em seguida, a Guerra Fria, esses telegramas ocupavam espaços privilegiados, em conflito estilístico claro com as matérias locais.

Até então, o modelo do jornalismo brasileiro seguia predominantemente o modelo francês. O próprio Jobim confirmava que essa era a influência mais importante. "A imprensa francesa tem servido 
de modelo para a imprensa brasileira por mais de meio século", dizia ele em 1954. Misturavam-se o jornalismo de opinião com o jornal popular, com espaços destinados às crônicas e à publicação de folhetins. A política era apresentada numa linguagem pouco objetiva. Mas isso precisava mudar e a imprensa se adequar aos novos tempos.

Por outro lado, as técnicas modernas de redação eram conhecidas por um número restrito de jornalistas com experiência no exterior. Casos como de Joel Silveira e Rubem Braga, correspondentes de guerra junto à Força Expedicionária Brasileira, na Itália, ou o próprio Pompeu de Souza, que trabalhou como redator de um noticiário da Columbia Broadcasting System (CBS) dirigido ao Brasil, entre 1941 e 1943.

Pompeu de Souza explica como era a sua percepção desse "novo" jornalismo durante a estada nos Estados Unidos:

Infelizmente não pude freqüentar redações de jornais, porque eu estava fazendo rádio intensamente. Mas lia muito os jornais americanos, e foi então que eu comecei a verificar que eles tinham uma diferença fundamental em relação aos brasileiros: eram escritos com objetividade, a notícia era só notícia, era só informação, pois as opiniões eram veiculadas nos editoriais. Hoje, entretanto, sabemos que isso é muito relativo. (SOUZA apud LINS DA SILVA, 1991, p. 78)

Segundo ele, desde sua volta ao Brasil, em 1943, começou a fazer pequenas modificações no Diário Carioca, "objetivando um jornalismo mais dinâmico". Mas as introduções não eram significativas. Tampouco foi 
criada a figura do copidesque, que representou o centro da mudança em 1950.

"Era automático. No Diário Carioca reescrevia-se tudo, o que era um pouco a cabeça do [Luís] Paulistano", contou em entrevista Evandro Carlos de Andrade (ABREU et al 2003, p. 23). E foi esse modelo norteamericano, que privilegiava a informação, que gradativamente foi substituindo o anterior.

No Diário Carioca o repórter também fazia de tudo um pouco. Cobria diferentes setores, fato comum em jornais do seu porte. Mas a grande chance para o jornalista naquele período era cobrir política. Essa era a forma de se aproximar de políticos de sucesso e conseguir um salário complementar que Ihe garantisse a sobrevivência. "Naquele tempo, o jornalista completava o ordenado com um emprego público", explicou Andrade. Principalmente em um jornal onde os vales semanais "não eram pagos semanalmente".

Evandro Carlos de Andrade explica essa aparente incoerência ou falta de ética profissional, lembrando a situação profissional do jornalista na época: 
fusca igual ao do Paulistano. Aquilo era o êxito na profissão. (ANDRADE apud ABREU, 2003, p.57-58)

Vida de jornalista não era fácil naqueles tempos. Jornalismo era bico. Mas tinha lá seu lado interessante e divertido. E tinha a devoção com que era feito no Diário Carioca. O repórter Araquém Moura, que também ingressou no jornal na década de 50 cobrindo polícia e depois foi secretário do DC-Brasília, confirma:

Toda a equipe - direção, chefias e subalternos - era uma grande família. Mesmo nas ocasiões em que os salários atrasavam, a notícia era sempre o mais importante para todos. (MOURA In: DIÁRIO CARIOCA, 2003, p. 57)

O bom humor da redação superava todos os percalços econômicos. Embora muitos também trabalhassem em outros jornais, ninguém queria faltar na redação do Diário. Louzeiro conta algumas das brincadeiras que elevavam o ânimo dos jornalistas:

Dedé Maia e Everardo Guilhón extrapolavam os papéis de secretários de redação: a par das tarefas normais, comportavam-se como "animadores da redação", onde encenavam verdadeiros esquetes. Se havia uma visita na hora em que se iniciava o "drama de fechamento", o que poderia importar em atraso de rodada, eis que os dois promoviam inesperada discussão, falsamente dramática. Em meio às palavras ásperas e até alguns palavrões, eis que Guilhón sacava um punhal e avançava na direção de Dedé, sendo contido por Catão, Jotaefegê e o contínuo Cartola que, cúmplices da brincadeira, agiam com a maior seriedade. (LOUZEIRO In: DIÁRIO CARIOCA, 2003, p. 77-78) 
A forma de expulsar as visitas alegrava a todos na redação, que caíam no riso. Cartola, por sinal, protagonizou outra cena de humor no jornal, também contada por Louzeiro.

Por trás da mesa do redator-chefe do jornal uma parede era usada como "agenda coletiva", com inúmeras anotações feitas a lápis, números de telefone e recortes de jornais com eventos que seriam pauta do jornal. Quando Ascendino Leite, escritor de renome, assumiu a chefia de redação mandou, durante um final de semana, pintar a tal parede. Na segundafeira, os jornalistas, espantados, resolveram demonstrar a revolta por não terem sido avisados da medida.

Acontece que, certa noite, início do expediente, eis que Dedé Maia determina que o contínuo, Cartola (o compositor), inaugurasse o "mural" com determinado número de telefone.

Cartola subiu num banquinho e lá estava escrevendo, com um lápis bicolor, quando foi surpreendido por Ascendino, que chegou silencioso, ficou alguns instantes acompanhando o que considerava imprudência e, mais do que isso, uma afronta. Ferido no seu orgulho, o redator-chefe ajustou os óculos, esbravejou:

- O que é isso, seu Cartola? Por acaso o senhor pensa estar no seu barraco?

- Não, senhor. No meu barraco, eu tenho um caderninho pra fazer anotações. (LOUZEIRO In: DIÁRIO CARIOCA, 2003, p. 79)

Era o bom humor que fazia com que eles fugissem do "jornalismo burocrático, sem sal e sem vida". Mas um jornalismo com toda a seriedade possível. 


\begin{abstract}
$\mathrm{Na}$ nossa loucura, tínhamos comprometimento com o que escrevíamos; havia coragem de dizer e assumir as culpas quando surgiam os processos por crime de imprensa ou os enfrentamentos com a polícia. (LOUZEIRO In: DIÁRIO CARIOCA, 2003, p. 80)
\end{abstract}

Outro jornalista que acumulou a função pública - trabalhava na Assessoria de Imprensa da Presidência da República no governo de João Goulart - com a de redator do Diário Carioca foi Carlos Castelo Branco. Foi para lá quando o jornal já entrava em decadência, mas conta que "ali, apesar das dificuldades, tudo era feito com humor, competência e amor. Ou quase tudo". Também para Castelo Branco, o que mais impressionou foi a convivência com o que ele chamou de "celeiro de talentos que lhe sobreviveriam com louvor em todas as áreas de atividades intelectuais e políticas".

Na redação do jornal os estilos eram diferentes. Pompeu de Souza, movido pela paixão, costumava dar gritos com os repórteres. Luís Paulistano, mais contido, gostava de conversar com seus comandados pelos cantos, chamando sempre para uma conversa reservada. E o Danton Jobim? "A cabeça criativa era mesmo a de Pompeu. Danton era o cérebro político do jornal”, afirmou Milton Coelho da Graça ${ }^{8}$. Nilson Lage discorda:

\footnotetext{
${ }^{8}$ Em entrevista à autora.
} 
(...) Pompeu confessou que apenas compreendeu as normas do estilo jornalístico moderno em 1949, quando lecionava, como assistente de Danton Jobim, na Universidade do Brasil. (...) e Pompeu sempre esteve longe de ser modesto (...). (LAGE, 2004, p.12)

Ana Arruda Callado ${ }^{9}$, primeira mulher a assumir o cargo de chefe de reportagem de um jornal brasileiro, o Diário Carioca, concorda:

\begin{abstract}
A explicação do Sérgio Buarque de Holanda de que para o brasileiro as coisas não são racionais, são simpatias, antipatias ou de laços familiares e laços afetivos, essa teoria sobre o homem cordial explica um pouco porque Danton Jobim não é conhecido entre os estudiosos de jornalismo e entre os jornalistas do Brasil. O Danton só passava pela redação, morria de preguiça. (...) O Pompeu era o cérebro do jornal, só que o Danton tinha dado ao Pompeu de bandeja tudo aquilo.
\end{abstract}

Ana Arruda, que foi aluna de Jobim na Universidade do Brasil, explica que só entendeu isso muito mais tarde, quando se preparava para dar aulas e leu o livro "Espírito do Jornalismo".

Percebi o que eu tinha perdido na faculdade. Descobri que ele sabia tudo que eu tinha aprendido na prática, que eu tinha lido, que eu tinha conversado com pessoas mais experientes. Lendo aquele livro do Danton, as conferências e mais aquele projeto de curso é que descobri que ele é o pioneiro absoluto dos cursos de jornalismo no Brasil (nesse sentido, não de luta pela implantação, o que a $A B I$ fez desde seu início). Nós conhecemos a história dos cursos, mas sobre a implantação, o estudo, o que aconteceu, tanto na introdução das técnicas modernas, as técnicas norte-americanas que realmente modernizaram o jornalismo brasileiro... Então, quem fez os currículos? Pompeu. E quem introduziu o manual de redação? Pompeu. Mas se você pega a data da conferência do doutor (Jobim), você vê que a criação foi dele. Aliás, como escrevia bem!

Tudo isso, segundo a jornalista, devia-se ao comportamento de Jobim, que não era tão cativante como o do Pompeu de Souza. Na época

\footnotetext{
${ }^{9}$ Em entrevista à autora em 20/12/06.
} 
em que o conheceu, parecia sempre muito mais preocupado com a política, com um jeito displicente para as outras atividades. Havia ainda a questão da política. "Ele era do PSD, era conservador. Então, era esnobado pela gente". Ana Arruda explica que na Universidade, assim como no jornalismo, só tinha prestígio quem pertencia à esquerda. Embora reconheça que o ar de tédio do professor tenha contribuído com a impressão guardada, hoje se recrimina por ter dado pouco atenção às suas aulas. Reconhece que ele era o grande pensador do jornalismo naquele período.

O Pompeu levou o louro. Não é que o Pompeu não tenha valor; ele foi um maravilhoso jornalista e, principalmente, um maravilhoso chefe. Ele formou muitos jornalistas. Já o Danton não estava nem aí para isso, não estava nem ligando para as pessoas. Mas foi ele quem pensou e trouxe as novas técnicas. O Pompeu estava lá todos os dias com os jornalistas, ensinando, mas o diretor do jornal era o Danton. Quem foi à Universidade de Colúmbia antes, quem deu conferência lá antes de estudar foi o Danton. Não há dúvida.

Tal opinião é semelhante à de Fernando Segismundo, para quem o papel de Jobim era de orientador de grandes jornalistas do Diário Carioca, que se encarregaram de passar adiante os ensinamentos recebidos.

Danton exerceria uma influência destacada na renovação da imprensa brasileira a partir da revolução técnica operada no "Diário Carioca", onde foi o iniciador e o mestre de alguns mestres do jornalismo como Pompeu de Souza, que começou há 38 anos no velho DC, sob sua orientação. Este seu papel de renovador tinha antecedentes sólidos, que remontam a seu início na profissão, na década de 20 , e à sua participação em "A Manhã", de Mário Rodrigues. Já então, Danton era um estilista na arte de escrever e um técnico em arte gráfica: ele escrevia os textos e depois descia à oficina para paginar o jornal na rama, manchando os dedos de tinta. No "Diário Carioca", mais tarde, fez apenas aprofundar uma vocação e uma destinação que o acompanhavam desde sua iniciação na vida da imprensa. (SEGISMUNDO, In: BOLETIM DA ABI, março de 1978, p. 12) 
Esse interesse dele pelo aspecto gráfico das publicações era tão grande que seu filho, Renato Jobim, contou que o pai costumava guardar fac-símile de páginas de jornal.

Mas foi Pompeu de Souza que redigiu, no carnaval de 1950, o manual de redação, ou as Regras de Redação do Diário Carioca, como foi chamado, embora Ana Arruda Callado atribua a criação a Jobim: "ele pegou o style book e colocou na mão do Pompeu". Um folheto de 16 páginas resumia as disposições que desejavam padronizar a linguagem do jornal dentro de normas de concisão e objetividade, que davam suporte ao slogan então adotado: "O máximo de jornal no mínimo de espaço".

No fundo, o que o redator-chefe, Danton Jobim, juntamente com Pompeu de Souza na chefia de redação, e Luiz Paulistano, na reportagem, procuravam conseguir era a adaptação do ideal configurado na moderna técnica do jornalismo norte-americano, através da obediência dos redatores às regras básicas do chamado lide. (TINHORÃO In DIÁRIO CARIOCA, 2003, p.81)

Embora buscasse organizar a linguagem jornalística, a aplicação das regras devia-se mais à grande capacidade dos profissionais que ali trabalhavam de absorver o conhecimento de seus mestres do que a uma organização estabelecida. José Ramos Tinhorão explica:

Relembrada assim - por sinal de forma tão obediente às tais regras de redação - é possível imaginar hoje, 50 anos depois do acontecimento, que essa tal "revolução na imprensa carioca" aconteceu em clima de alguma seriedade acadêmica, com teóricos de linguagem jornalística expondo princípios a alunos tentando aplicá-los na prática da comunicação escrita. Nada 
mais ilusório. Aliás, se se pudesse contrariar um pouco uma das regras básicas do style book - "evitar palavras chulas e expressões de gíria" - não seria impróprio dizer que todo aquele trabalho coletivo de reformulação da linguagem jornalística transcorria num clima de autêntica esculhambação. (TINHORÃO In: DIÁRIO CARIOCA, 2003, p.81-82)

Opinião parecida com a de Milton Coelho da Graça:

Foi um jornal-escola, pioneiro em técnicas de texto e diagramação. E sempre um pouco louco, porque a criatividade, a alegria e a própria natureza da profissão jornalística freqüentemente parecem extravasar os limites da razão (...) (COELHO DA GRAÇA In: DIÁRIO CARIOCA, 2003, p. 91)

Mas, como confessa o próprio Tinhorão, dentro de uma loucura e uma "bagunça organizada", em que as regras eram de fato aplicadas, embora reconhecido o direito de, vez ou outra, fugir dos moldes estabelecidos, se encaixando no que ele chamou de "atrevimento criativo". Uma criatividade que era louvável, segundo Jobim:

E esse fato nos mostra que os processos de redação jornalística, mesmo onde esta chegou a um alto grau de especialização, como nos Estados Unidos, não opõem o jornalismo à literatura. Clareza simplicidade e concisão no dizer, objetividade no descrever as coisas e o comportamento dos homens - serão porventura, qualidades do estilo jornalístico ou do estilo literário?

Ambos os estilos se confundem; seria impossível traçar com nitidez a linha de demarcação entre o mundo jornalístico e o literário. Esta linha tênue e hesitante marcará, sem dúvida, a diferença de ângulo em que se colocam o repórter e o romancista, o editorialista e o ensaísta - um voltado para as exigências imediatas e transitórias do grande público, outro debruçado sobre os temas universais e permanentes que nascem da natureza do homem e do mistério da vida. (JOBIM, 2003, p. 53) 
O "não elimina, como se tem pretendido" citado por Jobim devia-se às críticas recebidas por Pompeu de Souza, em razão da elaboração do manual. Boa parte da classe jornalística de então rejeitou as mudanças. Ele chegou a ser chamado por Nelson Rodrigues de "o pai dos idiotas da objetividade". Pompeu contou que ele não o perdoava por haver "suprimido dos títulos os pontos de exclamação". O mesmo aconteceu com Osório Borba, que o criticou por deformar o jornalismo e a língua, "acabando com o verbo e suprimindo os artigos".

Lage comenta as características da reforma do Diário Carioca:

\begin{abstract}
Nascida da experiência acadêmica de Danton Jobim e Pompeu de Souza - o primeiro catedrático e o segundo, seu assistente, na cadeira de Técnica de Jornal e Periódico do curso de Jornalismo da Faculdade de Filosofia da Universidade do Brasil (hoje, Universidade Federal do Rio de Janeiro) - a técnica de redação jornalística introduzida pelo Diário Carioca incorporou ao lead americano (mais próximo, no estilo, dos jornais ingleses da época, com períodos um tanto mais longos) uma série de inovações introduzidas na linguagem literária pelos modernistas de 1922. Entre elas, a eliminação de adjetivos inúteis, o combate aos chavões, o uso de preposições mais próximo da linguagem falada e a supressão, paulatina mas constante, das formas arcaicas de tratamento e referência ('doutor', 'eminente jurista', 'sua excelência') e do jargão jurídico dominante em uma profissão até então exercida freqüentemente por bacharéis em Direito, quando não contagiada de rábula de policiais $e$ bandidos. (LAGE, 2004, p.8-9)
\end{abstract}

Aos redatores do Diário era sugerida constantemente a leitura dos autores modernos, particularmente de Graciliano Ramos, cujo estilo enxuto tomava-se como modelo. Na fase de decadência do jornal, eles 
levaram o novo estilo para o Jornal do Brasil, veículo tradicional (fundado em 1891, com orientação monarquista) que se decidiu a fazer uma reforma editorial.

Lá, no final da década de 50 e nos primeiros anos da de 60, o estilo de texto se fixou, associando-se a uma nova estética gráfica e acabou servindo de modelo para a imprensa de todo o país.

Anos depois de toda essa transformação, o Diário Carioca acabou. Por que um jornal tão revolucionário acabou? Alberto Dines (ABREU, 2003) acha que foi porque o Rio de Janeiro ficou "um pouquinho mais apertado e não havia espaço para tanto jornal". Principalmente porque a cidade não era mais a capital federal, a força econômica estava centralizada em São Paulo e porque os jornais não tinham a mesma estrutura de, por exemplo, o Jornal do Brasil. Faltavam anúncios para todos.

Evandro Carlos de Andrade (ABREU, 2003) acreditava que o problema foi decorrente da incapacidade empresarial, no momento em que a comunicação se tornou um grande negócio. "Eles eram homens de jornal, homens de combate, homens de opinião". Existia uma grande distância entre o ideal de se fazer o jornalismo e o caixa necessário para, no final do mês, se pagar os salários, o papel e a tinta. Da mesma opinião compartilha Lins da Silva (1991, p. 78), quando diz que Danton Jobim e Pompeu de Souza perderam a batalha do Diário Carioca, que, "apesar de ter sido um sucesso de vendas, teve de sair do mercado devido a problemas administrativos". 
O caso é que o encerramento das atividades do Diário Carioca abalou a equipe que o compunha e até mesmo as que já tinham saído de lá na época do fechamento. Afinal, além de grande escola de jornalismo, "era um curso de doutorado em convívio humano", como afirmou Renato Jobim (In: DIÁRIO CARIOCA, 2003, p.100), contando de sua nostalgia com o fim do jornal; ou Nilo Dantas, que se emociona ao dizer que, entre as muitas graças que Deus lhe deu, conviver e aprender com os companheiros do Diário Carioca foi a "mais preciosa".

Jorge Guilherme Pontes conta que até houve tentativas de se ressuscitar o jornal, mas que isso seria impossível:

(...) O jornal parou de existir sem que houvesse um tempo de viver um novo momento da imprensa brasileira, onde a administração, as finanças, os interesses comerciais seriam mais importantes do que os textos, a notícia, as verdades e o amor pelo jornalismo. O jornalismo hoje é um negócio que precisa dar lucro. O DC não viveu esse momento nem essa exigência; e, ao profissional, era permitido agregar um pouco de paixão à apuração e ao texto que iria oferecer aos seus leitores. (PONTES In: DIÁRIO CARIOCA, 2003, p. 76)

Mas Pontes confirma que a saudade deixada deve-se à sua vocação de transformar "focas em experientes profissionais", requisitados por outras empresas de comunicação justamente pela formação recebida no jornal.

Mas é José Louzeiro quem recorda a última noite do jornal: 
Certa noite, quando já estávamos quase todos, do antigo copidesque do DC, em outras redações, eis que somos convocados por Dedé Maia para celebração inédita: velório pelo DC que havia morrido, na manhã seguinte estaria enterrado e, por isso mesmo, fora das bancas. Na sobreloja da Avenida Rio Branco, choramos, fizemos discursos e, para completar a cerimônia, fomos para o Bar Flórida, no Edifício A Noite, na Praça Mauá, onde enchemos a cara. (LOUZEIRO In: DIÁRIO CARIOCA, 2003, p.80)

O Diário Carioca circulou pela última vez em 31 de dezembro de 1965. 


\section{A pedagogia do jornalismo, segundo Danton Jobim}

A partir de sua experiência com o treinamento de focas no Diário Carioca e no curso de Jornalismo da Universidade do Brasil, Danton Jobim elaborou sua proposta de pedagogia para jornalismo. Seu manual inexiste nas bibliotecas brasileiras, incluindo-se aí as principais: Biblioteca Nacional do Rio de Janeiro e biblioteca da Escola de Comunicações e Artes da Universidade de São Paulo. O resgate desse material só foi possível graças ao arquivo pessoal do professor Marques de Melo.

Visando estruturar a proposta de Jobim com um modelo pedagógico, analisaremos seu manual a partir dos seguintes pontos: o objeto de estudo, o aluno de jornalismo, o professor, o currículo e o método de ensino.

\subsection{0 objeto do ensino do jornalismo}

Qual a finalidade do ensino do jornalismo? Jobim parte desse questionamento para iniciar uma discussão sobre o tema, buscando, a partir daí, elucidar o caminho do processo educativo, de forma a tornar possível planejar os métodos adequados para estimular as mudanças responsáveis pela transformação do aluno. "O método ideal será, necessariamente, o que esteja em perfeita conformidade com o objeto que se pretende alcançar" (JOBIM, 1964, p.3). 
No entanto, a definição desse objeto está condicionada também a outros fatores que intervêm nesse processo, desde a visão do aluno, do mercado e da comunidade, até as condições oferecidas pelas escolas para assegurar a aplicação das técnicas mais eficazes para o ensino. É preciso analisar toda a conjuntura didática para poder se estabelecer métodos que efetivamente possam se reverter em benefícios para todos os envolvidos no processo de ensino do jornalismo.

Se a pergunta for feita para profissionais de empresas de comunicação, provavelmente a resposta sobre o que se espera das escolas de jornalismo estará voltada para a preparação de mão-de-obra intelectual qualificada, com conhecimentos das práticas comuns no mercado, que possam atuar nas diferentes áreas jornalísticas. Uma visão que, para Jobim, seria unicamente tecnicista.

\begin{abstract}
Nessa ordem de idéias, a escola serve para "elevar" o nível profissional dos repórteres e redatores, substituindo o ensino nas redações, simples adestramento, por uma iniciação racionalmente orientada por professores. Além das vantagens econômicas, eliminando a fase de "carência profissional" do aprendiz, o sistema proverá aos aspirantes a jornalistas uma visão universal dos problemas da imprensa, e o conhecimento genérico das técnicas fundamentais da profissão. (JOBIM, 1964, p.4)
\end{abstract}

Mas a formação do jornalista deve ser muito mais ampla e abordar o que a sociedade espera desse profissional. É preciso resgatar Rui Barbosa quando explica a importância da imprensa na sociedade: 
A imprensa é a vista da Nação. Vida sem vista é vida no escuro, vida na soledade, vida no medo, morte em vida: o receio de tudo; dependência de todos; rumo à mercê do acaso; a cada passo acidentes, perigos, despenhadeiros. (...) Já lhe não era pouco ser o órgão visual da nação. Mas a imprensa, entre os povos livres, não é só o instrumento da vista, não é unicamente o aparelho do ver, a serventia de um só sentido. Participa, nesses organismos coletivos, de quase todas as funções vitais. (BARBOSA, 2003, p. 37)

Nesse sentido, a importância da preparação universitária está muito mais ligada à formação de profissionais "aptos para melhorar o instrumento de ação social terrivelmente eficaz que é a imprensa", afirma Jobim (1964, p.4-5), sobretudo, preparados e qualificados para suportar as grandes responsabilidades que se atribuem a todos os que usam esse poderoso instrumento.

Mais do que isso, tem a obrigação de formar, educar, descobrir e desenvolver nos alunos tendências e aptidões que, devidamente orientadas, conduz os jovens a uma sólida formação humanística profissional, apoiada em um tripé que considera as questões moral, cultural e técnica durante todo o curso.

O jornalismo, para sobreviver, tem que ter duas condições garantidas, segundo Beltrão (2003, p.157). A primeira é a liberdade, que parte de fora para dentro, e que vai garantir sua competência dentro da sociedade. A segunda, de dentro para fora, é responsabilidade do próprio jornalista, exigida pela sociedade e pelo Estado. 
alcançá-los e de como empregá-los. Em outras palavras, o jornalista precisa - como arauto e pregoeiro das idéias, do pensamento, das reivindicações, dos anseios da opinião pública, enfim - o jornalista precisa de educação especial para a liberdade. (BELTRÃO, 2003, p. 161)

Se não fosse para agir desta forma, não haveria necessidade de nenhuma educação, instrução ou treinamento, insiste Beltrão. Qualquer pessoa poderia assumir o papel de jornalista, como muito aconteceu no passado, sem entender o papel social que acompanha a profissão, mesmo que conhecesse as técnicas jornalísticas. O ensino do jornalismo restrito às técnicas não é capaz de formar adequadamente jovens para o exercício da profissão. A preocupação com a questão da responsabilidade social no jornalismo foi o que moveu, por exemplo, Joseph Pulitzer na criação da Escola de Jornalismo da Universidade de Colúmbia:

\begin{abstract}
Minha esperança é que este colégio de jornalismo levante o nível da profissão. Mas para isso é preciso marcar a distinção entre os verdadeiros jornalistas e os homens que fazem uma espécie de jornalismo que não requer nenhum conhecimento ou convicção, mas um simples treino de negócio. Eu desejo iniciar um movimento que possa erguer o jornalismo ao nível de uma profissão erudita, credora de respeito da comunidade, como outras profissões muito menos importantes têm logrado 0 interesse público. (PULITZER apud JONES, 1947, p. 514 ou BELTRÃO, 2003, p.162)
\end{abstract}

É verdade que no exercício da profissão há muito se deixou para trás a concepção romântica de jornalismo como "espaço de luta ideológica, de denúncia política e de formação de consciência" (STEINBERGER-ELIAS, 1998, p.94). Mas o ensino, como afirma Cunningham (1975, p.16), deve apoiar-se não somente na formação do técnico, mas na formação do homem, entendendo, como Comenius, que a 
educação "é o desenvolvimento integral do homem", ou como Gentile, que acredita ter como função "desenvolver uma visão interior cada vez mais penetrante e aprofundar a consciência da consciência". Essas visões são coroadas por Montaigne, que entende a educação como "a arte de formar homens e não especialistas".

O objetivo do ensino do Jornalismo não pode ser distinto do objetivo geral da educação; deve ser parte do mesmo processo, que Cunningham $(1975$, p.9) resume como sendo o de "crescimento e desenvolvimento pelo qual o indivíduo assimila um corpo de conhecimentos, demarca seus ideais e aprimora suas habilidades no trato dos conhecimentos para a consecução daqueles ideais", resultado que o autor atribui às três transformações que fazem parte do processo educativo: a das capacidades às habilidades, a da ignorância ao conhecimento, e a dos impulsos aos ideais.

Considerando todas essas questões, chegamos ao que Jobim resume como as finalidades de um curso universitário de jornalismo ideal:

a) Formação cultural, ética e profissional do jornalista;

b) Análise e revisão das técnicas jornalísticas através da investigação metódica;

c) Estudo do fenômeno social da informação.

\subsubsection{Formação e Informação}

Mas o que deve fazer parte da formação do jornalista? Para Jobim, não pode haver uma distinção entre matérias formativas ou informativas. "Todas as disciplinas, qualquer que seja sua natureza, devem ter finalidade educativa contribuindo em maior ou menor grau para a formação 
do homem" (1964, p.5). Diferentes áreas do conhecimento, por mais distantes que pareçam do currículo de um curso de jornalismo, têm influência no cotidiano do aluno e despertam sua curiosidade.

A segregação entre cultura e utilidade é a mais importante dentro dos valores educacionais. A distinção não é intrínseca, mas histórica e social. Na Grécia antiga formulou-se que a vida humana era vivida somente pelos que "subsistiam à custa dos resultados do trabalho alheio". A doutrina psicológica das relações entre a inteligência e o desejo ou apetites e entre a teoria e a prática foi decisivamente influenciada por esta circunstância, provocando uma divisão na teoria política entre os seres humanos que são capazes de viver a vida da razão, tendo seus próprios fins, e as pessoas capazes de ter apetites e trabalhar se orientando pelos fins determinados por outras pessoas.

Essas distinções, na pedagogia, refletiram numa separação entre a educação liberal, "que serve a uma vida auto-suficiente de lazeres dedicados ao saber pelo saber, e a preparação utilitária e prática para as ocupações mecânicas, preparação desprovida de conteúdo intelectual e estético" (DEWEY, 1956, p. 324).

Essa separação ainda se mantém até hoje, de acordo com Dewey, mesmo com as mudanças na teoria e na prática, diminuindo a eficácia das medidas educacionais. Por essa razão, o filósofo acredita que acabar com esse dualismo e organizar um curso que torne a reflexão um guia para a atividade prática e dos lazeres a recompensa da aceitação da responsabilidade dos serviços práticos é o grande problema da educação. 
Assim como se contrapõem o trabalho para ganhar a vida e o lazer, também se contrapõem a teoria e a prática, a inteligência e a ação e o saber e o fazer (DEWEY, 1956, p. 325).

Voltando a Platão e Arquimedes, que concordavam em identificar a experiência com interesses puramente práticos, tendo como alvo os interesses materiais e como órgão o corpo humano, o conhecimento existia por si mesmo, sem associação com a prática, e tendo como órgão e fonte um espírito imaterial. A experiência estava relacionada com a falta, a necessidade, o desejo, nunca se bastando em si própria, enquanto o conhecimento racional era completo e compreensivo em si mesmo, interessado na verdade eterna, já que a vida prática era de um fluxo constante.

Esse modo de entendimento era resultado de uma filosofia que se iniciou com a crítica aos costumes e à tradição como "padrões para o conhecimento e a conduta" (DEWEY, 1956, p. 326). A razão era a faculdade com que aprendiam o princípio e a essência universais e os sentidos eram os órgãos que percebiam as mudanças - o instável e o variado em contraste como permanente e o uniforme.

A experiência era associada aos trabalhos manuais e o termo "empírico" não se relacionava com conhecimentos dos princípios, mas com o método de "experiência e erro", com caráter aleatório.

O estudo do jornalismo, no entanto, pode e deve contemplar a observação e a compreensão dos fenômenos sociais, buscando uma 
adaptação dos alunos a uma sociedade em constante mudança. Mudanças que se tornaram cada vez mais velozes, graças ao avanço que Kilpatrick (1978) dividiu em três profundas tendências da sociedade moderna: uma nova atitude mental, diante da vida; a industrialização; a democracia.

Por isso mesmo, a formação do jornalista não deve ser meramente técnica. Conforme Fadul (1979, p.52),

\begin{abstract}
Embora condição necessária, o domínio de uma técnica não é condição suficiente. Essa forma de encarar o ensino nos cursos profissionalizantes manifesta, de forma muito clara, a ideologia da profissionalização, entendida aqui como uma ideologia da permanência do modelo. (...) A única forma desse ensino manter-se atualizado seria transmitir ao aluno uma formação ao mesmo tempo teórica e prática, de forma a permitir, a esse aluno, a sua própria reciclagem frente às novas técnicas revolucionárias.
\end{abstract}

É o que se chama de aprender a aprender. O curso universitário precisa promover no aluno uma mudança capaz de possibilitar que ele, depois de sair da faculdade, busque a atualização constante em sua formação.

Jobim defende ainda que o ensino de jornalismo, em seus múltiplos aspectos, é extremamente adequado para dar ao jovem uma "visão panorâmica das aventuras e conquistas do homem no mundo de nossos dias". E é a escola, como agente da transmissão e distribuição dos conhecimentos intelectuais, que tanto no campo da ciência quanto no da técnica não pode deixar de lançar mão para colocar toda espécie de 
informação a serviço do homem, contribuindo para seu aperfeiçoamento moral.

\begin{abstract}
Em certo sentido, talvez se pudesse dizer que o jornalista é o ser humano melhor ajustado ao seu tempo. Vivendo na aparente vertigem dos acontecimentos, participando deles, mas tendo por ofício o dever de observá-los e interpretá-los, adquire um poder de adaptação excepcional, uma super-plasticidade psíquica. Esta poderá degenerar, com certeza, em leviandade e cinismo. Contra tal ameaça prevalecerá, por certo, a educação integral que ele receberá no meio universitário, onde sua aprendizagem se faça sob o permanente domínio da preocupação ética. (JOBIM, 1964, p.6)
\end{abstract}

É nesse sentido que Jobim vê a interferência fundamental dos professores, mesmo os das áreas técnicas, no sentido de propiciar aos alunos uma visão humanística da profissão, reforçando a responsabilidade social do jornalista, sua relação com o poder e os problemas éticos que terão pela frente. Apenas a inserção da disciplina de Ética não seria suficiente para moldar o aluno dentro de uma conduta adequada a um jornalista. As noções e hábitos que formarão o jornalista, para ele, são assimilados a partir da própria influência da personalidade dos professores e do modo pelo qual ensinam suas matérias, visando mais a educação do que o adestramento profissional.

Essa influência dos problemas enfrentados no cotidiano e das experiências do professor apontadas ao aluno no decorrer do curso representa o que Dewey classificaria de função social da educação (BELTRÁN, 2003, p.50-51), no sentido de entendê-la ligada aos objetivos da própria sociedade. A partir da idéia de que a escola deve constituir um 
ambiente particular no qual possam ser realizadas experiências exemplares da vida social e de que a formação democrática pressupõe o confronto do aluno com determinados conhecimentos específicos, "a vida social na escola terá como base sobretudo o intercâmbio de experiências mediante a comunicação entre os indivíduos, pois a compreensão do mundo que emerge da experiência adquire significado através da linguagem".

Essa responsabilidade jornalística é dividida por Beltrão (2003, p.167) em três aspectos: "para com o indivíduo e a coletividade (jornalismo moral); para com a pátria (jornalismo e nacionalismo) e para com a comunidade internacional (jornalismo e paz mundial)". Entretanto, Jobim defende que a ética jornalística não existe; o que existe é a ética do cidadão, a ética imposta pela sociedade de um determinado tempo.

Com isso, alertava para os perigos da profissão, lembrando Alceu Amoroso Lima (2003), que classificou a facilidade, o sensacionalismo e o mercantilismo como os maiores riscos no exercício da profissão, justamente aqueles que motivam o destaque no aspecto formativo do ensino. Considerando que essa era uma preocupação que não poderia ser perdida de vista no ensino de qualquer profissão, Amoroso Lima destacava que no do jornalismo ela se impunha "pela própria natureza da profissão, assim como por sua passionalidade". 


\subsubsection{Formação profissional}

O ensino universitário, porém, tem outras importantes missões relacionadas ao exercício da profissão: "o descobrimento de caminhos novos; o enriquecimento do acervo de conhecimentos sobre as matérias estudadas; a revisão permanente, por meio da pesquisa, das noções e processos consagrados" (JOBIM, 1964, p.8). O grande desafio da escola, além da formação intelectual, é funcionar como um centro de experimentação, por meio do qual se possa aperfeiçoar as técnicas do mercado.

Para Jobim, a criação do curso de jornalismo no Brasil produziu "uma sensível mudança" no meio profissional, principalmente nas questões técnicas. É preciso entender que, naquele momento, na segunda metade da década de 1940, o modelo norte-americano de jornalismo, que privilegiava o uso do lead, o texto conciso e a pirâmide invertida, ainda não havia sido implantado nas redações. Assim, segundo Jobim, o curso funcionava mais como um curso de aperfeiçoamento do que de formação. Até mesmo porque a maior parte dos alunos era formada por profissionais que já atuavam no mercado e as novas idéias eram introduzidas por eles nas redações. Mesmo com todas as deficiências de um curso em seu início, as críticas às rotinas empregadas e o debate em torno das propostas eram recebidas com entusiasmo.

Mesmo atualmente, cerca de 60 anos após a criação do ensino superior de jornalismo no Brasil, o curso deveria manter a liderança na 
introdução de novas experiências no mercado. No entanto, na maioria dos cursos, o que se percebe é uma corrida em busca de levar para o ensino as práticas que são introduzidas no mercado, todas ditadas pelas constantes mudanças na área tecnológica, que a universidade busca acompanhar adequadamente.

A solução para este problema, então, está na formação adequada do aluno, de modo que ele consiga reciclar e adaptar as técnicas ensinadas às recorrentes mudanças no exercício profissional. 


\section{$5.2 \mathrm{O}$ aluno de jornalismo}

Jobim $(1964$, p.8) defende que conhecer o objeto do ensino não basta para escolher adequadamente quais métodos devem ser empregados no ensino. "Eles dependem, certamente, das peculiaridades de cada disciplina, mas estão subordinados, antes de tudo, à espécie de estudante que vamos ensinar".

Por essa razão, entende que a primeira atenção deveria ser destinada ao processo de seleção de ingresso na instituição que, segundo ele, deveria ser diferenciado, seguindo os mesmos moldes de um processo de escolha de um jornalista para uma redação. Embora o tema fosse, já naquela época, bastante debatido em diversos países, Jobim defendia para o Brasil o modelo implantado, então, na Grã-Bretanha, onde a seleção dos alunos ingressantes era feita pelas próprias empresas jornalísticas.

Considerava também as sugestões apresentadas por Robert Plant, membro do Conselho Nacional para a Formação de Jornalistas e funcionário da União Nacional dos Jornalistas Britânicos, para quem o primeiro fundamento de seleção seria o controle numérico das matrículas, de modo a assegurar que a oferta de profissionais graduados correspondesse à demanda. Essa limitação, embora compreendida como benéfica, era vista como impossível de ser adaptada a países como o Brasil, onde o ensino nas universidades estava distante do mercado de 
trabalho e onde a tendência - agora confirmada - de proliferação de cursos de jornalismo tornava-a inviável. Além disso, ainda havia a questão de a limitação de ingresso ser entendida não como uma necessidade das empresas, mas como um processo de seleção que assegurasse a "eficácia do ensino".

A segunda questão levantada por Plant dizia respeito a proporcionar, dentro de uma seleção, oportunidades iguais para todos os jovens que pretendessem seguir a carreira de jornalista, condição referendada por Jobim.

O terceiro questionamento referia-se à escolha do pretendente, propriamente dita, que recairia no aluno que correspondesse ao modelo procurado pelos veículos de comunicação. Embora Jobim concordasse que a seleção devesse contemplar o interesse do mercado, acreditava que a falta de contato entre escola/imprensa impedia as universidades de compreender quais eram as reais necessidades do mercado. Para isso, defendia uma aproximação entre as duas instituições, que pudesse levantar problemas comuns.

O último ponto levantado por Plant era uma seleção que levasse em consideração a formação moral e intelectual do candidato, correspondendo "às exigências do bem comum, levando em conta o importante papel desempenhado pela imprensa na sociedade". Mas que meios utilizar para descobrir essas aptidões nos candidatos, geralmente jovens saídos do ensino médio? 
Tudo isso são conjecturas, porque os regulamentos de seleção são determinados pelas instituições de ensino e o professor entra em sala de aula com os candidatos já selecionados. A partir daí, como agir diante de seus alunos?

\begin{abstract}
O primeiro cuidado do professor - sabem todos - deve ser procurar conhecer a seus alunos. Ao se iniciar o curso, costumamos solicitar ao principiante um trabalho sobre as razões por quais se decidiu pelo jornalismo e não por qualquer outro curso. Em seguida, fará o aluno uma concisa autobiografia, que servirá de fundamento para uma conversa com o professor. Por fim, dirá, por escrito, quais são os jornais e revistas que lê, assim como por que os lê. (JOBIM, 1964, p.11)
\end{abstract}

Essa sugestão de Jobim parece óbvia. No entanto, trazida para a realidade atual das escolas de jornalismo, contempla apenas um pequeno grupo de instituições onde as turmas são formadas por um grupo mais selecionado de alunos e a aproximação do docente fica mais fácil. A realidade nacional, de turmas formadas com 80,100 ou mais alunos, impede uma aproximação e acompanhamento cuidadoso dos alunos.

Jobim, entretanto, acredita que se o professor não pode intervir no processo de seleção, deve procurar a melhor forma de conhecer os alunos. Ele dizia ter encontrado três diferentes classes de alunos no seu convívio universitário: os que pretendem exercer a profissão, os que já exercem e querem se especializar e os que fazem um curso universitário apenas para ter um diploma de nível superior. Atualmente, é possível se encontrar mais duas diferentes classes: os que ainda têm dúvidas com 
relação à profissão que querem exercer, por terem ingressado muito jovens no curso e pelo excesso de exposição às informações, e, a mais danosa, os que vêem no jornalismo apenas um trampolim para obter fama e sucesso, estes muito mais influenciados pelo fenômeno da televisão. Não raro se encontra alunos que enxergam a possibilidade de, por meio do jornalismo, se tornar astros ou estrelas de televisão, pouco entendendo do que deveria ser o real sentido ou missão da profissão.

Por isso, a sugestão de Jobim (1964, p.11) de conhecer melhor os alunos, seja para perceber "as modalidades de incentivo que pedem o temperamento de cada um; seja para fazer com que não desperdicem seu tempo, prosseguindo no curso, quando Ihes faltam condições para o êxito relativo nos estudos". Mesmo porque é possível encontrar, segundo ele, até entre aqueles que querem apenas diplomar-se, talentos ou excelentes alunos, assim como é possível encontrar jornalistas medíocres entre aqueles que já exercem a profissão.

O conhecimento mais pessoal possível de cada aluno possibilita, com certeza, ao professor de jornalismo reconhecer no aluno as características necessárias para servir à sua formação jornalística. Essas características são certos atributos psicológicos e intelectuais que marcam o que se convém chamar de "vocação" para o jornalismo.

É claro que esses atributos não são avaliados no ingresso na escola superior, tampouco nos antecedentes do curso secundário. Os primeiros contatos com um aluno também são ineficazes para uma análise 
adequada de sua vocação, mas servirá, ao menos, para sugerir que este ou aquele tem "suas possibilidades".

Jobim considera que o fato de alguém escolher o curso por querer tornar-se jornalista - e não por desejar um diploma - já "é a mais valiosa indicação de que esse alguém pode se converter num autêntico jornalista". Mas, como ele mesmo admite, "apenas uma indicação", em razão do "glamour" que rondou, e ainda ronda, a profissão.

Também há a possibilidade de o professor se deparar em classe com alunos que escolheram o curso por considerarem o jornalismo como "aparentemente fácil". De toda forma, é fundamental que o professor estimule mesmo os casos mais difíceis, principalmente em razão da complexidade de causas que motivam a escolha de um curso e de uma profissão. Não é de todo impossível que um estudante medíocre possa se transformar, ao final do curso, em um bom aluno ou bom profissional.

Mas essas são discussões que permeiam o campo das suposições. De concreto tem-se unicamente o fato de que o maior ou menor êxito dos estudantes reside nos meios empregados para conquistar sua espontânea adesão ao plano de estudos e nos estímulos que lhes são proporcionados para que "assumam livremente a responsabilidade de executar as tarefas de aprendizagem" (JOBIM, 1964, p. 14). E embora essa seja uma questão que concerne ao método, que trataremos mais à frente, desde já é importante deixar claro que a motivação do aluno é responsável pelo seu sucesso. E que a escola e o professor são as peças fundamentais desse 
processo, estimulando suas habilidades. Isto porque, de acordo com Dewey (1956, p.339):

\begin{abstract}
A função da escola não é transportar os adolescentes de um ambiente ativo para outro de um estudo inerte dos registros daquilo que os outros homens aprenderam, e sim levá-los de um ambiente de atividades relativamente casuais (casuais em relação à compreensão e à inteligência que possam proporcionar) para outro de atividades selecionadas, tendo em vista servir de guias para o aprendizado.
\end{abstract}

Sem dúvida, o aluno convenientemente preparado pode desenvolver suas competências. Para Jobim (1964), é preciso encontrar no jovem estudante as quatro qualidades que considera básicas no jornalismo: "curiosidade para perseguir o acontecimento; imaginação para descobrir nas coisas o ângulo novo e atual; objetividade para vê-las sem distorções; e comunicabilidade para narrar o que viu". Esses são atributos da personalidade do jovem que demonstraram sua "disposição de espírito" para a profissão, embora seja preciso somar a essa disposição os métodos que serão proporcionados pelo professor.

Mas as causas do êxito ou do fracasso dos estudantes são bem mais complexas e classificar alunos em grupos, a fim de adaptar os métodos de ensino às suas peculiaridades, é muito mais difícil do que parece. Nessa questão, os alunos de jornalismo não são diferentes dos alunos de qualquer outro curso e os professores passarão pelas mesmas situações de adaptação de seus colegas de diferentes áreas. 
Um dos pontos relacionados ao sucesso do aluno vai além de sua vocação ou de suas habilidades: é a questão da maturidade. Como dissemos, muitos saem do curso secundário sem ter noção do que querem fazer. Embora, em sua maioria, adolescentes, passam a ser tratados como adultos no curso universitário, muitas vezes sem estarem preparados para tal. É importante ressaltar que o adolescente tem exigências psicológicas que são peculiares das crianças. Muitos, com certeza, não tem a mesma capacidade de abstração de um adulto e encontram dificuldades de passar horas em sala de aula compreendendo as lições e participando de atividades.

\begin{abstract}
Partindo da premissa de que essa capacidade de abstração é forte nos adultos - sem levar em conta a enorme desigualdade que existe entre uns e outros a esse respeito - renomados pedagogos sustentam que o que importa no ensino superior é ditar a matéria. Importa pouco a forma como se faça. O bom professor seria aquele que "esgota a matéria". Os estudantes que já alcançaram uma espécie de emancipação pedagógica seriam pessoas responsáveis, sedentas do saber do mestre, desejosas de ler os livros da bibliografia por ele recomendada, ansiosas por assimilar conhecimentos que Ihes permita chegar com bom êxito ao fim do curso e encontrar lá fora a recompensa a seus esforços. (JOBIM, 1964, p. 51)
\end{abstract}

É importante lembrar que o ser humano vai ser transformando na medida em que passam os anos, no sentido de que evolui. Isso ocorre em razão de seu contato com o mundo exterior e das mudanças filosóficas que correspondem a mudanças psicológicas. "A assimilação de novas e sucessivas experiências contribui para alterar o temperamento, o caráter, os gostos e as preferências; vale dizer, o comportamento de cada homem", lembra Jobim. 
Por isso, o valor da experimentação na pedagogia, que Raymond Buyse (1959), em “Experimentacion en Pedagogia”, insiste em apontar:

\begin{abstract}
A experimentação é incontestavelmente mais difícil na pedagogia que em outra ciência qualquer; mas, por ela mesma, nunca foi em nenhuma mais necessária nem mais indispensável. E, com certeza, quanto mais complexa é uma ciência, mais necessário será estabelecer uma boa crítica experimental, a fim de obter feitos comparáveis e isentos de causas de erros.
\end{abstract}

O desenvolvimento do homem atravessa fases distintas onde cada uma delas é uma unidade funcional cujas capacidades de reação se ajustam às necessidades específicas dessa fase. Por isso, a estrutura psicológica e mental de uma criança não permite que ela perceba seguramente tudo o que um adulto percebe.

Mas tanto o adulto como a criança não atuam sem um interesse, sem um objetivo. Existe uma identidade entre eles, do ponto de vista funcional, conforme aponta Clarapède (1940), que faz com que a necessidade, embora diferenciada na estrutura, seja a responsável pela ação. Assim, há "distinção de estrutura e há identidade funcional; distinção de meios, mas comunidade de fins". Essa distinção é explicada pelo autor com o caso da respiração no girino e na rã. Embora ela tenha a mesma finalidade em ambos, os meios de que se servem para respirar - em um caso os pulmões e no outro as brânquias - são distintos. 


\subsection{O professor de jornalismo}

Danton Jobim dizia que não era professor. Assim como todos os demais professores de jornalismo, ele era jornalista. E teve que, antes de ensinar, aprender. Foi dessa forma que ele iniciou o que chamou de sua "aventura didática", descobrindo, inicialmente, como se aprende a ensinar. Primeiro, através da observação empírica. Depois, sistematizando as informações adquiridas por meio das leituras sobre o assunto no que chamava de fichário. Chegou a dizer que o seu curso de pedagogia para o jornalismo poderia ter como subtítulo "Notas do meu fichário", ressaltando que o que fazia eram "simples apontamentos de um fichário rigorosamente organizado por um jornalista-professor", que se convertiam em exposições coerentes sobre os dados recolhidos da experiência e reminiscência de leituras.

Mas o papel do professor universitário, mesmo sendo um profissional antes de um professor, não pode ser entendido nesse molde simplista. Isso porque a primeira questão aqui a ser levada em conta é que a "efetivação de qualquer política educacional é realizada, em última instância, na sala de aula e os seus principais agentes são os professores" (REALI; TANCREDI, 2001, p.159), sendo deles, portanto, o papel de destaque na determinação e implantação de políticas educacionais.

Cabendo a ele essa função, questionamos qual seria o professor responsável pela aplicação de um método mais adequado, com melhores 
recursos e formas de motivação do aluno num curso de jornalismo? "O jornalista", defende, sem qualquer sombra de dúvida, Danton Jobim.

Quanto às disciplinas técnicas, não há dúvida de que só podem ser ministradas por jornalistas. E quanto aos professores das demais disciplinas? "Todos devem ter tido algum contato com os problemas da imprensa", insiste Jobim (1964, p.15), condição que entende ser necessária para que os mestres, mais do que conhecer as necessidades da profissão, "saibam dar prioridade no ensino de suas disciplinas ao que verdadeiramente interesse na formação do jornalista completo". Este ponto é o primeiro que Jobim levanta em sua proposta pedagógica: o professor deve, preferencialmente, ter experiência jornalística, independentemente da disciplina que lecione.

É bem verdade que isso seria mais fácil no período anterior à regulamentação profissional de 1969, que passou a exigir o diploma de jornalismo. Atualmente, é mais raro - embora não impossível - encontrar jornalistas com dupla formação voltados para ministrar aulas nas variadas disciplinas que constam dos currículos. Mas, mesmo nesse caso, seria importante que o professor conhecesse o máximo possível sobre a prática jornalística para que pudesse selecionar os temas mais importantes para os estudantes da área.

Como já dissemos anteriormente, são os estímulos proporcionados pelo professor os responsáveis pela motivação do aluno. No caso de um professor-jornalista, o estabelecimento de nexos entre o conteúdo teórico das disciplinas e o exercício profissional será muito mais constante, 
possibilitando a aplicação de "maiores recursos para incitar a classe por meio de estímulos adequados". A própria atividade jornalística possibilitará que sua atuação como professor seja muito mais prática, dando condições de se levar para a sala de aula as ocorrências e curiosidades do dia-a-dia, "artifício útil para criar um ambiente favorável e despertar o interesse dos alunos".

A eficiência do trabalho do mestre é mais importante ainda quando faltam as condições que poderiam enriquecer o curso, por meio de trabalhos práticos. $\mathrm{Na}$ ausência de equipamentos adequados laboratórios, veículos experimentais, entre outros - é que a prática diária do professor nas atividades jornalísticas vai enriquecer o ensino. É evidente que a falta desses equipamentos traz transtornos para o desenvolvimento do programa das disciplinas. Mas os métodos de ensino devem ser adaptados às possibilidades da escola. É na ausência de condições adequadas que o professor mostra suas habilidades, fazendo o melhor "possível" com os instrumentos de que dispõe e inovando os meios, de modo a impedir a inatividade do aluno.

A vivência na profissão propicia ao professor mais facilidade para inspirar seus alunos, num primeiro momento, e motivá-los durante o desenvolvimento do curso. O professor deve ser, acima de tudo, um modelo que o estudante procurará seguir, a imagem do profissional que querem ser, o ideal que pretendem atingir.

Não é incomum que se encontre atualmente, nos quadros docentes de instituições, professores que se queixam da profissão, desestimulam o 
aluno, reclamam do mercado de trabalho, entre outras tantas coisas. Como esperar que esses mestres sejam os responsáveis pelos estímulos que devem ser propiciados aos alunos. O professor de jornalismo deve ser um jornalista autêntico, que compreenda e ame sua profissão, que ilustre suas aulas com suas experiências e, como acredita Jobim, "comente apaixonadamente os problemas do jornalismo, sem decair, contudo, no fanatismo e nas tramas da política".

Para ele, este é o quadro ideal, mesmo considerando difícil de ser encontrado. E que, sem dúvida, reforça a importância do professor como guia didático estimulador do fator afetivo, que faz parte da distinção triangular ${ }^{10}$ das funções mentais, ao lado da cognição (conhecimento) e da conação (ação) (CUNNINGHAM, 1975, p.66). A aprendizagem é estimulada por motivos morais ou sentimentais. E muitos dos que buscam a escola de jornalismo o fazem porque têm propósitos mais altos, que vão além do fim utilitário de obter um emprego ao terminar os estudos.

É importante frisar que a motivação, sob o ponto de vista da psicologia educacional, é entendida, tanto na teoria quanto na prática, não como pequenas receitas a que o professor recorre para "tornar menos aborrecida suas lições", mas como um instrumento voltado em direção de todo o processo educativo (LOURENÇO FILHO, 1978, p. 78). A tarefa do professor não é modelar uma massa inerte, como a do escultor, mas despertar no aluno o interesse, considerado por muitos educadores como

\footnotetext{
${ }^{10}$ As outras distinções das funções mentais são: a horizontal (vida racional - intelecto, emoção e volição - e vida sensorial - sensação, impulso e sentimento) e a vertical (cognição - sentidos e intelecto - e apetição - impulso e vontade).
} 
a chave da aprendizagem. Os interesses variados do homem são os que os diferenciam dos animais, que vivem segundo os apetites do corpo.

Dewey (apud CUNNINGHAM, 1975, p. 121) vai além, afirmando que o interesse vem com a instituição de problemas. "O pensamento começa no que, com justeza, podemos chamar de ponto de bifurcação, ponto ambíguo, que formula um dilema, que propõe alternativas..... Os problemas diários são estimulantes para que se busquem soluções. É através da necessidade de buscar respostas a eles que a reflexão se desenvolve; no sentido de resolver problemas.

Mas uma boa dose de idealismo trazida pelo aluno é um excelente motivador da aprendizagem. Jobim, para justificar que não se pode destruir no aluno a visão nobre do jornalismo, lembra Walter Lippman (apud JOBIM, 1964, p.56): "a imprensa é posta, segundo a imaginação popular, ao nível de instituições como a Universidade e a Igreja”. Para ele, é preciso que o professor valorize realisticamente a função da imprensa, com o cuidado de não destruir essa visão, sobretudo no primeiro ano, "período de adaptação do estudante ao ambiente acadêmico e à especialização da própria universidade". Sem dúvida, alguns fatores afetivos influenciam profundamente o jovem ingressante no ensino superior. Entre eles, além do próprio ambiente da escola, estão a personalidade do professor-jornalista e a admiração pelos colegas que já exercem a profissão.

O próprio ensino da história do jornalismo já funciona como elemento motivador. Por isso, os professores de todas as disciplinas do 
curso devem conhecer os feitos importantes, sugestivos e pitorescos da história da profissão, "para recorrer a eles nos momentos oportunos com fins motivadores".

Se é reconhecido que o sentimento é um fator de aprendizagem, nada mais adequado do que o professor reconhecer a importância de seu ofício - como jornalista -, o orgulho profissional com que exerce sua profissão, sua satisfação e paixão pelo que faz. Isso faz bem para o estudante, da mesma forma que na obra do artista realiza-se a síntese técnica-sentimento, que chega ao estado de perfeição na obra mestre, representada pelo domínio da técnica após anos de estudo, o que só é obtido plenamente quando é posto o amor na aprendizagem.

\subsection{O currículo}

Para tratar da questão do currículo no curso de jornalismo, Danton Jobim (1964, p.52) faz uma analogia entre matéria no jornal e matéria na escola. Assim, ele explica, "o material, nas redações, é o assunto. A matéria, no jornalismo, não é tudo, porque necessita ser transformada pela mente do jornalista até chegar a ser jornalismo". Os repórteres reagem diante de um conjunto de fatos que constituem a notícia que eles devem elaborar. Da mesma forma, as matérias que compõem o currículo escolar devem ser uma combinação de temas que possam instigar a mente do aluno, provocando reações às questões propostas, "seja buscando 
solucioná-las, seja esforçando-se para compreender seu significado, o que já é começar a resolvê-las".

Ensinar suscitando problemas cria no aluno a disposição e a capacidade para formulá-los e resolvê-los por seu próprio esforço. É uma forma de ajudar o aluno a buscar por si mesmo as respostas às questões apresentadas, explorando os temas em busca de seu significado. Essa capacitação do estudante é o que vai ajudá-lo a assimilar as experiências ao longo da vida, de forma que elas contribuam para enriquecê-lo cada vez mais.

Mas isso levanta uma questão fundamental na pedagogia: o que ensinar? O currículo de um curso está afinado com o seu próprio objetivo e finalidade. Se nos propomos a formar jornalistas, devemos ensinar jornalismo.

Porém, a questão não é tão simples. Jobim refere-se à formação de jornalistas, em primeiro lugar, e, em segundo, à formação eventual de especialistas em investigação sobre informação e opinião pública como finalidades do curso. E embora ele enfatize o caráter profissional do curso, adverte que isso não significa relegar a um plano secundário as disciplinas de caráter cultural.

Isto sequer seria possível. Como formar jornalistas sem os conhecimentos culturais necessários para a compreensão do mundo? Pelo contrário, Jobim (1964) defende que o aprendizado deve buscar "formar na mente do estudante os valores utilitários, culturais e disciplinares que se tornam 
necessários para a atividade jornalística". Ele atribui à escola a responsabilidade da informação, com o cultivo e com a disciplina da mente do estudante, sendo: a informação relacionada à profissão e seus problemas, o cultivo da mente associado às atitudes correspondentes aos ideais da vida jornalística, e a disciplina como forma de reforçar no aluno as condições para que ele adquira as habilidades relacionadas com as técnicas profissionais.

Essas seriam as condições para se criar um modelo adequado de jornalista, considerando a importância da imprensa dentro da sociedade moderna. O ensino do jornalismo seria um conjunto global de informações que pudesse formar jovens qualificados para representar esse ideal de imprensa concebido na mente das pessoas.

Essa questão já responde o porquê da necessidade de não se ensinar apenas as técnicas jornalísticas. Com pretender que o aluno tenha uma visão de mundo aprendendo como se faz um lead? O jornalismo não é apenas um conjunto de técnicas e habilidades aplicadas a um fim puramente pragmático.

Da mesma forma que em outros cursos, a aprendizagem não pode estar associada unicamente a um aspecto técnico. Seria o mesmo, compara Jobim, de se formar um cirurgião a partir do ensino unicamente da Prática Cirúrgica. O médico emprega mais que seus conhecimentos técnicos para abrir um abdômen de um paciente. "Em toda sua visão do campo científico da profissão, toda sua personalidade enriquecida por uma série orgânica de conhecimentos adquiridos na universidade, toda sua 
consciência profissional formada e amadurecida com o contato com os mestres; é tudo isso que o capacita para exercer de modo cabal e responsável seu ofício de médico ou de cirurgião". Mesmo a partir de disciplinas que talvez nunca sejam utilizadas na vida profissional, o fato de ter tido contato com elas favorece uma mente aberta para novos conhecimentos e novas descobertas.

\subsubsection{O que se ensina na escola de jornalismo}

O que pretendemos demonstrar é que, a partir da visão de Danton Jobim, tudo que se ensina em uma escola de jornalismo é jornalismo. Do currículo faz parte uma série de conhecimentos necessários para a formação do jornalista. Dessa forma, Jobim considera que a "matéria jornalismo" é igual a Literatura mais História, mais Geografia, mais Sociologia, mais Economia e outros ramos do conhecimento humano, somadas à disciplinas características, como Legislação e Administração, às quais se somam as técnicas jornalísticas especializadas. Qualquer matéria que adicione conhecimentos necessários para a formação de um jornalista deve fazer parte do currículo, da mesma forma que as que não tenham utilidade devem ser excluídas.

No entanto, não é tão simples perceber o que é útil e o que é inútil na organização de um currículo. Nesse sentido, Celso Cunha11,

\footnotetext{
${ }^{11}$ In: Jornalismo e Universidade, MEC, Rio de Janeiro, apud Jobim, 1964.
} 
catedrático de Português e Literatura da Faculdade Nacional de Filosofia, lembrava:

\begin{abstract}
Inegável a importância da aprendizagem metódica e especializada [de jornalismo]. Não é fácil, não obstante, fixar um currículo das disciplinas necessárias para a formação profissional do jornalista. Em outros cursos o problema não se reveste da mesma complexidade (...) ao jornalista, em certo sentido, tudo o interessa.
\end{abstract}

Por certo, esse era o motivo de no relatório apresentado no Seminário do Ciespal ocorrido em Quito, em 1958, se encontrar uma tão grande diversidade de currículos na América Latina nos cursos de jornalismo. Naquele momento, o professor Héctor Mujica, da Venezuela, apontava existir o que ele chamava de "autêntica anarquia", considerando haver uma tendência humanística e teorizante, em detrimento da capacitação técnica.

É verdade que essa era uma situação muito presente naquele momento, principalmente considerando-se a falta de laboratórios e adestramento profissional adequados. Havia também a questão do despreparo dos professores de jornalismo, que até então não buscavam qualificação adequada para ministrar aulas. As instituições universitárias não conseguiam dar aos alunos o treinamento prático necessário por falta de equipamentos didáticos apropriados, o que transformava o currículo num amontoado de disciplinas teóricas. É evidente que as reclamações consideravam muito mais essa questão do que praticamente a formação humanística oferecida. Mas é bom lembrar que sempre é mais fácil 
assimilar as técnicas profissionais do que formar uma cultura geral, conforme insistia Jobim, considerando inclusive que a diversidade dos currículos é muitas vezes útil e necessária, já que possibilita o ajustamento à realidade de cada região - caso inclusive do Brasil, que tem vasta área geográfica e muita diversidade regional.

\subsubsection{As humanidades no curso de Jornalismo}

A importância do ensino das humanidades no curso de jornalismo está associada à formação de uma cultura geral. "É mais fácil fazer um bom jornalista de uma pessoa culta, que nunca entrou numa redação, que de outra que, conhecendo os segredos ou truques do ofício, não possui um nível razoável de cultura geral”, assegurava Jobim, que já tinha vivenciado na redação do Diário Carioca a experiência de formar jornalistas.

Defendia, inclusive, que as disciplinas culturais não poderiam ter um papel de segundo plano na formação do aluno, considerando que elas eram uma "porta aberta ao trato inteligente dos problemas mais diversos".

Mas, como em sua visão tudo o que é ensinado no curso faz parte da grande disciplina "jornalismo", a questão que se coloca é como mesclar as disciplinas humanísticas com as técnicas da profissão dando um formato de unidade? A mesma pergunta foi levantada no "Seminário sobre a Formação de Jornalistas", ocorrido no Rio de Janeiro, em 1958, quando 
se sugeriu que as escolas buscassem a coordenação dos elementos culturais e técnicos. Recomendou-se que, na parte humanística, fosse dada preferência ao ensino formativo, com maior destaque às disciplinas que "ensinam a pensar e a ordenar as idéias, a conhecer e penetrar na realidade nacional e internacional, a interpretar o sentir coletivo e a consolidar as normas morais que regem o exercício da profissão".

Jobim exemplifica essa proposta com a disciplina História da Civilização. O enfoque a ser dado nessa matéria, diz ele, deve priorizar preferencialmente épocas e aspectos da evolução humana que estão mais ligadas às necessidades da profissão. Embora não existam diferentes histórias da civilização para uma ou outra profissão, existe a necessidade de o jornalista conhecer determinados aspectos da história da humanidade, possibilitando, a partir disso, que ele interprete melhor e sem distorções o seu próprio tempo. Desta forma, justifica, capacita-se o jornalista para escrever, por exemplo, crônicas, que faz parte do seu ofício.

A verdade é que sem os fundamentos de uma cultura bem diversificada, a escola fracassa em sua missão, que é, acima de tudo, a educação para o jornalismo. O caso da História ilustra muito bem essa relação cultura e jornalismo.

Em "The use of History", A.L. Rowse acentua que, talvez, não por simples coincidência, alguns dos mais vigorosos comentaristas da imprensa de Londres, "homens que desempenham grande papel na formação de uma inteligente opinião pública em assuntos internacionais" - como o editorialista internacional do "Times"; "Candidus" do Daily Sketch; "Scrutator" do Sunday Times - são mentalidades embrenhadas historicamente; dois deles são, por direito próprio, 
distinguidos historiadores e "Candidus" alimenta uma paixão devota pela matéria". (JOBIM, 1964, p. 63-64)

Embora seja uma disciplina oferecida no curso secundário, no curso superior a História passa por um aperfeiçoamento, buscando elevar o nível de conhecimento do estudante. É bem verdade que não se pretende formar historiadores, mas sua contribuição à cultura geral é fundamental na formação de um jornalista, até para que ele possa entender, a partir do passado, a realidade de seu tempo, associando conhecimentos.

Jobim insiste que não há secretário de redação que não tenha constatado que é mais fácil fazer um bom jornalista de uma pessoa culta que desconhece todas as técnicas e truques da profissão do que de alguém que, mesmo com experiência jornalística, tenha um baixo grau de instrução geral. Existem exceções, sem dúvida, de jornalistas ou proprietários de jornais que, no passado, conseguiram destaque mesmo com uma formação deficiente, mas elas fogem à regra geral. A história da imprensa mostra casos como esses quando o nível superior ainda não era exigido. Mesmo assim, continuam sendo exceções, principalmente se considerarmos o mercado de trabalho atual, cada mais exigente e seletivo.

A realidade do jornalista atualmente é outra. É verdade que muitos jovens, mesmo com a graduação concluída, possuem um grau de conhecimento geral que deixa muito a desejar. Os que se sobressaem, no entanto, são aqueles que, a partir de uma forte cultura geral interpretam os 
acontecimentos, acrescendo de qualidades os seus textos e informações.

Ou como disse Susanne Marie Durant (apud JOBIM, 1964, p. 68):

\begin{abstract}
O estudo das letras (melhor seria dizer das "humanidades") abre ao espírito o caminho da verdade, porquanto o leva, ao menos, à dúvida e à crítica, garantia preciosa contra o erro e pára-raios contra a propaganda. Aguça também o espírito de sutileza, o sentido das gradações, a penetração psicológica, dons mais preciosos para o conhecimento do homem, que nossas experiências de laboratório, onde o psiquismo parece dissecado pelo bisturi.
\end{abstract}

Essa capacidade de interpretação e crítica, se já é importante em todas as profissões, torna-se essencial para o profissional que tem por obrigação informar. A variedade de contradições que se encontra nas diferentes opiniões e pontos de vista necessita alguém com uma qualificação diferenciada, capaz de levar ao público "a imagem tão fiel como humanamente possível, da complexa e dinâmica realidade". Profissionais que possam escolher e relacionar fatos, descrevendo e interpretando, e, finalmente, apresentando à sociedade uma visão equilibrada dos acontecimentos.

Esse é um profissional que já nasce pronto, diriam alguns, que ainda insistem em queixar-se da obrigatoriedade do diploma de jornalismo. Muitos nascem, é verdade, com uma inteligência mais acentuada e com a característica da curiosidade. Mas é, sem dúvida, a partir do interesse pela educação que essas qualidades se acentuam ou não. É possível adquirir conhecimentos e habilidades necessários para a prática do jornalismo (e 
de outras profissões, é claro) através do estudo e da valorização do conhecimento que organiza a concatenação de fatos.

Converter os fatos em notícias, narrá-los, descrevê-los, comentálos, interpretá-los, é aí que se mostram necessários os atributos tipicamente literários que estão ligados a uma rede de conhecimentos de que o jornalista não pode escapar. Aí está o elo com a formação humanística essencial para o desenvolvimento da profissão. É o caso do jornalismo francês, inferior ao norte-americano em técnicas, segundo Jobim, mas que conserva "a primazia na excelência do relato, ou seja, na apresentação literária, ainda que do 'fait-divers' ${ }^{12}$, quando merecido pela sua relevância".

Mas mesmo a simples notícia pede a capacidade de síntese, de recompor a realidade fragmentada do cotidiano, de forma que o leitor possa assimilar a informação. Esta qualidade não pode ser encontrada no jornalista sem preparo, em razão da necessidade de integrar os fatos, discernir o que é fundamental nos dados captados pelo repórter. A falta de cultura se traduz no jornalismo pela insegurança no texto. A cultura, ao contrário, leva-o em busca de novas investigações, novas revelações, que assegurarão um texto preciso. É essa ânsia pela aventura intelectual, a curiosidade frente ao desconhecido que faz surgir um grande repórter.

\footnotetext{
12 "Fait-divers" significa fatos diversos, geralmente associados a escândalos, curiosidades e bizarrices; é sinônimo de imprensa popular e sensacionalista, embora esteja cada vez mais presente nos veículos tradicionais, principalmente na televisão. De acordo com Annik Dubied e Marc Lits (Les Fait Divers. Paris, PUF, 1999), é uma "representação do extraordinário ordinário", uma espécie de pequena história do cotidiano, sem grande alcance, num espaço global menor e mais próximo da vida das pessoas. Com origem nas histórias orais do século XVI, associado a crimes, delitos e catástrofes, entre outros, surgiu na imprensa popular no século XIX.
} 
Jobim (1964, p. 70-71) traça alguns paralelos:

\begin{abstract}
Ninguém poderá confundir, é certo, o ensaio de um filósofo com o artigo de um jornalista. Mas nos artigos de um Raymond Aron ou de um Walter Lippman, grandes expressões do jornalismo francês e norte-americano, não estarão porventura condensadas toda sua vasta cultura humanística e sua coroação, a cultura filosófica? (...) Lippman ou Aron não se fizeram bons jornalistas porque adquiriram as habilidades técnicas, o know-how do jornalismo. Isto foi um aditamento a sua ampla cultura geral, por simples acessão. São casos em que a maturidade intelectual, conferida por uma excelente formação de tipo humanístico, elimina as dificuldades do "metier" e propicia a rápida apreensão dos procedimentos técnicos ou profissionais.
\end{abstract}

\title{
5.4.3 O ensino da Geografia e da História na Escola de Jornalismo
}

A grande vantagem do homem sobre os animais é aprender e descobrir o significado das coisas. É essa significação que indica a distância entre a civilização e a selvageria (DEWEY, 1936). O caminho mais fácil para atingir e reter esse conhecimento é através do aprendizado das experiências vivenciadas, fundidas com aquilo que foi ensinado ou informado por outro. E essas experiências dizem respeito à relação do homem com a natureza.

É nesse sentido que a Geografia e a História contribuem para o conhecimento, por serem por excelência disciplinas informativas. É a análise de seus materiais e seus métodos que farão a diferença entre a mera acumulação de informações isoladas e a penetração dessas informações na experiência viva do homem. Por essa razão, são matérias, 
segundo Jobim, imprescindíveis em um currículo universitário de jornalismo. “Poucas apresentam cunho tão eminentemente 'enciclopédico' e se ajustam tão bem a um plano de estudos que leve à conquista da cultura geral".

Estudar Geografia, diz Dewey, é aumentar a faculdade de perceber as relações espaciais, naturais, de um ato ordinário, enquanto estudar História é a forma de assegurar o aumento da capacidade de reconhecer as relações humanas do mesmo ato. Geografia e História proporcionam a dupla dimensão do que se passa na superfície da terra: tempo e espaço.

\section{O ensino da Geografia para jornalistas}

Se a História preserva a obra do homem, a Geografia explica o que se passa na superfície do planeta. Para o homem, tudo na Geografia deve interessar, já que está relacionado às atividades do homem sobre a terra, num esforço milenar de dominar o meio geográfico.

São diversos os aspectos da Geografia que devem ser ensinados (geografia física, matemática, astronômica etc.), mas, segundo Jobim, é a geografia biológica ou biogeografia a que mais diretamente interessa na formação do jornalista, embora reconheça que não devemos nos enganar pelas divisões da ciência. Tudo o que se passa na superfície do planeta, em função das atividades que nele se desenvolve, deve ser de interesse 
porque, no mundo das preocupações científicas tudo começa e tudo termina no homem.

A Geografia é ponto de convergência de muitas ciências e, por isso, pode ser considerada como uma ciência "enciclopédica", por causa dos conhecimentos ecléticos que exige e da enormidade de seu campo. Seus benefícios, de acordo com Demangeon (apud JOBIM, 1964), são suas condições de localizar, descrever e comparar, explicando os fatores dos meios em relação com o homem.

Jobim acrescenta que, assim como a Geografia, o jornalismo também localiza, o jornalismo descreve e o jornalismo compara. "Antes de ser notícia, o fenômeno é geografia. Sua importância para o jornalismo está relacionada com sua localização, isto é, com o meio que a condicionou".

É através do seu ensino que o estudante poderá ter uma ampla compreensão dos problemas sociais, econômicos e políticos do mundo, através do conhecimento sobre a distribuição dos povos e raças no planeta, dos diferentes recursos econômicos, da circulação da riqueza, tudo isso em níveis regionais, nacionais e mundiais.

$\mathrm{Na}$ verdade, como escrever sobre conflitos ou economias distantes geograficamente sem conhecimento da geografia humana. É através da comparação que se é capaz de atingir o conhecimento sobre as coisas e se pode explicar o significado dos fatos. 
Cada um dos acontecimentos está, sem dúvida, integrado ao meio geográfico, por isso, a capacidade de compreensão dos fatos está associada ao conhecimento geográfico do jornalista. É inconcebível um jornalista que desconheça o que se passa no mundo. Se isso já era uma realidade no século passado, quando as duas grandes guerras mundiais invadiam as páginas dos jornais, que dirá num mundo globalizado como o de hoje, quando informações sobre os acontecimentos dos países do outro lado do planeta estão disponíveis na internet ao mesmo tempo em que os acontecimentos do nosso bairro. É o conhecimento de geografia que dará maiores oportunidades ao jornalista de informar com qualidade e interpretar com qualidade os fatos. E essa é a forma de o jornalismo contribuir para o progresso social, apoiado no conhecimento.

\footnotetext{
Universalismo, compreensão entre os povos, interesse e ideais humanísticos: eis aqui o resultado do desenvolvimento do pensamento geográfico no homem. Na formação do jornalista, que maneja um dos mais poderosos instrumentos de ação social, essa predisposição, essa atitude é particularmente importante, pelas possibilidades que oferece de influir na opinião pública através da criação ou do fortalecimento, na imprensa, de objetivos mais altos que a simples satisfação da curiosidade dos leitores (JOBIM, 1964, p.75)
}

Como já citamos anteriormente, Jobim defendia que na Geografia a ênfase deve ser dada à Geografia Humana. Para ele, é tarefa do jornalista descrever a aventuras do homem em seu meio, assim como para o geógrafo. Mas este estará amparado por diferentes áreas de especialidade da Geografia, utilizando a colaboração de ciências físicas, biológicas e sociais. Ao jornalista, pelo contrário, importa principalmente a relação da 
Geografia com as ciências sociais, que são aquelas que olham diretamente o homem em ação na superfície da Terra.

Jobim utiliza o currículo da então Escola de Jornalismo da Faculdade Nacional de Filosofia e Letras da Universidade do Brasil como o modelo adequado de ensino de Geografia para jornalistas. Reservava-se um ano letivo à disciplina e a matéria se dividia em duas partes: o primeiro semestre era destinado ao estudo de Geografia Humana e o segundo era voltado à Geografia Econômica.

Dessa forma, a primeira parte voltava-se aos princípios e noções essenciais da Geografia, passando-se ao estudo das populações e ao estudo do "habitat", onde os alunos tratavam de questões como "a distribuição geográfica, a composição das populações, os movimentos migratórios, a colonização, assim como os tipos de habitação, a noção do habitat rural e do habitat urbano, com o estudo da cidade como paisagem geográfica e dos tipos funcionais de cidade".

No segundo semestre, associavam as regiões naturais ao seu aproveitamento pelo homem, tratavam da questão agrícola e industrial e da circulação de riquezas, incluindo os problemas relativos aos transportes. Jobim acrescenta que o programa da geografia humana não era distinto do programa destinado a formar geógrafos. O enfoque da matéria é que determinava as diferenças de objetivo, assim como as técnicas de ensino. 


\section{O ensino da História para jornalistas}

Assim como a Geografia, a História é essencial dentro dos estudos jornalísticos. Isto porque para descrever e interpretar os fatos do presente é necessário entender suas raízes que estão no passado. "Não se conseguiria explicar, evidentemente, as forças sociais que atuam em nossos dias senão pelo estudo de sua evolução, que é a própria história”, assegura Jobim, para quem retratar uma imagem do presente só é possível através da reconstrução do passado.

A profissão de jornalista é a que mais, além da de historiador, requer consciência histórica. E embora o historiador e o jornalista tenham perspectivas diferentes, porque o passado para o jornalismo é o dia de ontem, o método de trabalho dos dois é semelhante. O repórter investiga e, de certa forma, descreve a história e tenta interpretar. Mesmo não sendo ainda história, será dentro de algum tempo. Os passos para levantar os fatos são os mesmos: pesquisa, seleção, descrição e crítica. Isto, hoje, é notícia. Mas é fundamental reconhecer o papel do repórter que, em seus dias, cumpre sua tarefa de transmissão da história de amanhã. E é por essa razão que o acervo dos jornais oferece dados fundamentais para os historiadores.

Mas como realizar essa tarefa sem ter clara uma imagem do seu tempo e a base de cultura que proporcione essa compreensão? Aí está a importância da História: é através do seu estudo que será proporcionado ao futuro jornalista a mentalidade histórica, a capacidade de dar à notícia 
de jornal um valor permanente, uma importância que "transcende o conceito do efêmero cotidiano".

Talvez, por isso, John Bevin (apud JOBIM, 1964) tenha escrito acerca do noticiário do Times, de Londres, "um jornal culto para gente culta": "O Times não considera a notícia como um fenômeno isolado, mas sim como uma ruga na superfície da História".

O curso de História não pretende, assim como o de Geografia, formar especialistas. Tem como função fazer com que o estudante adquira uma base de cultura histórica visando uma atitude profissional para o uso desses fatos.

Mas que aspectos da História se deve ensinar? Jobim responde: aqueles que "melhor se ajustam à finalidade do curso". História da Civilização, por exemplo, é "a disciplina que assegura uma visão total da evolução das instituições; que põe ênfase na unidade da história humana; que acentua o caráter artificial da divisão da história em períodos cronológicos". Apesar do seu caráter formativo, deve ter para o jornalista um caráter muito mais informativo. É importante que o estudante tenha idéia das bases econômicas, sociais e políticas de que se serviram as sociedades mais remotas, para entender a evolução dos povos. A compreensão da história contemporânea só é possível com uma visão de conjunto da história humana.

Dewey (1936) também acredita que a História tem, por excelência, um caráter informativo. Isto porque põe em relevo aspectos sociais do 
homem, ou melhor, a vida em sociedade, assim como o ambiente desses acontecimentos, que é a natureza.

Quando nos esquecemos desta interdependência do estudo da história, que põe em relevo o elemento humano, com o estudo da geografia, que salienta o elemento natural, a história degrada-se tornando-se uma lista de datas, comum apêndice de acontecimentos rotulados de "importantes"; ou então convertese em fantasia literária - pois na história puramente literária o ambiente natural é apenas uma encenação teatral (DEWEY, 1936, p. 266-267).

O passado, simplesmente como passado, não nos interessa. Mas o passado de que trata a História é a história do presente. A partir do estudo das descobertas, exploração e colonização de um país, isto é, da sua formação, tem-se a compreensão do país nos dias atuais, de aspectos complexos que poderiam não ser facilmente entendidos partindo de uma análise isolada.

O estudo biográfico também reconstitui as vidas de grandes homens da história, trazendo luz aos episódios que seriam incompreendidos. Esse tipo de análise não deve ser isolada, ligada unicamente a aspectos psicológicos dos indivíduos, mas deve considerar os atos do homens com a vida social, que é a associação de indivíduos.

O estudo da vida primitiva fornece os elementos necessários para entender a história das indústrias. Compreende-se o percurso por qual passou a humanidade, os problemas que precisaram ser vencidos com as sucessivas invenções que possibilitaram o desenvolvimento da cultura 
humana, a partir da compreensão de como foram resolvidos os problemas fundamentais de subsistência, abrigo e proteção dos povos primitivos. Dessa forma, além de nos proporcionar as razões do progresso social, remete-nos a condições importantes da vida humana, como os valores que associam o trabalho à recompensa.

Esse ramo da História dá oportunidades de se entender o desenvolvimento científico e a luta do homem por uma progressiva adaptação das forças naturais para usos sociais, proporcionando conhecer os avanços dos métodos e resultados do conhecimento. Destaca não os generais, os diplomatas e os políticos, mas os cientistas que forneceram ao homem instrumentos de progresso da civilização, apontando a superação dos obstáculos pela inteligência.

A História também é responsável pela transmissão de valores éticos. Traz, a partir da análise de tempos passados, a compreensão das forças que criaram os padrões atuais de comportamento social. Aponta questões morais sobre virtudes e vícios. Mostra a construção da base moral da sociedade.

Este é um ponto fundamental na formação dos jornalistas, principalmente considerando o papel que a imprensa tem na sociedade, como orientadora e formadora de opinião. Jobim (1964) lembra que, nesse aspecto, o ensino da história nacional deverá considerar as questões éticas da história do país, servindo como instrumento de aperfeiçoar a questão da cidadania. 
A História Contemporânea deve ser priorizada em razão do seu caráter quase profissional para o jornalista, já que é uma ferramenta imprescindível em seu ofício. A união dessas duas contempla a proximidade no espaço (História Nacional) com a proximidade no tempo (História Contemporânea), aspectos que estão associados aos interesses da notícia.

\subsubsection{O ensino da Língua e da Literatura na Escola de Jornalismo}

Considerada por Cunningham (1975) como a disciplina da expressão, o ensino da língua apresenta dois aspectos: o primeiro relaciona-se com o treinamento para o aluno exprimir suas próprias idéias no discurso falado ou escrito; e o segundo visa capacitar o estudante a compreender as idéias alheias. Pode-se dizer que a responsabilidade por esse ensino está nos cursos fundamental e secundário. No entanto, essa não é a realidade encontrada entre os alunos ingressantes nos cursos superiores.

Por essa razão, é uma das disciplinas obrigatórias em qualquer escola de jornalismo. É tão essencial que Jobim resiste em classificá-la entre as matérias não profissionais. Sem o estudo da língua seria impossível, com certeza, formar um bom jornalista. O bom manejo do idioma "é condição essencial, básica, para o correto exercício da profissão de redator e de repórter". 
O professor lembra que a história do jornalismo já conviveu com episódios onde a figura do "jornalista analfabeto" esteve presente, principalmente com a introdução do modelo da imprensa norte-americana nas redações, quando se valorizou o repórter que trabalhava, não com a cabeça, mas sim com as pernas, o que caminhava em busca de notícias. A questão se tornou mais grave quando a legislação brasileira considerou jornalistas os "profissionais que informavam por telefone sobre acidentes e crimes, ainda que não escrevessem". Jobim queixa-se de que naquele momento privava-se o ofício de seu "status de profissão culta, no plano das profissões liberais".

Mas essa não é a formação que a escola de jornalismo pretende dar aos seus alunos. Sua proposta não é ensinar a narrar os fatos por telefone ou oralmente, mas formar um profissional que possa narrá-los ao público por escrito, com os atributos e normas da língua, com clareza, correção e concisão. Principalmente por ser um instrumento indispensável para a comunicação entre os homens, é fundamental para o desempenho da profissão jornalística, que exige a reflexão sobre os fatos.

A capacidade de se expressar do ser humano por meio de uma linguagem articulada nada mais é do que uma conseqüência do ato de pensar. Através dessas duas faculdades - o pensamento e a expressão -, o homem, com o passar dos séculos, acumulou o que chamamos de herança social (CUNNINGHAM, 1975). A linguagem não é a única forma de expressão humana, mas são as palavras que predominam no exercício 
dessa função. Mais do que um meio de comunicação, a linguagem é um instrumento do pensamento.

Como dissemos, é inadmissível formar um profissional cuja atividade se exerce através da interpretação dos acontecimentos, sem conduzi-lo ao manejo adequado da língua, disciplinando sua mente para o exercício das funções intelectuais necessárias para o desenvolvimento do de seu ofício, já que a linguagem nos apresenta um juízo de fatos e um juízo de valor.

A língua é um instrumento intelectual criado para representar idéias, pensamentos e emoções. As questões do nosso mundo interior, as questões afetivas, são exteriorizadas verbalmente em termos intelectivos, tomando a forma de idéias, de ordenação intelectual. Mas é também um instrumento cultural, já que é por meio do seu aprendizado que entramos em contato com os "valores culturais traduzidos pela literatura".

Para Jobim, o aprendizado da língua deve ser predominantemente literário, sempre vinculado à interpretação dos textos. Mesmo com a linguagem não tendo uma finalidade estética, sua função é biológica e social e traz um aspecto de criação artística. Dessa forma, apóia sua opinião nas idéias de Luiz Juan Guerrero (apud MIRANDA SANTOS, 1955), que assegura que:

No relato mais simples, na carta mais simples ou na lição mais repetida, pomos uma veio de poesia que apenas se percebe algumas vezes, mas que em outras vezes transforma tudo o que dissemos. 
Jobim ressalta que o valor do estudo da literatura não está apenas no caráter normativo da matéria, mas na possibilidade de acompanhar a experiência humana ricamente disponível na literatura. "Através da leitura vivemos experiências alheias, voltamos a formular questões, voltamos a pensar soluções, reações e sugestões, aprendemos coisas”, explica o autor, garantindo que o único método de aprender é viver os problemas que a vida apresenta. Ou como afirma Clotilde Rezzano (apud JOBIM, 1964): "Sem experiência pessoal não há idéias; sem idéias as palavras não têm conteúdo ideológico (...)".

Num curso de jornalismo, é fundamental que o professor de língua e literatura trabalhe em parceria com os professores de técnicas de jornalismo. É evidente que os textos utilizados devam ser textos literários, mas podem incluir textos jornalísticos de valor literário, já que o aluno trabalha textos jornalísticos em demasia na disciplina específica. Mas um bom método de ensino está apoiado no estudo de texto e na prática da redação, seguindo a recomendação do "aprender fazendo", comum durante todo período de aprendizado. É a partir do treino da escrita que se forja o bom estilo. E é a partir da leitura de grandes obras, onde se encontram "as mais puras e elevadas formas de expressão", que se aprende a escrever bem. 


\subsubsection{Ensino das disciplinas profissionais}

Após tratarmos da base cultural necessária a um profissional de jornalismo, abordaremos a visão de Jobim sobre as disciplinas técnicas do curso, ou do que Jobim chama de disciplinas profissionais. É importante lembrar que, naquele momento, poucas disciplinas desse tipo faziam parte do currículo do curso da Universidade do Brasil: Técnica de periódico diário, Técnica de periódico não diário, Administração de periódicos, Publicidade e Radiojornalismo.

Embora Jobim levante a questão da necessidade de equipamentos, percebe-se que essa questão está ligada à motivação dos alunos. Um dos meios de se motivar é procurar dar aos alunos uma atmosfera jornalística, o que ele acredita ser possível por meio de uma redação-escola. Assim, seria possível colocar o aluno em contato com a atmosfera jornalística, trabalhando as fases do processo jornalístico de forma mais próxima possível da realidade. Essa redação deveria ter os mesmos equipamentos disponíveis em uma redação tradicional, e a cobrança de prazos também deveria ser semelhante à realizada num jornal, com o maior controle possível das atividades realizadas pelos alunos. Eles seriam responsáveis por todo o processo, desde a redação das notícias até a montagem final do jornal.

Por isso, a redação-escola deve ser complementada com um laboratório gráfico, com técnicos capazes de executar os projetos 
elaborados pelos alunos, sob a coordenação do professor. Jobim (1964, p.19) explica a importância desse trabalho:

\begin{abstract}
Os alunos-jornalistas precisam trabalhar, em aula ou fora dela, em tarefas jornalísticas com a disposição de espírito de quem deve formar textos que serão compostos, impressos e distribuídos. Deve saber que não está brincando de jornalismo quando o professor, operando como chefe de redação, o instrui a averiguar e relatar uma notícia, fazer uma entrevista ou elaborar um comentário. Deve assegurar-se de que sua obra vai ser amplamente divulgada, lida e possivelmente criticada por seus colegas e por profissionais interessados nas experiências do curso. Isso provocará nos alunos o amor próprio e estimulará o sentido da responsabilidade, fazendo com que eles levem a sério as tarefas práticas.
\end{abstract}

Como já dissemos, o professor vê essas atividades práticas como fator de motivação do estudante, entendendo que o fato de ver sua matéria publicada levará o aluno a produzir com seriedade seu trabalho.

Mas sabemos que, na realidade, não são todas as escolas que proporcionam laboratórios adequados aos estudantes e nem mesmo a possibilidade de verem seus trabalhos publicados em jornais-laboratórios ou revistas, embora a legislação exija que assim seja. Muitos jornalistas formados passaram pelas escolas sem ter a oportunidade de ver seus textos aproveitados, não por falta de qualidade, mas por falta de laboratórios adequados ou veículos apropriados.

Como agir o professor diante dessa situação? Como ensinar a prática sem as condições necessárias? Este, sem dúvida, é um dos maiores desafios impostos aos mestres, que, diante de problema não devem desanimar. É verdade que um ambiente adequado, próximo do 
profissional, ajuda as atividades. Mas um jornalista escreve suas matérias em qualquer lugar, não necessariamente dentro da redação. A organização das atividades adequadamente deve ser a resposta do professor à falta de espaços e equipamentos úteis, mas não imprescindíveis. É nesse momento que a habilidade do professor se sobressai, levando os alunos a superar as falhas pela ausência dos meios auxiliares.

Um bom plano de ensino pode prever e superar os percalços causados pela falta de equipamentos. O professor deve prever modelos substitutos para as atividades práticas. Se a escola não tem ambientes próximos aos dos jornais, é importante levar os alunos a visitar redações para que possam entender seu funcionamento.

Jobim sugeria que o professor, além de publicar jornais-laboratórios, buscasse acordos com empresas jornalísticas para a publicação de trabalhos selecionados dos alunos, revisados pelo docente e escolhidos entre os melhores. Mesmo que exista uma publicação do curso, a possibilidade de o aluno publicar num veículo externo pode se constituir num excelente meio de despertar seu interesse e produzir resultados de grande qualidade.

Nesse ponto, o autor enfatiza um dos pontos cruciais do ensino do jornalismo: a relação da escola com as empresas jornalísticas, que são as que se beneficiam da formação adequada do aluno. Nesse ponto, é importante levantar questionamentos que se diferem da visão de Jobim. Enquanto ele entendia que essa aproximação era fundamental para o 
ensino do jornalismo, muitos pesquisadores mais recentemente discutem o papel do curso não como um mero repetidor do que se faz no meio profissional, mas como capaz de criar novos modelos e de melhorar a qualidade do jornalismo que se pratica.

É bem verdade que a universidade tem um papel que vai além da mera adestração do profissional. Ela tem como objetivo, como lembra Paulo Renato Souza (1990-1991, p.30), a busca pela qualidade acadêmica, porque "mesmo inserida num país de terceiro mundo, mesmo sustentada por uma sociedade que apresenta ainda carências bem elementares para parcelas significativas do seu todo, a universidade deve buscar o seu valor universal. Mas, da mesma forma, como ressalta o autor, deve buscar "o grau de vinculação ou conexão com a sociedade na qual se insere e que lhe dá sustentação".

Por isso, Jobim entendia que era essencial o contato permanente da universidade com o mercado, que deveria abrir oportunidades para que os estudantes praticassem sua futura profissão dentro das empresas. Mas deixava claro que esse processo não deveria ser percorrido sozinho pelo aluno. Não se tratava apenas de abrir espaço para que o estudante pudesse atuar, mas de possibilitar que o professor acompanhasse suas atividades. Com sua prática nas redações, Jobim percebia que o aluno abandonado numa redação adquire rapidamente os erros e vícios dos profissionais mais medíocres que, embora não sejam os mais qualificados para servirem de instrutores, são os que geralmente estão disponíveis para tais fins. 
Assim, é incrível a avidez com que o estudante se apodera do jargão jornalístico naquilo que tem de detestável: a insistência no uso de expressões estereotipadas e convencionais, que matam na origem a vivacidade do estilo, como a riqueza, a plasticidade e a propriedade da linguagem. Tal insistência cria hábitos condenáveis, verdadeiros jargões expressionais, que a escola dificilmente extirpará. Adotam certo garbo os recém chegados à redação, escrevendo não na língua usual ou na literária, mas naquela que os americanos chamam, pejorativamente, o journaleese. (JOBIM, 1964, p.22)

Desse modo, o aluno poderá fazer sua prática, desde que não lhe falte a supervisão e a orientação do professor que, embora não possa estar presente ao lado do estudante em seu período de trabalho, poderá acompanhar por meio de um relato e um dossiê preparado pelo aluno as atividades e o material por ele produzido na redação. Esse material serviria não apenas a uma avaliação pessoal do estudante, mas como objeto de reflexão e análise da turma, além de auxiliar ao próprio professor como uma avaliação pessoal da matéria dada em sala de aula.

Esse acompanhamento irá possibilitar, inclusive, que o aluno adquira uma atitude crítica a respeito da rotina do trabalho jornalístico, "eliminando o perigo de uma posição passiva ante os elementos negativos dessa rotina", o que Jobim acredita ser um sério fator de perturbação no processo de aprendizagem. A partir dessa crítica, o estudante poderá produzir trabalhos de maior fôlego sobre a atividade jornalística, como ensaios ou monografias. O autor comenta, como exemplo, a série publicada com trabalhos desse tipo que foi realizada por alunos da Escola Oficial de Jornalismo de Madrid, sob a direção de Juan Beneyto. 
A análise da história de jornais, suas linhas editoriais, suas tradições, suas orientações políticas, seus projetos gráficos, suas formas de redação e apresentação das notícias e diversos outros aspectos da vida do jornal poderiam ser tratados, contribuindo com a reflexão crítica dos veículos e suas formas de "fazer jornalismo". Evidentemente que os alunos poderão se ater a aspectos que sejam de maior interesse ou mais atuais dentro do plano de estudos proposto pela disciplina. Mas toda informação que o aluno praticante trouxer para a sala de aula será de utilidade como objeto de análise em sala de aula.

Da mesma forma, Jobim acredita que a análise dos manuais de redação pelos alunos também pode ser uma excelente forma de aprendizagem. Mesmo com toda crítica que se fazia na época à chamada "folha de estilo", ele confiava que era uma louvável tentativa para "melhorar a qualidade do relato jornalístico".

Referia-se a críticas como as formuladas pelo diretor do jornal norte-americano Detroit Free Press, Malcom S. Binguy, que chamava o manual de "camisa de força", defendendo que o estilo é "um reflexo da personalidade de quem escreve" e não se adquire com leituras sobre o assunto. "O único que se pode exigir é boa gramática, bom gosto e bom sentido" (apud Ph. Porter, Manual de Jornalismo, Havana, 1943). Esta posição contrapunha-se com a de Jobim, que acreditava que os manuais não privavam o jornalista da espontaneidade e nem prejudicam o estilo pessoal de cada um, apenas ajudavam a organizar o texto. 
Mas, voltando ao estudo do manual em sala de aula, o professor defende que a análise de diferentes manuais permite que o estudante se confronte concretamente com os pontos básicos do aprendizado da redação para jornais, considerando individualmente as dificuldades que vão se deparar dentro da profissão. Entretanto, levanta uma questão fundamental: a visão do aluno não deve ser passiva. Pelo contrário, deve ser crítica em relação aos problemas de estilo, já que as regras podem, efetivamente, não apresentar as melhores soluções, dependendo da circunstância.

O professor deve, no início do curso, analisar as condições de preparação dos estudantes. A partir dessa sondagem e prognóstico do aprendizado, é que ele poderá desenvolver o planejamento das atividades, definindo os métodos que deverá empregar. A avaliação periódica dos alunos vai demonstrar quais são as maiores dificuldades que os alunos encontram. Isso possibilitará a mudança nos planos de ensino e a correção das deficiências. A avaliação do estudante vai demonstrar, segundo Jobim, não apenas o sucesso do aluno, mas o do professor e de seus métodos. 


\subsection{0 método de ensino}

"Por certo que há uma pedagogia do ensino superior", repete Jobim, referindo-se à frase do professor Almeida Júnior13, alertando, porém, que o ensino de adultos permite, por suas "faculdades de abstração e generalização", que o professor se utilize mais livremente do método expositivo. Trata-se de um nível de ensino com preceitos mais flexíveis, com funções formadoras da cultura humana, que concede aos mestres uma iniciativa didática mais livre do que nos outros níveis. Jobim acredita que, nesse caso, os professores estariam subordinados unicamente, a dois princípios: "o do respeito à verdade e o da eficiência".

O autor acredita que cada professor pode encontrar o método mais adequado, a partir de sua própria experiência no ensino superior. Entretanto, oferece, a partir de sua própria experiência e através de observação dos colegas, sugestões sobre métodos de ensino de diferentes matérias no curso de jornalismo.

O método, como já sabemos, "é a sistemática, o princípio geral que pretende organizar ou racionalizar a conquista do objeto", determinado através das técnicas que indicam os meios trilhados para a obtenção do resultado. São os métodos que vão determinar a resposta à pergunta

\footnotetext{
${ }^{13}$ Jobim cita a frase de Almeida Júnior, extraída do ensaio “A técnica do ensino em função das finalidades do ensino superior”.
} 
"como ensinar?", ou, como sugerem os modernos princípios didáticos, “como ajudar o aluno a aprender?".

A "cadeia didática" considera seis elementos: o objetivo, a matéria, o meio, o aluno, o professor e as técnicas de ensino, todos intimamente relacionados na realidade escolar. Essa combinação permite que existam diferentes métodos. No entanto, Jobim considera que o professor não deve se prender unicamente a um método, já que são as circunstâncias que geralmente apontam o método a empregar. A técnica de ensino pode variar de expositiva para a de execução de tarefas, para a de resolução de problemas, para a inquisitiva, e assim por diante. Sem dúvida, a experiência é que vai determinar ao professor qual é a adequada naquele momento para motivar o aluno.

Voltamos, assim, à questão da motivação de que já tratamos antes, para lembrar que esse princípio estabelece que "só se aprende o que se quer realmente aprender", ou o que traz interesse para o aluno. Por isso, qualquer método utilizado não pode ser considerado eficiente se não priorizar o interesse.

É preciso criar essa atmosfera de satisfação, às vezes até de entusiasmo, que deve envolver a aprendizagem, para que esta seja verdadeiramente fecunda, e para que o estudante participe por inteiro do processo. Quando a tarefa nos absorve, então estamos participando da atividade criadora; para usar linguagem didática, estamos sendo motivados, isto é, incitados, impelidos a aprender alguma coisa (JOBIM, 1964, p. 54-55). 
Jobim refere-se à técnica ideal como sendo aquela que tivesse a participação integral do aluno no processo de aprendizagem, considerando as três funções da mente:

$1^{\circ}$. - a mente cognoscitiva que leva à percepção, ao conhecimento, e finalmente à compreensão da vida;

$2^{\circ}$. - a mente afetiva, que assegura a motivação, o condicionamento de atitudes, e, por essa via, a alegria de viver; e

$3^{\circ}$. - a mente conativa, que conduz à auto-atividade, à aquisição de habilidades e, por conseqüência, ao controle da vida.

(JOBIM, 1964, p. 55)

É o que Cunningham (1975) define como os três princípios da aprendizagem humana: o princípio da auto-atividade, o princípio da motivação e o princípio da percepção. Esses princípios, segundo o autor, foram formulados por diferentes pensadores ao longo da história das idéias: desde Aristóteles14 e São Tomás de Aquino15, no caso da autoatividade; Dewey, no caso da motivação; e Herbart16, no caso da percepção.

O bom aluno de jornalismo, assegura Jobim, é o que pretende ser um bom jornalista. É esse objetivo que produzirá maior esforço para alcançá-lo. Identificar o propósito, a razão de ser e o objetivo do esforço

\footnotetext{
14 “O intelecto aperfeiçoa-se, não pelo conhecimento, mas pela atividade”, em "Ética e Nicômaco”, apud Cunningham, 1975, p. 118.

15 “Assim como se diz que o médico devolve a saúde a uma pessoa enferma, pela ação da natureza, assim também o homem desperta o conhecimento em outro fazendo agir a razão natural do que aprende”, trad. Mary Ellen Mayer, in "The philosophy of teaching of St. Thomas Aquinas", apud Cunningham, 1975, p. 118.

${ }^{16}$ Considerado o "primeiro psicólogo educacional”.
} 
fará com que o estudante compreenda o que faz, possibilitando que faça melhor. Por essa razão, é importante que não se perca de vista os objetivos na determinação dos métodos. E a sistematização das tarefas resultará em economia de tempo e de esforço, pelo emprego do método adequado.

É o caso de se pensar como ensinar as disciplinas não técnicas sem perder de vista os objetivos da formação do jornalista. O professor deve questionar o que vai ensinar, a quem vai ensinar, por que vai ensinar e quais os meios que dispõe para ensinar e, então, definir como vai ensinar.

Para Jobim, o elo das disciplinas com o jornalismo está na questão da atualidade, "por meio das conexões entre os fatos mais remotos, no tempo e no espaço, e a atualidade mais viva, descrita nas páginas dos jornais de nossos dias". Segundo o autor, "no passado somente existe o presente", relembrando Ortega e Gasset, quando afirmam que "não há ação na distância (...) O passado não está ali, numa data, porém está em mim. O passado sou eu, quer dizer, minha vida". O jornalismo reclama esse vínculo com o passado, que contribui para que o aluno compreenda seu tempo.

É o caso, por exemplo, do ensino de História no curso de Jornalismo. Os métodos não devem ser muito diferentes dos aplicados num curso de História. Porém, é preciso considerar que a função deve ser muito mais formativa do que informativa. Isto porque, no jornalismo, a história é apenas um dos numerosos componentes da cultura geral. 
Outra questão diz respeito ao tempo que se destina ao seu estudo, que deve ser muito mais limitado do que o que se reserva em um curso de História. No entanto, Jobim (1964, p.66) relembra as palavras do professor Gérman Carrera Damas, para quem a mais importante conquista que pode fazer um estudante de História é a de, na presença de um problema, compreender e saber situá-lo historicamente,

\begin{abstract}
aproximar-se dele de forma gradual até chegar a formar uma compreensão inicial de sua estrutura; dispor racionalmente do equipamento documental e técnico apropriado; realizar metodicamente o estudo do problema até alcançar sua compreensão; organizar os resultados desse estudo com adaptado a um plano ajustado criticamente, e estar, por último, em atitude de enfrentar-se uma redação (ou exposição oral do discurso, empregando uma linguagem apropriada).
\end{abstract}

Trata-se, na verdade da aquisição do método e da assimilação das técnicas de investigação, que serão úteis não apenas para o futuro historiador, mas também fundamentais para o futuro jornalista. "Nem um nem outro vão aprender história propriamente: mas sim aprender como aprendê-la". A chave para o professor é dar os rumos para que o aluno possa investigar e compreender um processo histórico, única orientação possível, segundo Jobim, dentro de um curso superior, caracterizado por uma atividade de investigação precursora nos domínios da cultura. "Mais que o ciclo secundário da educação, o superior oferece o método, o instrumento, a ferramenta para trabalhar a matéria, o esforço criador. O formativo ultrapassando o informativo" (Jobim, 1964, p. 66). 
Vejamos um caso que Jobim comenta, a partir do ensino de História oferecido no curso de Jornalismo da Universidade do Brasil ${ }^{17}$. De um modo geral, os métodos didáticos podem ser os mesmo que os empregados no curso de História, mas levam em conta o objetivo do ensino: no curso de História, o aluno é preparado para ensinar e para a exposição oral; no curso de Jornalismo, o estudante é preparado para informar, para escrever, redigindo notícias, elaborando comentários e explicando por escrito.

Por isso, o conteúdo das aulas acabam sendo complementadas por atividades extra-classe, que se transformam em atividades de investigação jornalística, em pequenas reportagens. Como exemplo, o professor escolhe um determinado assunto da atualidade, como um conflito que envolve um determinado país. O caso é trabalhado em sala de aula, comentando-se o episódio, a localização geográfica e demais informações. Como atividade externa, os alunos ficam encarregados de conseguir artigos, mapas e ilustração sobre o assunto. Como trabalho, devem redigir, num número pré-fixado de linhas - como forma de treinar a concisão -, os dados complementares que conseguiram sobre aquele conflito ou país, utilizando o estilo jornalístico.

Jobim enfatiza que a problematização e a investigação ajudam no processo de compreensão. A aprendizagem não se sustenta pela memorização, que não é a base desejável em nenhum ciclo educativo,

\footnotetext{
17 O professor responsável pela disciplina História Contemporânea era Delgado de Carvalho, professor emérito da Faculdade Nacional de Filosofia da Universidade do Brasil, criador da cátedra de História no curso de Jornalismo.
} 
muito menos no universitário. "Um mínimo de memorização deve auxiliar o máximo de interpretação lógica de sólidos conhecimentos. A aprendizagem se assenta numa perfeita integração dos elementos culturais na mente do aluno".

Nesse sentido, ele sugere que deva ser permitida ao aluno a consulta aos apontamentos de classe, dicionários, mapas, livros e documentos durante a realização das provas. Acredita que, no momento da avaliação, o estudante de jornalismo vai poder revelar sua capacidade profissional, com clareza, concisão e exatidão. Por isso, defende que, embora se possa utilizar diferentes tipos de provas, a aprendizagem do futuro jornalista se verifica principalmente através da exposição escrita, que não deve ser uma exposição literária, mas seguindo as normas de um bom texto jornalístico: conciso, preciso, calculado para um determinado espaço de linhas, e que resulte de um plano de informação para um determinado público.

Os materiais pedagógicos devem ser compostos por anuários, livros, publicações periódicas, dados estatísticos, biografias, mapas etc. Mas também devem ser utilizados artigos de jornais e revistas nacionais e estrangeiras. Além disso, devem ser indicados títulos que possam contribuir para o aprimoramento das informações.

Vejamos agora o caso do ensino de Geografia. Jobim comenta especificamente a disciplina de Geografia Humana ministrada no curso de Jornalismo da Universidade do Brasil, onde o ensino de Geografia Humana ocorria durante um ano, com duas aulas semanais, metade do 
que era oferecido a esta disciplina no curso de Geografia $^{18}$ da mesma Universidade. Era a metade do período destinado a esta matéria no curso de Geografia, o que demonstra que a diferença entre o que era oferecido nos dois cursos se baseava na menor intensidade e profundidade no estudo, já que os programas não apresentavam grandes diferenças.

Mas os objetivos, assim como no caso de História, eram distintos. Pretendia-se, no curso de Geografia, formar professores ou investigadores na área. No caso do Jornalismo, pretendia-se formar jornalistas com um "bom conhecimento dos problemas do mundo contemporâneo, relacionados com a geografia", matéria que faz parte de um complexo de conhecimentos gerais que se julgam ser imprescindíveis em jornalismo.

E como esta disciplina era ensinada na Universidade do Brasil? Jobim explica que em sala de aula utilizava-se principalmente o método expositivo, forma de esgotar o programa do ano letivo. Mas não era o único. O professor trabalhava com leituras individuais orientadas e com atividades em grupos com temas que exigiam dos alunos: busca bibliográfica, exposição geral e debate em classe. Jobim acredita que, embora essas práticas nada tenham de original, contribuem para a formação do repórter, porque criam hábitos orientados para a investigação e para o levantamento de dados corretos, o que redunda de forma positiva no exercício diário do jornalista.

\footnotetext{
${ }^{18}$ No curso de Geografia, a disciplina era oferecida pelo período de dois anos, com quatro aulas semanais.
} 
Um exemplo prático trazido por Jobim refere-se ao tópico "Estudo geográfico das populações", com o tema "colonizações". Como o objetivo é que não se perca de vista o objetivo mais amplo, a formação do jornalista, a motivação, no caso, nasce da própria atualidade do problema do colonialismo. "O interesse dos alunos pelos movimentos africanos de emancipação os incita a acompanhar e possivelmente a participar do estudo da questão", explica Jobim, ressaltando que o assunto foi notícia de primeira página nos jornais.

O autor insiste que o principal é evitar a inatividade entre os alunos. O professor deve planejar cuidadosa e logicamente as atividades para que não se transformem em fracassos, regra que, segundo Jobim, "deve ser aplicada a qualquer atividade docente".

No caso do estudo da língua, Jobim sugere que se utilize as seguintes técnicas:

a) Leitura interpretativa de textos literários e textos especializados, como de textos selecionados de jornais.

b) Redação de textos, preferencialmente jornalísticos, como reportagens, notícias, crônicas e editoriais.

c) Análise da estrutura da língua, em função da interpretação dos textos referidos.

Nesse caso, apresenta o trabalho desenvolvido no curso de Jornalismo da Universidade do Brasil, na disciplina Língua Portuguesa e 
Literatura $^{19}$, que tinha como objetivo "preparar o futuro profissional para expressar-se com correção, clareza, concisão, expressividade e, também, o que não é menos importante, com rapidez". É importante também para o estudante a cultura básica e não especializada oferecida pelo estudo da Literatura, que trata de pessoas e movimentos representativos, elementos ainda encontrados no movimento literário contemporâneo.

O programa da Universidade do Brasil era desenvolvido durante três anos, com três aulas semanais. No primeiro ano, trabalhava-se a língua portuguesa, com a revisão dos principais pontos do ensino, forma de reforçar a base que o estudante deve ter obtido no secundário, habilitando-o a escrever com correção e clareza. Depois, na segunda unidade, abordavam-se os estilos da língua portuguesa e a análise do discurso, o que colocava em evidência os recursos expressivos da língua portuguesa, proporcionando aos estudantes os elementos que vão ajudálos a redigir de maneira mais viva, oportuna e dinâmica. Ainda, no primeiro ano, enfatizava-se a redação, que deveria ser o resultado final dos estudos das duas primeiras etapas.

As atividades de leitura e análise de textos de livros, jornais e revistas pretendiam dar aos alunos a visão e solução dos problemas de estruturação e desenvolvimento de um relato, de acordo com a finalidade do mesmo, inclusive dos relatos jornalísticos, trabalhando também as características básicas do chamado "estilo jornalístico". Dessa forma,

\footnotetext{
${ }^{19}$ A responsável pela cátedra era a professora Célia T. G. de Veiga Oliveira.
} 
conduziam o aluno o mais rapidamente possível para o desenvolvimento de seus próprios textos, que sofriam uma crítica minuciosa posteriormente.

O método aplicado nessa primeira etapa levava em conta que o ensino deveria ser feito da maneira "mais prática e dinâmica possível", com o professor partindo sempre do aluno e de suas dificuldades. A exposição teórica vinha depois do exame de texto de autores modernos e de jornal e o aluno era estimulado a participar de debates em sala de aula.

No segundo ano, as aulas se voltam para o estudo da Literatura Portuguesa e, no terceiro ano, trabalhava-se a Literatura Brasileira. Antes de começar o curso de Literatura, o aluno era introduzido na teoria literária, para que se familiarizasse com o fenômeno literário e sua nomenclatura.

Os temas abordavam prosa e poesia, os gêneros literários, as escolas literárias e o folclore e a literatura oral. Enquanto da Idade Média portuguesa e da Literatura Clássica portuguesa e brasileira selecionava-se como objeto de estudo apenas os autores e as obras mais representativas, o panorama literário contemporâneo do Brasil e de Portugal constituía-se o eixo dos programas. A cada semestre se escolhia uma obra moderna (novela de preferência) para ser lida, comentada e estudada pelos alunos.

Como parte do programa, a crítica literária jornalística era tratada como forma de despertar o aluno para o assunto. Para isto, o professor cobrava a produção de resenhas analíticas de novelas e poemas, depois do estudo de autores e obras, e após comentários estilísticos de textos 
como críticas, resenhas ou colunas de apreciação literária dos principais suplementos e revistas.

A relação com a atualidade também era trabalhada, da mesma forma que nas disciplinas anteriores, buscando a motivação do aluno. No estudo da Literatura Medieval ou Clássica, procurava-se relacionar o fenômeno artístico em sua realidade histórica e social com suas vinculações com o presente. Da mesma forma que, quando da comemoração da epopéia dos grandes navegadores portugueses, exaltando-se a figura do Infante Dom Henrique, aproveitou-se o amplo noticiário da imprensa para, partindo dele, estudar o Quinhentismo Português e a literatura dos descobrimentos.

Jobim também cita o exemplo de que, quando os jornais comentaram que "vozes agourentas" se opunham ao programa de desenvolvimento nacional do governo Kubitschek, a referência motivou o estudo daquele episódio de "Os Lusíadas". Da mesma forma que, ao estudar o teatro de Gil Vicente, comparavam-se as obras desse autor clássico com a peça "O auto da Compadecida", de Ariano Suassuna, então em cartaz com grande sucesso.

Para evitar o excesso de aulas expositivas, atribuíam-se atividades de pesquisa aos alunos sobre diferentes autores e suas obras. Os resultados eram apresentados em seminários ou em mesas-redondas que incentivavam o debate. Jobim argumenta que exposições individuais propiciam ao aluno habilidades como as de naturalidade na apresentação, 
presença de espírito, boa dicção e prática da exposição oral, que com certeza auxiliam sua atividade na disciplina de radiojornalismo.

Mas como verificar o aprendizado do aluno nessa disciplina? Existem, é óbvio, os trabalhos realizados durante o semestre. Alguns são exercícios que tratam dos pontos teóricos debatidos em sala de aula, enquanto outros devem ser constituídos de trabalhos práticos, em forma de reportagens sobre um tema relacionado com a matéria ou de apreciação de uma obra literária. Estes últimos devem ter um peso maior, porque supõem uma preparação prévia, sob a forma de investigação e coleta de dados, que são realizados fora da sala de aula. A redação final deve ser feita em classe, quando o aluno pode consultar os elementos recolhidos previamente.

Embora os livros sejam fundamentais no ensino da Língua Portuguesa, materiais jornalísticos atuais não podem ser dispensados, seja para fins estritamente didáticos, seja para fins de motivação. O aluno deve sempre ser estimulado a ler jornais e revistas, podendo, muitas vezes, escolher páginas ou seções de dois jornais diferentes para discutir os aspectos redacionais ou estilísticos. É importante não ignorar o aspecto jornalístico, mesmo nas aulas de Língua e Literatura, e utilizar, sempre que possível, títulos, leads, textos de artigos, reportagens e crônicas, como forma de motivar o aluno de jornalismo.

Sobre o ensino das disciplinas profissionais, Jobim resume suas próprias atividades na disciplina que ministra na Universidade do Brasil, 
Técnica de Jornalismo, levantando inclusive a questão da Universidade não dispor, na época, de laboratório gráfico.

Vejamos o exemplo da lição, que trata da questão dos títulos nos jornais. Num primeiro momento, o professor faz uma introdução oral sobre o assunto, utilizando um exemplo atual: como os principais jornais do Rio de Janeiro anunciaram os primeiros resultados das eleições. O material didático utilizado são quatro exemplares dos jornais do dia, mais periódicos americanos e franceses. Os tópicos da exposição inicial abordam: a) conceito para o título; b) o título anunciando a notícia; c) o título sumarizando a notícia; d) o título classificando a notícia; e) o título integrando a página, compondo a fisionomia gráfica do jornal.

A atividade se desenvolve com o método e a lógica de construção do título - título rótulo e título sentença -, examinando também os modelos dos títulos de estilo americano e de estilo francês, seguido pelo estímulo a um debate sobre as causas das diferenças. Os alunos são convidados a, no quadro-negro, reproduzirem títulos "certos" e "errados", explicando a razão de conceituá-los dessa forma. Finalmente, a conclusão explica a função dos títulos, afirmando ou negando "o que há de essencial na notícia”.

O professor ainda solicita uma atividade a ser feita em casa, que consiste em selecionar dez títulos de jornais considerados "condenáveis", procurando modificá-los para melhorá-los. 
Dentro do mesmo tema - títulos -, uma segunda aula trata da estrutura e da linguagem do título, ou seja, sua redação. É uma aula essencialmente prática, onde os alunos deverão titular as matérias, de preferência pequenas notícias recortadas dos jornais do dia. Jobim explica que não deve ser exigida a contagem das letras, pois isso levará o estudante a se preocupar muito mais com a estrutura gráfica do que com o conteúdo, embora se deva insistir para que sejam concisos e objetivos.

Outro exemplo de aula trata do tema título em função da paginação. Jobim conta que exibia o jornal Pravda, discutindo a razão de os jornais da então União Soviética apresentarem títulos em caracteres tão pouco destacados e não seguirem a regra do título-sentença. Esse tema abre possibilidades de debater a imprensa nos regimes ditatoriais e seus reflexos no padrão gráfico dos jornais.

A partir do mesmo assunto, poderá se trabalhar o efeito da concorrência sobre os tipos de paginação, o que possibilita discutir sobre a "guerra dos títulos", ilustrando com títulos curiosos e até mesmo anedóticos, entre outros.

Apenas após todas essas questões o professor passará para os diversos tipos de preparação de paginação, com o uso de esquemas no quadro-negro. O aluno, a seguir, tentará reproduzir o diagrama onde a página de um dos jornais expostos foi concebida e projetada. Somente depois disso é que o professor ensinará ao grupo o diagrama da página enfocada, feita em papel adequado, e no formato do jornal, tal como feita pelo diagramador. Por ser uma peça autêntica, tem efeito motivador. 
Como lição de casa, o professor pode solicitar a confecção de novos diagramas reproduzindo jornais reais.

Outras aulas também técnicas são comentadas por Jobim, como as que tratam da variedade nas famílias tipográficas usadas, com exemplos selecionados da imprensa americana e da imprensa francesa, que discutem as razões técnicas, econômicas ou psicológicas para a escolha do formato do jornal, entre outras.

Mas os exemplos dados são suficientes para demonstrar técnicas de ensino de natureza profissional que podem valorizar a aula, mesmo sem equipamento adequado. "Sirva nossa experiência e nossas sugestões de incentivo aos que lutam com a pobreza de meios", considera Jobim, que sofria naquele momento do curso, de falta de meios auxiliares de ensino. Não que defendesse que o professor poderia trabalhar sem os equipamentos necessários, mas apenas como forma de demonstrar que é possível manter os alunos em atividade - o ele considera ser a regra de ouro do ensino -, mesmo na falta daqueles.

Porém, os exemplos das lições acima não significam que a ênfase da disciplina deva ser dada a esses aspectos da profissão. Pelo contrário, o autor considera que a ênfase do curso deva ser dada ao estudo da notícia, da informação propriamente dita. Mais do que isso, na "informação honestamente apresentada, respeitando a regra célebre: o comentário é livre, porém o fato é sagrado". 
Mesmo com a disciplina de ética estando presente na grade do curso, Jobim acredita que o que mais influenciará o aluno a agir eticamente na profissão é o professor que o ensinou a redigir. Ele é o responsável por transmitir o amor à exatidão e à objetividade, ou seja, "a consciência do mais alto de seus deveres, que é informar escrupulosamente aos leitores", preocupação que deve ser constante em todas as disciplinas do currículo, e não somente nas matérias culturais. Mesmo porque o ensino da elaboração da notícia propicia diversas situações que levam o aluno a refletir sobre as questões éticas da profissão, a partir de exemplos de notícias total ou parcialmente incorretas, que são resultado de negligência ou falta de atenção do repórter.

A questão ética está presente no plano de aula, disponibilizado por Jobim (1964, p. 43-44), que reproduzimos a seguir: 


\section{MODELO DO PROJETO DE CLASSE}

Professor: Danton Jobim Disciplina: TÉCNICA DE JORNALISMO

Faculdade Nacional de Filosofia - Jornalismo

Primeiro Curso

Plano de Classe - Tema: Introdução ao Sensacionalismo

Informativos: Iniciar a preparação do estudante para resolver os problemas de Técnica de Jornalismo originados pela aplicação dos princípios de ética profissional (tratamento adequado de crime, sexo, etc.).

\section{Objetivos:}

Formativos: Combater o sensacionalismo jornalístico sem desestimular a busca do "sensacional" e sem alimentar prejuízos contra a reportagem policial.

Motivação inicial: Referência e apresentação de revistas de escândalos.

Material didático: Um jornal e duas revistas de escândalos; um jornal ultra-popular, explorando excessivamente o gênero policial.

Apresentação da a) Sensação e Sensacionalismo;

matéria: $\quad$ b) Origens e evolução da reportagem policial;

$5 \mathrm{~m}$. c) $\mathrm{O}$ sensacionalismo nas matérias não policiais (política e sociedade). 
Desenvolvimento: a) Sexo como notícia: sex-appeal;

$20 \mathrm{~m}$. b) Crime, perigo social na divulgação de crimes bárbaros ou escabrosos;

c) "O Herói criminal" contrabalanceado pelo "Herói detetive" (tratamento construtivo);

d) Psicologia do contágio: os "Crimes do machadinho".

Motivação: Exibição na classe de fotografias de perícias de três crimes semelhantes.

$5 \mathrm{~m}$. (assassinatos cometidos por mulheres com um mesmo instrumento).

Rápido diálogo com Deve ser suprimido da imprensa o noticiário do crime? a classe sobre o tema: Enfocar nas contestações e comentários:
a) Opinião de psicólogos e neurologistas;
b) Opinião de jornalistas;
c) Tentativa de extinção nos Estados Unidos; caso do "Christian Science Monitor".

\section{Conclusão provisional}

do diálogo: $\quad 0$ jornal deve oferecer um retrato tão fiel quanto possivel, de sua comunidade, sem deformações nem mutilações.

Conclusão da classe: 0 crime é notícia, mas temos que dar-lhe um tratamento adequado para que se reduzam ao mínimo os perigos sociais de sua divulgação.

Tema da próxima classe: Problemas de redação e apresentação de notícias sensacionalistas, sem incorrer em sensacionalismo. 
Apesar das décadas que nos separam da elaboração deste plano de aula, sem dúvida, os temas propostos não se diferenciam em nada de uma aula atual, onde a questão da notícia, da ética, da valorização da informação e da importância do debate crítico devem ser essenciais.

Outra questão levantada por Jobim trata do jornal-laboratório. Se a escola não dispõe de um jornal próprio - ou, trazendo para a atualidade, apenas aparenta ter um jornal-laboratório para atender à legislação vigente - como treinar os alunos? A técnica da narração jornalística, segundo o professor, pode ser aprendida sem maiores dificuldades, porque o importante é que os alunos utilizem dados reais em seus exercícios e rigorosamente atuais. Esse, de acordo com o professor, é um dos grandes problemas do ensino das técnicas, já que esses conceitos sobre o jornalismo devem ser aplicados a situações familiares aos alunos. Em sua opinião, "os estudantes latinos americanos de nível universitário participam mais do mundo da idade adulta do que da adolescência", o que faz com que os alunos transpassem os temas do mundo escolar. Chega a ser difícil obter o interesse dos alunos na realização das tarefas que exploram assuntos da vida estudantil. Quando, ao contrário, o tema gira em torno da política ou de outro assunto publicado nos grandes jornais, o professor corre o risco de entrar em debates apaixonados.

Jobim acredita, no entanto, que quando se trata de ensinar ao aluno a redação de editoriais, o problema é mais simples. Num primeiro momento, deixa-se o estudante usar toda sua criatividade e liberdade de opinião para, depois, mostrar que não se deve escrever o que bem se 
entende numa redação. A melhor maneira de trabalhar esta questão é colocar o tema em debate em sala, examinando as várias faces do problema, e mostrar que a tese do editorial será a conclusão do debate, ou melhor, a conclusão do grupo. Essa forma de discussão vai garantir ao aluno maior informação e segurança na condução do raciocínio, "e - o que é importante - maior sentido de responsabilidade ao emitir a opinião da classe que, no futuro, será a opinião do jornal onde escreverá”.

Os temas tratados nos editoriais devem incluir discussões sobre as atividades estudantis, mas vale a ressalva feita sobre as notícias: os alunos se interessam menos por questões que envolvem sua vida acadêmica, até porque passam pouco tempo no espaço universitário.

Justamente, por essa razão, deve-se estimular as atividades extraclasse, que não costumam ser freqüentes no Brasil. Os alunos evitam atividades que os afastem do seu ritmo diário em uma grande cidade. Porém é importante estimular sua participação em diferentes manifestações que envolvam seu curso, como associações que tratam da questão da imprensa, cursos extra-curriculares e de extensão, além de outras mais que podem se somar à vida universitária.

Um tema interessante levantado por Jobim é a questão dos livros didáticos que dão suporte às disciplinas. Ele acredita que se "existe um profissional a quem interessa particularmente a utilização adequada dos manuais, este é o jornalista", que se dedica a um trabalho apressado e que requer objetividade. Nesse caso, os livros, manuais e compêndios são 
excelentes como instrumentos profissionais, que, mediante definições corretas, ajudam a entender a essência das coisas.

Ademais, são excelentes como "ponto de partida, como pontos de apoio na experiência consagrada" e têm uma função disciplinadora, fator essencial para o trabalho criativo, abreviando o caminho para o saber. No entanto, também oferece sérios riscos, segundo o autor, sendo o mais grave o risco de o aluno se deixar escravizar pelo texto, "em uma espécie de condicionamento de reflexos verbais que, sublimando a letra, rebaixa o espírito". A visão do estudante tem que ser crítica, fator essencial no ensino superior e estimulante para debates em sala de aula.

É o caso dos manuais de redação que, embora úteis, não são imprescindíveis. Melhor que, diz Jobim, são as anotações das noções recebidas enriquecidas com exemplos práticos. A bibliografia indicada no início do curso, deve ser ampliada por novas indicações ou até mesmo por iniciativa dos próprios alunos. Mas os livros devem passar por leituras críticas que estimulem o raciocínio.

Outro meio adaptável para o ensino do jornalismo é o audiovisual. Jobim conta que planejou, no curso da Universidade do Brasil, fazer um filme didático que abordasse todas as fases da produção jornalística, mas não obteve sucesso em razão da falta de recursos. A experiência seria inspirada na do professor Paul H. Wagner, produtor de "Police Reporter", o primeiro filme educativo a ser utilizado no ensino de um tema específico do jornalismo, de acordo com informações da revista Journalism Quarterly, edição do verão de 1950. Pesquisas realizadas após sua exibição na 
Universidade de Ohio indicaram que o filme foi mais eficaz para o ensino que uma conferência utilizando as mesmas informações descritas no documentário.

O setor de pesquisas da Divisão de Informação e de Educação do Exército Americano, motivado pelo êxito obtido com os vários métodos de apresentação audiovisuais, pesquisou o tema exaustivamente, em relação aos adultos, motivando observações como a de Charles F. Hoban ${ }^{20}$ que, a partir do exame desses estudos, concluiu:

\begin{abstract}
Sempre que a exibição da película é precedida por observações introdutórias que explicam as partes difíceis e preparam a assistência para uma observação fundada e inteligente, o índice de aprendizagem é cerca de um terço maior (over half again) do que quando o filme é rodado sem essas explicações introdutórias e motivadoras (apud JOBIM, 1964, p.40)
\end{abstract}

Jobim apoiou-se nos resultados da pesquisa publicada em artigo de Paul H. Wagner e de Leonar V. Gordon ${ }^{21}$ para explicar a eficácia desse método, levantando principalmente a função motivadora da exibição, comprovada por questionários respondidos por alunos. Citando os autores, explica que os filmes podem ser utilizados com finalidades didáticas ou informativas, precedidos ou não de introdução, mas seguidos de discussão. Mas a grande vantagem estaria na aprendizagem mais rápida e

\footnotetext{
${ }^{20}$ HOBAN, Charles F. New Movies that Teach, Nova York: 1946.

${ }^{21}$ In: Journalism Quarterly, 1950.
} 
eficiente o que resultaria numa economia de tempo "que seria dedicado às disciplinas propriamente culturais" (WAGNER; GORDON, 195022).

Além de material didático, produzido com a finalidade básica de tratar determinados temas abordados no ensino do jornalismo, outros materiais audiovisuais também podem ser utilizados, como os de caráter promocional produzidos por empresas jornalísticas de diferentes países. Filmes exibidos no cinema, que abordam as atividades jornalísticas ou assuntos afins, da mesma forma podem ajudar na discussão de questões fundamentais da profissão.

Finalmente, Jobim discute a necessidade do aluno de jornalismo conhecer os pormenores do produto acabado das atividades para as quais se está preparando. Desde o início do curso é preciso que ele seja motivado a descrever os jornais que lê, explicando os motivos da leitura. Mais adiante, o autor sugere propor aos estudantes um trabalho de pesquisa sobre jornais de diferentes categorias, com os objetivos de conhecer: as características de cada um, tanto na parte editorial quanto na parte não editorial; os espaços dedicados à opinião e às diversas categorias de informações; as editorias especializadas; o espaço destinado aos assuntos de interesse humano, pitorescos ou de entretenimento; o projeto gráfico, com os espaços dedicados aos títulos e ao texto, bem como o ocupado pelas ilustrações; a orientação política de cada um; e o grau de editorialização da informação em cada um,

${ }^{22}$ Apud Jobim, 1964, p. 40. 
assinalando títulos e textos editorializados, para avaliação e informação posterior.

O fato é que esse tipo de pesquisa resulta numa atividade de ensino ativo, que leva os alunos a se interessar por aquilo que devem aprender. Para Jobim, essa é a verdadeira missão do professor: estimular o aluno querer aprender, "estimulando-o e orientando-o para que, na intensiva atividade mental, sem desperdício de energia e de tempo, aprenda a assimilar realmente as noções ou hábitos formativos e informativos que valorizam o homem em sua comunidade". 


\section{O ensino atual nas escolas pioneiras}

Sem dúvida alguma, as faculdades de jornalismo tiveram - e ainda têm - um papel importantíssimo no processo de profissionalização do jornalismo. Não que tenham atuado sozinhas nesse sentido, mas deram sua contribuição fundamental na construção não apenas de formação humanística e de técnicas profissionais, mas na construção de uma deontologia, de um conjunto de valores que pautam o dia-a-dia, o comportamento e a ação desse profissional, numa nova forma de pensar a profissão. Desde o primeiro curso, como apontado por Danton Jobim em seus textos, as faculdades se mostraram atentas à modernização da imprensa e ao modelo de profissionalização do jornalismo.

É certo que, mesmo com todas as carências e deficiências, mesmo não formando o profissional ideal, a faculdade é o principal espaço para dar formação técnica e teórica mais adequada e consolidar valores. Por isso é importante compreender que caminho elas estão tomando e para onde segue o ensino de jornalismo, num período em que, mais do que as ocorridas na década de 1950, a imprensa está passando por profundas transformações.

O jornalismo vive hoje um momento muito particular na sua história, de transformação no campo profissional, onde ainda não se vislumbra aonde vai parar ou se vai parar. As mudanças tecnológicas tiveram e estão tendo um forte impacto na profissão, inclusive reconfigurando o 
próprio mercado empresarial. Ninguém aposta com certeza no que vai acontecer: convergências de mídias, telejornalismo on-line, outras formas de linguagem, outras formas de informar, nada está muito consolidado. Até mesmo a linguagem da internet, presente há algum tempo na vida das pessoas, ainda está sendo experimentada. Por isso mesmo, este é um momento de experimentação no campo que pode ser enriquecedor.

\section{A nova Cásper Líbero}

O que mudou na Faculdade Cásper Líbero desde sua fundação? Pesquisa recente da professora Rosalba Facchinetti (2006) sobre o curso de jornalismo apontou a questão, a nosso ver primordial, sobre a deficiência mais sentida pelos alunos e levantada por Jobim há quase 50 anos: a deficiência na formação cultural do aluno. Facchinetti reproduz a crítica de um aluno: "Cultura geral, é o conteúdo... na hora de escrever não adianta conhecer a tecnologia se falta cultura geral, a gente não consegue escrever".

A pesquisadora aponta, numa das escolas mais reconhecidas no país na área de jornalismo, alguns problemas que com certeza são sentidos na maior parte dos cursos brasileiros: uma inadequação da parte teórica com a parte prática no projeto pedagógico; a pouca preocupação da instituição com a formação dos professores - valorizando mais a atuação profissional que a qualificação, burlando, inclusive, a legislação que obriga a contratação de mestres e doutores, prática comum nas 
instituições de ensino particulares - o que pode comprometer a qualidade da parte teórica; a prevalência da tecnologia (a faculdade tem laboratórios de alta qualidade) em detrimento do conteúdo; a falta de exigência para que os alunos se envolvam na produção dos veículos laboratórios que a faculdade disponibiliza; além da quase inexistência de atividades relacionadas à comunidade, as chamadas atividades de extensão.

Como dissemos, esses são problemas que afetam a grande maioria das escolas particulares de jornalismo, mais preocupadas com o lucro, inseridas dentro da lógica de mercado. Como o investimento em tecnologia tem que ser cada vez maior, a contratação de docentes sem a qualificação ideal torna-se uma maneira de equilibrar os custos. Isto gera outro problema: a falta de dedicação maior do docente às atividades acadêmicas, que implica em prejuízo na interdisciplinaridade ou no diálogo entre as disciplinas. Os professores não discutem com os colegas sobre formas de integração, fazendo com que o aluno não encontre relação entre elas. Esse é um fator que pode gerar, muito provavelmente, a desmotivação em relação às matérias não técnicas, ponto essencial no ensino, segundo Jobim. Ainda existe o problema de, mesmo nas matérias técnicas, não haver uma continuidade de conteúdo, caso das disciplinas que requerem aprofundamento a cada semestre (Ex: Técnicas de Redação Jornalística I, II e III).

Pouco depois da pesquisa de Rosalba Facchinetti, a Cásper Líbero fez uma nova alteração curricular - no ano de 2006 -, que aponta para o que comentamos há pouco: o currículo foi reestruturado (Anexos $\mathrm{B}$ e $\mathrm{C}$ ), 
com a diminuição de algumas horas aulas ${ }^{23}$, o que afetou especialmente disciplinas como Língua Estrangeira e Educação Física e diminuiu a carga horária de Design Gráfico - Jornalismo em Revista. Embora no total a redução na carga seja de apenas 64 horas aulas, a disciplina Projetos Experimentais passou de 288 para 448 horas aula, o que pode representar um aumento no tempo de atividade do aluno, mas não necessariamente um aumento da carga horária do professor, já que geralmente nesse período o estudante tem apenas orientações esporádicas com seus mestres.

\section{O atual curso de jornalismo da UFRJ}

Já a Escola de Comunicação (ECO) da Universidade Federal do Rio de Janeiro, a antiga Universidade do Brasil, não enfrenta problemas com a qualificação do corpo docente, exatamente por ser uma universidade pública, que geralmente exige, para o início da carreira docente, o grau de Mestre. Dos atuais 62 docentes do curso de Comunicação Social, 52 têm doutorado ou pós-doutorado. Dos demais, apenas dois professores auxiliares têm apenas a graduação e oito assistentes têm mestrado.

Mas a ECO não foge à regra quando se trata de "comunicação" entre as disciplinas. A chefe do Departamento de Jornalismo, Ana Paula

\footnotetext{
${ }^{23}$ A grade curricular passou de 2.816 para 2.752 horas aula.
} 
Goulart Ribeiro $^{24}$, reconhece que esse é um problema difícil de resolver, embora tal discussão seja freqüente nas reuniões.

\begin{abstract}
No curso que coordeno, eu não consigo fazer com que as disciplinas "conversem" umas com as outras. Nós temos discutido muito isso nas reuniões, inclusive com os coordenadores de outras habilitações e com a coordenadora do ciclo básico. Fazer as disciplinas dialogarem, inclusive as teóricas com as práticas e o ciclo básico com o ciclo profissional, é a preocupação grande que temos tido. Evitar ter conteúdos que faltem ou duplicados, e que os alunos possam entender que uma coisa que eles viram numa disciplina tem a ver com o que eles viram na outra, nós temos essa preocupação, mas isso não é fácil.
\end{abstract}

A jornalista e professora aposentada da UFRJ Ana Arruda Callado ${ }^{25}$ insiste que o problema está centrado na falta de projetos conjuntos entre os professores. Ela acredita que boa parte da questão envolve vaidades pessoais dos professores, além da dificuldade de trabalhar em equipe. Isso impediria, segundo a jornalista, que cada um tivesse seu brilho individual.

$\mathrm{Na}$ UFRJ eu tentei tanto isso [trabalhar com projetos]. Vamos fazer um jornal, escolher um determinado tema. Aí o professor de antropologia tem que entrar, o de sociologia também. No outro semestre um outro projeto, bem diferente, um jornal de 1964, por exemplo. Mas eu nunca consegui isso, vaidade dos professores, porque eles não sabem trabalhar em equipe, por querem brilhar.

Mas a implantação de um novo projeto pedagógico em 2001 foi fundamental para que o curso da UFRJ inovasse. A coordenadora acredita que a reforma curricular foi feita preocupada principalmente com dois

\footnotetext{
${ }^{24}$ Em entrevista à autora em 20/12/2006.

${ }^{25}$ Em entrevista à autora em 20/12/2006.
} 
aspectos: primeiro, com a articulação da teoria com a prática, buscando o equilíbrio, acabando com uma divisão que, ela acredita, dá a sensação de serem dois cursos, onde nos dois primeiros anos ministra-se exclusivamente teoria e, nos dois últimos, essencialmente prática. Essa divisão, segundo a professora, é muito prejudicial para a formação do profissional de jornalismo. Um segundo aspecto foi proporcionar ao aluno um currículo flexível que o ajude a construir o seu próprio percurso, oferecendo um número maior de disciplinas optativas.

O aluno, quando presta o concurso vestibular da UFRJ não indica uma habilitação específica; ingressa no curso de Comunicação Social. Apenas no terceiro semestre do ciclo básico (Anexo D) é que faz a opção. O ciclo básico, no entanto, não oferece apenas disciplinas teóricas ${ }^{26}$. Dentro da grade são oferecidas várias disciplinas laboratoriais, e o aluno pode optar por duas delas. Segundo Ana Paula, é uma forma de ajudar o estudante a escolher mais conscientemente a habilitação que pretende seguir.

É a partir do quarto semestre que o estudante ingressa no ciclo profissional (Anexo E). Esse ciclo é formado por quatro grupos de disciplinas: as obrigatórias, as complementares de teoria, as complementares de habilitação, além das complementares de livre

\footnotetext{
${ }^{26}$ O ciclo básico é composto por 19 disciplinas e mais dois laboratórios, todos com 60 horas aulas. As disciplinas são as seguintes: Língua Portuguesa I e II; Linguagem Gráfica; História da Comunicação; Comunicação e Artes; Teoria da Comunicação I, II e III; Comunicação e Realidade Brasileira; Comunicação e Filosofia; Linguagem audiovisual I e II; Sistemas e Tecnologia da Comunicação; Comunicação e Economia; Comunicação, Psicologia e Cognição; Sistemas de Informação; Comunicação e Mercadologia; Fotografia; e Antropologia e Comunicação.
} 
escolha. Do grupo de disciplinas obrigatórias fazem parte aquelas consideradas absolutamente fundamentais para qualquer jornalista, mas é composto por um número reduzido de matérias. Nesse núcleo entram as disciplinas de Redação Jornalística I e II, Técnicas de Reportagem I e II, Telejornalismo I, Radiojornalismo I, Jornalismo Gráfico, História do Jornalismo, Fotojornalismo, Assessoria de Imprensa, Edição Gráfica, e Legislação e Ética em Comunicação.

As complementares de habilitação são as disciplinas específicas de jornalismo, mas nenhuma delas é obrigatória. Geralmente é um aprofundamento de disciplinas obrigatórias - como no caso de Telejornalismo II ou Radiojornalismo II - ou ligadas ao jornalismo especializado - casos do Jornalismo Esportivo, do Jornalismo Econômico e do Jornalismo Científico, entre outros. Dentro de cada semestre, o aluno deve cursar uma disciplina de 30 horas dentro dessa categoria, totalizando 180 horas ao final do curso.

As complementares de teoria também são distribuídas ao longo de todos os semestres, sendo obrigatório o estudante cursar uma disciplina de 60 horas em cada um, totalizando 240 horas. O interessante dessa proposta, de acordo com a chefe do departamento, é a união da teoria com a prática, concepção que, como dissemos, norteou o novo projeto pedagógico. Ana Paula acredita que é uma forma de driblar a eterna discussão sobre o que deve ser privilegiado nas estruturas curriculares para a formação do jornalista, discussão esta presente desde a criação do primeiro curso. "Até hoje, por mais que se discuta, ainda é um dilema. 
Alguns acham que o curso tem que ser mais técnico, outros defendem que deva ser mais teórico, outros acham que tem de haver um equilíbrio", reforça, reconhecendo que esse é um problema muito sério, e que se agrava em função das disciplinas teóricas serem sempre colocadas logo no início do curso.

Finalmente, no grupo das complementares de livre escolha, o estudante pode optar por cursar disciplinas em Comunicação ou em qualquer outra área do conhecimento nas unidades da UFRJ. Ana Paula explica que, dessa forma, ele pode construir o seu currículo de acordo com seu interesse. Cita, como exemplo, o caso de um aluno que esteja mais voltado para a área de economia: ele pode, nas complementares de habilitação, escolher a disciplina de Jornalismo Econômico e, nas complementares de livre escolha, optar por cursar Introdução à Economia, na Faculdade de Economia, ou História Econômica do Brasil ou História Econômica Geral, na Faculdade de História. O estudante deverá cumprir 240 horas de disciplinas de livre escolha. Sem dúvida, o currículo flexível ajuda o aluno a construir a formação que pretende ter, ajuda a construir seu próprio percurso.

Embora a estrutura curricular da Escola de Comunicação da UFRJ indique uma proposta avançada de ensino, seu antigo prédio - o Palácio da Praia Vermelha - localizado na Urca, zona sul do Rio de Janeiro, suntuoso por fora e decadente por dentro, indica o grave problema de falta de verbas que sofrem as universidades federais no Brasil. As instalações são decadentes. Ana Paula reconhece que existem sérias dificuldades 
para oferecer todas as disciplinas previstas, como a falta de professores, além da falta de equipamentos. Mas acrescenta que a atual direção tem trabalhado para minimizar os problemas.

Exemplo disso são os novos laboratórios, como o TJUFRJ, o laboratório de Telejornalismo Online dirigido pela professora Beatriz Becker Rieper. Os alunos desenvolvem no laboratório, além da prática do telejornalismo na internet, pesquisas relacionadas com a nova tecnologia da comunicação e com as novas linguagens.

Outros laboratórios, como o CPM, Centro de Produção Multimídia, estão bem equipados. Mas Ana Paula, numa comparação com os laboratórios de primeiro mundo instalados em algumas faculdades particulares, observa que de pouco adianta laboratórios de altíssima qualidade sem recursos humanos competentes. Mesmo o jornallaboratório do curso de jornalismo, que tinha problemas para circular com regularidade, agora sai periodicamente.

\section{O legado de Danton Jobim}

Há 50 anos Danton Jobim já pregava a importância da formação de um profissional crítico, capaz de acompanhar as transformações do seu tempo, evocando Dewey que defendia que o processo educacional não tem um fim além de si mesmo e que a educação é um processo de 
contínua reorganização, construção e transformação. Portanto, não se pode conceber educação como um processo de preenchimento de vazios.

O ensino do jornalismo, num momento de modificações na profissão, deve ter como prioridade a formação de um profissional preocupado com as mudanças e as novidades, mas também com uma formação sólida capaz de fazer com que se adapte aos novos tempos.

Não se trata de dar ao aluno uma formação baseada no que se faz no mercado, porque o mercado está dinâmico, se modificando da noite para o dia. Mas de prepará-lo para novos campos profissionais, de torná-lo um protagonista de seu tempo, capaz de propor mudanças criativas, inovadoras, assim como fez Jobim em seu tempo.

De sua proposta pedagógica, percebe-se uma grande influência no atual projeto pedagógico da Escola de Comunicação da UFRJ. A principal delas talvez seja na participação do aluno no processo de aprendizagem. Oferecendo ao estudante a possibilidade de escolhas na sua formação, a escola reforça o conceito de Jobim de que só se aprende o que realmente se quer aprender. Dessa forma, traz ao aluno a motivação para aprender as disciplinas de seu interesse, tornando-o um agente de sua própria formação.

Da mesma forma, outra contribuição pode ser vista na associação das disciplinas de humanidades com a comunicação, como pode ser visto no ciclo básico (Comunicação e Filosofia, Antropologia e Comunicação, Comunicação e Artes, entre outras), associando os nexos necessários entre o ensino dessas disciplinas com o processo da comunicação social. Jobim propunha o ensinamento das humanidades voltadas para 0 
jornalismo, associando os fatos, e trazendo para as questões da realidade dos nossos tempos.

O cerne da concepção do novo currículo, a integração das disciplinas teóricas e práticas, também era uma das prioridades de Jobim ainda nos anos de 1960. Pouco se avançou nesse sentido e essa continua a ser a grande queixa dos alunos. A vantagem da ECO é a tentativa de fazer essa integração, principalmente quando a teoria pode ser eletiva. Deixando que o aluno escolha suas disciplinas, as reclamações diminuem, porque o estudante passa a ser co-autor de sua grade curricular.

Mas o grande "calcanhar de Aquiles" continua sendo a questão da formação de cultura geral do aluno. Alguns ensinamentos importantes para a formação do jornalista, na opinião de Jobim, são ignorados pela escola, ou relegados ao grupo de livre escolha; isto é, dependem do interesse do aluno. Entre esses ensinamentos encontram-se a Literatura, a História e a Geografia. Pode parecer uma regressão ensinar Geografia na universidade, dentro de um curso de jornalismo. Ana Arruda Callado ${ }^{27}$ não pensa assim:

\footnotetext{
O Danton defendia uma coisa incrível: a geografia. Como você pode comentar uma guerra no Iraque se não sabe onde fica, não conhece a questão econômica... E aí tem a tragédia da internet. Eu escutei um aluno dizer "Ana, para que a gente precisa saber isso, basta acessar a internet". As pessoas confundem conhecimento com informação. Você não tem que saber a população do Iraque, para isso você tem que acessar o Google. A internet é maravilhosa para isso. Mas você tem que ter idéia da formação do Iraque, dos seus vizinhos do Iraque, etc. A importância da geografia e da história é fundamental e muito útil. Os alunos não sabem porque o colégio é ruim, não ensina mais nada
}

\footnotetext{
${ }^{27}$ Em entrevista à autora em 20/12/2006.
} 
A jornalista garante que o seu curso, no início da década de 1960, "que era quase um curso de humanidades" e não tinha sequer máquina de escrever, era melhor que os cursos atuais, porque incluía História da Arte, Teoria do Estado e Literatura Portuguesa e Brasileira. Lembra-se de que, quando lecionava Técnicas de Redação, fazia com que os alunos lessem primeiro as histórias do Guimarães Rosa para compreender a diferença entre discurso literário e discurso jornalístico e eles reclamavam porque achavam os textos "muito complicados". Ressalta que, embora tenha lido centenas de livros de sociologia, antropologia e história, só entendeu o país quando leu os grandes romances brasileiros. Então, como afastar os alunos da literatura? Ana Arruda vai além, associando a qualidade do texto jornalístico com o conhecimento da literatura.

Há uns 15 anos, eu cheguei à França e peguei um jornal. Na primeira página tinha uma matéria sobre o preço do cacau, uma matéria de economia, que começava assim: "Já se foi aquele tempo de fartura retratado nos romances do brasileiro Jorge Amado. A região de cacau na Bahia (...)". Era para falar sobre a queda de preço de cacau, em um jornal francês. Naquele tempo, se um jornalista brasileiro escrevesse isso era crucificado, e você quer coisa mais objetiva do que isso? Porque isso é objetividade, não é nariz de cera. Aquilo acabou, o cacau agora é outra coisa. Era uma reportagem de economia para explicar claramente a situação. Então, para mim, isso é jornalismo.

Mesmo assim, a professora defende os cursos superiores, apontando a falta de qualidade do ensino médio. "O aluno entra na faculdade semi-alfabetizado, porque os colégios mal alfabetizam hoje em dia. Nunca leu nada, não sabe de nada, em três anos vai aprender tudo?" Ela acredita que as empresas jornalísticas não podem exigir que um recém-formado saia pronto para se tornar um editor, porque nem mesmo 
um médico sai da faculdade pronto para fazer uma cirurgia de coração. "Primeiro ele vai passar pela residência, vai ser o assistente do assistente do assistente". Insiste que o curso de jornalismo não é um curso mágico, que forma um editorialista em três ou quatro anos. Defende, ainda, que as empresas jornalísticas deveriam investir mais em formação. "O Danton reclamava muito que não existia uma parceria da faculdade com as empresas e continua sem existir. As empresas tinham que bancar os cursos de comunicação. Quero ver certos editores dando aula...”.

É realmente um problema cultural. Ana se queixa de que quando dava aula na PUC do Rio de Janeiro, "faculdade de elite", após a prova fazia algumas "perguntinhas" do tipo: cite cinco cineastas vivos brasileiros e cinco mortos; ou pintores. E nenhum aluno respondia. "Como é que pode ser jornalista se não vai ao museu, não conhece pintura e não tem interesse?"

A cultura se adquire com o tempo, justifica Ana Arruda, e os colégios brasileiros estão muito ruins, "o tal do segundo grau não existe". Por isso, a faculdade tem dificuldades de suprir toda a falta de informação e cultura do aluno.

Vou contar a diferença entre o jornalista de 1960 e do jornalista de hoje. O Jornal do Brasil recebia toda a semana a visita de um senhor espanhol chamado Sr. Alfredo. Era um vendedor da Aguilar, aqueles livros grandes de papel arroz que eram obras copiadas. Tinha uma página inteira de caderno com o nome das pessoas do Jornal do Brasil que compravam dele. Ele dizia: "Ana, você acabou de pagar a Cecília Meirelles e saiu o Garcia Lorca". Eu respondia: "Seu Alfredo, eu sou repórter, não tenho dinheiro". E ele retrucava: "Tem sim, a gente faz baratinho". Ele vendia à prestação e vendia muito. Imagina o Sr. Alfredo entrando nas redações hoje... Morreria de fome. 
É bem verdade que nesse tempo o jornalismo tinha dois tipos de profissionais. Os repórteres com pouca ou quase nenhuma formação, que tinham capacidade de apurar bem a notícia, mas eram incapazes de escrever um texto com qualidade; e os redatores e colunistas, geralmente intelectuais ou profissionais recém-saídos da universidade, de diferentes áreas, que se encarregavam de reescrever os textos dos repórteres menos capazes. Existiam ainda os que falavam inglês, casos raros, e que eram direcionados para a editoria de internacional.

Isso justifica a explicação de Jobim (1964, p.71) sobre a pretensão das faculdades de jornalismo no Brasil:

Sustentamos, por outro lado, que uma escola de jornalismo não foi feita para formar grandes repórteres ou editores, mas sim para elevar o nível do pessoal empregado nas atividades de redação, dando-lhes ao menos uma base humanística razoável e ensinando-lhes o que se chama os "segredos do metier".

Palavras surpreendentes para quem defendia o ensino do jornalismo, mas compreensíveis dentro do contexto geral da profissão na década de 1950. Ana Arruda conta que quando entrou no Jornal do Brasil, em 1958, disseram-lhe para não contar que fazia faculdade, porque os colegas iriam rir dela. Os profissionais mais qualificados geralmente vinham do curso de Direito e alguns do curso de Letras, alguns altamente gabaritados.

Essa, provavelmente, também era a razão que fazia com que Jobim (1964, p.71) não creditasse ao curso de jornalismo a primazia ou a exclusividade de formar profissionais para as redações, embora pareça 
contraditória com a defesa de que só jornalistas (que não eram formados em jornalismo, naquela época) pudessem ensinar jornalistas.

Não estou afirmando que sejam desnecessárias as escolas de jornalismo tal como se dão em nossos países. O que sustentamos é que tais escolas não podem aspirar o monopólio da formação de jornalistas. Estão destinadas para preparar profissionais correntes e não para cortar o caminho aos excepcionalmente dotados, que se forjaram em uma boa cultura geral.

A questão cultural sempre foi colocada em foco por Jobim. Justamente ele, que trouxe e adaptou as técnicas norte-americanas num momento em que nossa influência cultural - e jornalística também - era oriunda da Europa. Ana Arruda justifica:

O Danton era muito inteligente. Mostra o tipo de expansão da cultura dele, evidentemente, da cultura francesa que era a cultura de sua época. Basta ver a quantidade de expressões em francês que ele usa no texto. Mas ele se voltou para os Estados Unidos e foi esperto para perceber que lá também havia vida inteligente. Muito pouca, é verdade, mas existia. E ele foi lá e pegou o que havia de melhor.

Foi exatamente esse conhecimento e essa aceitação de duas culturas tão distintas que possibilitou que Danton Jobim se tornasse um elemento agregador, somando as diferenças para encontrar um modelo de jornalismo e de ensino que contribuísse para a formação de um profissional mais qualificado e em busca de uma função social, que tem como propósito a melhora das condições sociais. Uma verdadeira mediação cultural em busca da concepção de jornalista que ele tinha: 
O jornalista é um perpétuo estudante, no sentido de que nunca fechará o livro das noções, dos conhecimentos gerais das humanidades modernas. E é um perpétuo investigador, porque sua curiosidade é ilimitada, não se detém diante de nenhum obstáculo. E é, todavia, um mestre, um mestre de conglomerados, que contribui para a formação do homem contemporâneo através da informação sistemática, distribuída por meio de certas técnicas de comunicação que a escola de jornalismo lhe ajuda a conhecer e a dominar (JOBIM, 1964, p.71).

E é obrigação das escolas de jornalismo formar esse profissional defendido por Jobim que, em última hipótese, ajudará a construir um mundo melhor. É obrigação das escolas encontrar o elo perdido entre teoria e prática, buscando fugir do modelo da "pedagogia de resultados" 28 . É função do professor, que tem sob sua responsabilidade a formação de centenas de jovens, defender uma pedagogia de integração. E é responsabilidade nossa, pesquisadores de jornalismo, lutar por um ensino que encontre o equilíbrio entre a cultura, a técnica e a teoria, mediação feita com maestria por Jobim, décadas atrás, que ainda não conseguimos resgatar totalmente.

\footnotetext{
${ }^{28}$ Conceito de Eduardo Meditsch (1990), inspirado no "sindicalismo de resultados", corrente do movimento sindical brasileiro identificada com a direita, mas que se considerava apolítica, adotando o lema "conservar melhorando", para garantir sua sobrevivência política.
} 


\section{Considerações finais}

Sem dúvida, o jornalismo atual deve muito de sua trajetória a Danton Jobim, o principal responsável pela reforma ocorrida na imprensa brasileira na década de 1950, comandando sua equipe no jornal Diário Carioca. No entanto, Jobim não apenas trouxe e implantou as técnicas norte-americanas, mas uniu-as à sua cultura predominantemente européia, buscando encontrar um caminho de diálogo, pontos em comum entre essas duas culturas, visando sua adaptação à realidade brasileira da época.

Da mesma forma, Jobim criou um projeto pedagógico para o jornalismo baseado nas propostas inovadoras do pragmatismo de John Dewey, que revolucionou o ensino norte-americano, modelo que Anísio Teixeira tentou implantar no Brasil, na Universidade do Distrito Federal, sem sucesso.

Novamente, assim como na prática jornalística, Jobim não apenas transferiu um modelo de sucesso dos Estados Unidos para o Brasil. Mais do que isso, aplaudiu e defendeu o modelo profissionalizante da Universidade de Colúmbia, entendendo, porém, que esse modelo precisava estar apoiado em uma base cultural mais forte no ensino brasileiro, preocupado com a criação de um profissional que pudesse informar, analisar e criticar os acontecimentos de seu tempo, relacionadoos com a própria história da civilização. 
Esta proposta, com certeza, estava relacionada com a concepção de jornalista que Jobim tinha em mente: um ser que pudesse contribuir com o seu tempo, que pudesse ter um importante papel social de formação. Assim, entendia que a escola de jornalismo era voltada para formar profissionais de um nível mais qualificado do que existia até então, atribuindo a esses profissionais uma verdadeira missão.

Em muitos de seus artigos e discursos, por exemplo, Jobim atribuía à imprensa americana a responsabilidade de ser um dos mais eficientes instrumentos de paz no continente. "Em nenhuma parte do mundo os jornaes collocam tão alto os ideaes pacifistas, numa atmosphera tão pura e elevada, tão longe e tão acima dos interesses subalternos, das tricas diplomáticas inexpressivas, dos incidentes próprios da vaidade humana" (JOBIM, 1938, p. 158).

Embora ressaltando a forte influência européia na formação de nossa cultura, trazia consigo o ideal de uma cultura panamericana. Acreditava que a América, não mais dividida entre a América de Bolívar e a América de Monroe, tinha atingido sua maioridade política e espiritual, o que abriria novos horizontes - econômicos, políticos e sociais - para nossos países. Dessa forma, em busca de um ideal democrático, via a imprensa como indissociável desse processo: "Senhores, a imprensa e a liberdade nasceram juntas".

Assim, entendia que os homens e os governos passam, mas a imprensa é uma instituição nacional ligada à história e ao destino do país, e uma peça indispensável ao equilíbrio das funções políticas, enquanto 
permanecer independente, mas com disposição para colaborar com o governo. Só assim, atingiria o seu ideal público.

É impossível ignorar, então, que todo o projeto pedagógico proposto por Jobim é o resultado desse ideal atribuído por ele à imprensa. Por certo, esse ideal condiz com sua atuação durante todos os anos em que exerceu a profissão. Da mesma forma, tem a ver com sua forte formação cultural e ética. Tem também relação com a própria personalidade de Jobim, um homem conhecido pelos companheiros como um conciliador, que buscava na diplomacia os meios de resolver conflitos, mesmo nos momentos mais graves e polêmicos.

Compreende-se essa posição a partir do próprio conceito de Dewey, de que "a motivação genuína para aprender nasce, somente, quando o objeto da aprendizagem identifica-se em algum grau com a autoexpressão do sujeito" (PENAFORTE, 2001, p.71), dentro de um processo ativo que conduz a um "movimento de identidade profunda do ser em direção a um aspecto particular do universo".

Assim, Jobim construiu seu ideal de jornalismo - e seu ideal de ensino do jornalismo -, traçando metas para formar profissionais mais capazes. Esperava, dessa forma, jornalistas com mais "atitude", palavrachave no ensino atual, onde busca-se o aluno pró-ativo, com raciocínio crítico e empreendedor. E, sem dúvida, esperava formar, assim como ele, profissionais que amassem a imprensa e fizessem dela a razão de suas vidas. 


\section{Referências bibliográficas}

ABREU, Alzira et al. A imprensa em transição. Rio de Janeiro, Editora Fundação Getúlio Vargas, 1996.

(coords.) Dicionário Histórico-Biográfico

Brasileiro pós 1930. $2^{\mathrm{a}}$ ed. revista e atualizada. Rio de Janeiro: Editora FGV, CPDOC, 2001.

ABREU, Alzira; LATTMAN-WELtMAN, Fernando; ROCHA, Dora (org). Eles mudaram a imprensa. Rio de Janeiro: Editora FGV, 2003.

ALBERTI, Verena. Manual de História Oral. $2^{\mathrm{a}}$. ed. Rio de Janeiro: Editora FGV, 2004.

AMOROSO LIMA, Alceu. 0 jornalismo como gênero literário. $2^{\mathrm{a}}$ ed. São Paulo: Edusp, 2003.

ARGOLO, José Amaral. Danton Jobim: no rastro da Operação Condor. Artigo apresentado no III Encontro da Rede Alfredo de Carvalho. Novo Hamburgo, 14 a 16 de abril de 2005. 
AZEVEDO FILHO, Leodegário A. de. Danton Jobim: jornalista da democracia e senador da liberdade. Rio de janeiro: Livraria Padrão Editora, 1981.

BAHIA, Juarez. Jornal, História e Técnica: história da imprensa brasileira. $4^{\text {a }}$ ed. São Paulo, Ática, 1990.

BELTRÁN, Francisco. A educação intencional. In: Pedagogias do Século XX. Porto Alegre: Artmed, 2003.

BELTRÃO, Luiz. Iniciação à filosofia do jornalismo. $2^{\mathrm{a}}$ ed. São Paulo: Edusp, 2003.

BOBBIO, Pedro Vicente (org.). Decreto-lei n. 910, de 30 de novembro de 1938. Dispõe sobre a duração e condições do trabalho em empresas jornalísticas. Coletânea de Legislação Federal. Notas coordenadoras e índices sistemáticos. São Paulo: Ed. LEX, ano II, 1938.

BOLETIM DA ABI. Retrato falado de Danton Jobim. Ano XXVII. Rio de Janeiro, março de 1978.

BUENO, Wilson. O jornalismo como disciplina científica: a contribuição de Otto Groth. São Paulo, Editora Comunicações e Artes, ECA-USP, 1972. 
BUYSE, Raymond. Experimentacion en Pedagogia. $2^{a}$ ed. Barcelona: Labor, 1959.

CARVALHO, Marta Maria Chagas. O debate sobre a identidade da cultura brasileira nos anos 20: o americanismo de Anísio. Campinas: Autores Associados, 2000.

CIESPAL. Ensenanza de periodismo y médios de informacion coletiva: informe final dos seminários regionales em América Latina. Quito, Ciespal, 1965.

CLAREPĖDE, Édouard. Educação Funcional. São Paulo: Companhia Ed. Nacional, 1940.

CUNHA, Luiz Antônio. A universidade crítica. $2^{a}$ ed. Rio de Janeiro: F. Alves, 1989.

DEWEY, John. Democracia e educação: breve tratado de philosophia da educação. Trad. Rangel, Godofredo e Teixeira, Anísio. São Paulo: Companhia Editora Nacional, 1936. 
DIÁRIO CARIOCA: o máximo de jornal no mínimo de espaço. Rio de Janeiro: Secretaria Especial de Comunicação Social, 2003. (Cadernos da Comunicação. Série Memória; v.9)

DIAS, Osni Tadeu. Vitorino Prata Castelo Branco e o primeiro Curso Livre de Jornalismo do Brasil. II Encontro Nacional da Rede Alfredo de Carvalho. Florianópolis, de 15 a 17 de abril de 2004.

DIAS, Paulo da Rocha. Os relatos jornalísticos: Tobias Peuce. In: Revista Comunicação \& Sociedade, $n^{\circ}$ 33. São Bernardo do Campo: Umesp, 2000.

FACCHINETTI, Rosalba. Cásper Líbero: a primeira escola de jornalismo. In: MARQUES DE MELO, José (org.). Pedagogia da Comunicação: matrizes brasileiras. São Paulo: Angellara, 2006.

FOULQUIÉ, Paul. As escolas novas. São Paulo: Companhia Editora Nacional, 1952.

GENTILLI, Victor. Sistema midiático e crise do jornalismo: dos anos 50 à decadência posterior a 80. Tese de doutorado. Escola de Comunicações e Artes da Universidade de São Paulo, 2002. 
HIME, Gisely Valentim Vaz Coelho. A hora e a vez do progresso: Cásper Líbero e o exercício do jornalismo nas páginas d'A Gazeta. Dissertação de Mestrado. Escola de Comunicações e Artes da Universidade de São Paulo, 1997.

JOBIM, Danton. O espírito do jornalismo. $2^{a}$ ed. São Paulo: Edusp, 2003.

Uma vocação irresistível. Apud: O Globo. Rio de Janeiro, 16 de março de 1973.

Pedagogia del periodismo: metodos de ensenanza orientados para la prensa escrita. Quito: Ciespal, 1964.

Problemas do nosso tempo. Rio de Janeiro: s/ed., 1938

KOBAYASHI, Elisabeth Mayumy. Vitorino Prata Castelo Branco: pioneiro no ensino de jornalismo. Artigo apresentado no II Encontro Nacional da Rede Alfredo de Carvalho. Florianópolis, de 15 a 17 de abril de 2004.

LAGE, Nilson; FARIA, Tales; RODRIGUES, Sérgio. Diário Carioca: o primeiro degrau para a modernidade. Artigo apresentado no II Encontro 
Nacional da Rede Alfredo de Carvalho. Florianópolis, 15 a 17 de abril de 2004.

LAURENTI, Maria Elisabete Antonioli. Liberdade curricular nos cursos de jornalismo: a responsabilidade e o desafio na formação profissional. Tese de doutorado apresentada à ECA/USP. São Paulo, 2002.

LINS DA SILVA, Carlos Eduardo. O adiantado da hora. São Paulo, Summus, 1991.

LOURENÇO FILHO, M.B. Introdução ao estudo da Escola Nova. $12^{\mathrm{a}}$ ed. São Paulo: Melhoramentos - Fundação Nacional de Material Escolar (RJ), 1978

MARCONDES FILHO, Ciro. A Saga dos Cães Perdidos. $2^{\circ}$ ed. São Paulo: Hacker Editores, 2002.

MARQUES DE MELO, José. Contribuições para uma pedagogia da comunicação. São Paulo: Ed. Paulinas, 1974.

Gêneros opinativos no jornalismo brasileiro. Tese de livre docência apresentada à ECA-USP. São Paulo, 1983. 
Comunicação e Modernidade. São Paulo,

Edições Loyola, 1991.

Cásper Líbero, pioneiro do ensino de jornalismo no Brasil, in: MARQUES DE MELO, José (org.), "Transformações do jornalismo brasileiro: ética e técnica". São Paulo: Intercom, 1994.

História do Pensamento

Comunicacional: cenários e personagens. São Paulo: Paulus, 2003a.

História social da imprensa. Porto Alegre,

EDIPUCRS, 2003b.

Memória em movimento: a participação brasileira na comunidade mundial das ciências da comunicação. Comunicação apresentada ao Seminário "O pensamento comunicacional brasileiro". Porto Alegre, julho de 2004a.

O pioneirismo de Danton Jobim na pesquisa jornalística brasileira. Conferência proferida na sessão de 
abertura do X Simpósio de Pesquisa em Comunicação da Região Sudeste. Rio de Janeiro, dezembro de 2004b.

\section{Lutas acadêmicas e resistências}

intelectuais: trajetória do jornalismo e da comunicação nas universidades latino-americanas. In: Revista Comunicação \& Sociedade, ano 27, n 44. São Bernardo do Campo: Umesp, $2^{\circ}$ semestre de 2005.

MARQUES DE MELO, José; FADUL, Anamaria; LINS DA SILVA, Carlos Eduardo. Ideologia e poder no ensino da comunicação. São Paulo: Cortez \& Moraes: Intercom, 1979.

MEDITSCH, Eduardo Barreto Vianna. Conhecimento do jornalismo: elo perdido no ensino da comunicação. Dissertação de mestrado apresentada à Escola de Comunicações e Artes da USP. São Paulo: ECA-USP, 1990.

MIRANDA SANTOS, Theobaldo de. Noções de didática geral. São Paulo: Nacional, 1955.

MONARCHA, Carlos (org.). Anísio Teixeira: a obra de uma vida. Rio de Janeiro: DP\&A editora, 2001. 
MOREL, Edmar. A paixão de Gustavo de Lacerda. Boletim $A B I$, Ano XXVII, Rio de Janeiro, Abril de 1978.

A trincheira da liberdade: história da Associação Brasileira de Imprensa. Rio de janeiro: Record, 1985.

PEIXOTO, Armando F. O enamorado do jornalismo. In: Boletim da ABI, Ano XXVII. Rio de Janeiro: março de 1978.

REALI, A.M.M.R.; TANCREDI, R.M.S.P. Construção de práticas pedagógicas na universidade: a busca de novos caminhos. In: Pedagogia universitária: formación del docente universitário. Colección Respuestas. Caracas: IESALC/Unesco, 2001.

RIZZINI, Carlos. O Ensino de Jornalismo. Rio de Janeiro: 1953.

SANTOS, Marli dos. Reflexões acerca do ensino do jornalismo. In: Reflexões sobre a comunicação no Brasil. Revista Estudos de Jornalismo \& Relações Públicas. Ano 1, vol. 1. São Paulo: Umesp, junho de 2003.

SODRÉ, Nelson Werneck. História da imprensa no Brasil. 4. ed. [atualizada]. Rio de Janeiro: Mauad, 1999. 
SOUZA, Paulo Renato. A universidade e a crise da educação. In: Dossiê Educação. Revista USP. São Paulo: CCS-USP, dez./jan./fev. 19901991.

SOUZA, Pompeu. A chegada do lead ao Brasil. Depoimento a ANDRADE, Aristélio, MACHADO, Luiz Paulo, AZÊDO, Maurício. In: Boletim da ABI, XXVII. Rio de Janeiro: setembro/outubro de 1978.

STEINBERGER-ELIAS, Margareth Born. As novas condições de ensino, pesquisa e extensão em jornalismo. In: 20 anos de jornalismo PUCSP. São Paulo: EDUC, 1998.

STONE, Sue. Crus Guide: 6. Interviews. Centre for Research on User Studies, University of Sheffield. Sheffield: British Library Board, 1984, p. 17-19.

SZNEJDER, Vitor. Jornalistas. Rio de Janeiro: Mauad, 2003. 


\section{Na Internet:}

FENAJ. Cursos de Jornalismo já são mais de $\mathbf{3 0 0}$ no país. Disponível em www.fenaj.org.br. Acesso em 16/08/05.

LAGE, Nilson. Para que serve um curso de Jornalismo. Artigo disponível em www.observatoriodaimprensa.com.br. Acesso em 23/09/04.

Apostilas de Jornalismo. Disponível em www.jornalismo.ufsc.

MARQUES DE MELO, José. ¿Modernidad o anacronismo? El dilema de las escuelas de comunicación en Brasil. Artigo disponível em www.felafacs.org/dialogos. Acesso em 15/01/05.

SEGISMUNDO, Fernando. Os 95 anos da ABI. Artigo disponível em http://www.cpdoc.fgv.br. Acesso em 15/01/05.

TARSITANO, Paulo Rogério. Luiz Beltrão: Vida e Obra. Artigo disponível em www.metodista.br. Acesso em 18/03/05. 


\section{Anexos}

Anexo A - Primeira página da edição de 12/02/1952 do Diário Carioca.

Anexo B - Grade curricular (Jornalismo) da Cásper Libero em vigor até 2005

Anexo C- Grade curricular (Jornalismo) da Cásper Libero em vigor a partir de 2006

Anexo D - Fluxograma das disciplinas do Curso Básico (Comunicação Social) da UFRJ

Anexo E - Fluxograma das disciplinas do ciclo profissional (Jornalismo) da UFRJ 


\section{ANEXO A}

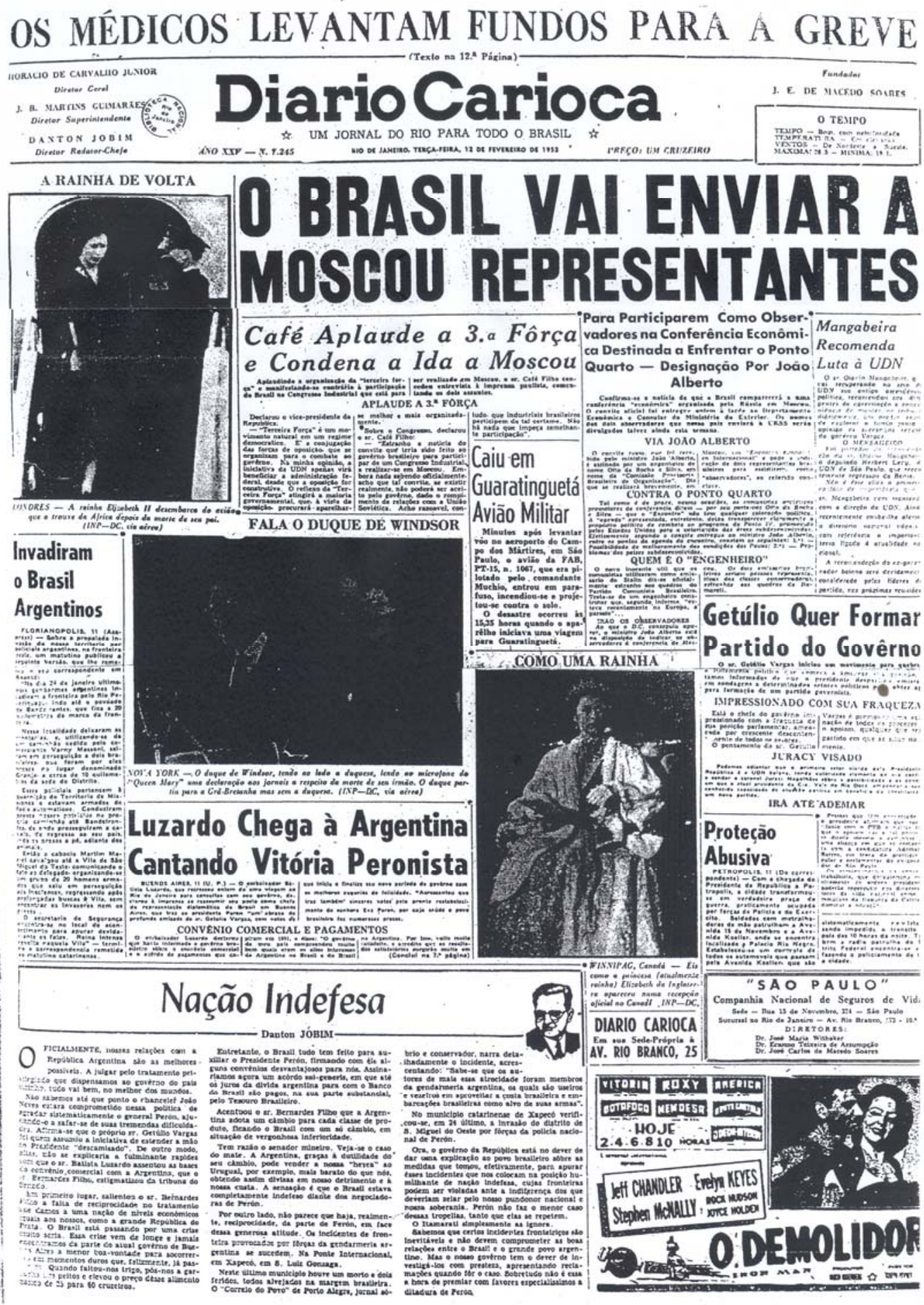




\section{ANEXO B}

\section{FACULDADE CÁSPER LÍ BERO}

GRADE CURRI CULAR (J ORNALI SMO)

EM VI GOR PARA I NGRESSANTES ATÉ 2005

\begin{tabular}{|c|c|c|}
\hline \multicolumn{3}{|c|}{$1^{\circ}$. Ano } \\
\hline Disciplinas & Carga Horária & Aulas Semanais \\
\hline Filosofia & 64 & 2 \\
\hline Língua Portuguesa I & 128 & 4 \\
\hline Sociologia Geral e da Comunicação & 64 & 2 \\
\hline Teoria da Comunicação & 64 & 2 \\
\hline Fotojornalismo & 64 & 2 \\
\hline $\begin{array}{l}\text { Computação e Planejamento } \\
\text { Gráficos Jornalismo }\end{array}$ & 64 & 2 \\
\hline $\begin{array}{l}\text { Técnicas e Gêneros Jornalísticos - } \\
\text { Jornalismo Básico I }\end{array}$ & 64 & 2 \\
\hline Antropologia & 64 & 2 \\
\hline História da Comunicação & 64 & 2 \\
\hline História do Brasil Contemporâneo I & 64 & 2 \\
\hline Educação Física & 64 & 2 \\
\hline \multicolumn{3}{|c|}{$2^{\circ}$. Ano } \\
\hline Comunicação Comparada & 64 & 2 \\
\hline $\begin{array}{l}\text { Realidade Sócio-Econômica e } \\
\text { Política Brasileira }\end{array}$ & 64 & 2 \\
\hline Língua Portuguesa II & 64 & 2 \\
\hline Jornalismo Opinativo & 64 & 2 \\
\hline Radiojornalismo I & 64 & 2 \\
\hline $\begin{array}{l}\text { Técnicas e Gêneros Jornalistícos - } \\
\text { Jornalismo Básico II }\end{array}$ & 64 & 2 \\
\hline Economia & 64 & 2 \\
\hline História da Arte & 64 & 2 \\
\hline História do Brasil Contemporâneo II & 64 & 2 \\
\hline Língua Estrangeira - Inglês & 128 & 4 \\
\hline Métodos e Técnicas de Pesquisa & 64 & 2 \\
\hline
\end{tabular}


(Anexo B - continuação)

\begin{tabular}{|c|c|c|}
\hline \multicolumn{3}{|c|}{$3^{\circ}$. Ano } \\
\hline Administração de Produtos Editoriais & 64 & 2 \\
\hline Jornalismo Especializado I & 64 & 2 \\
\hline Novas Tecnologias de Comunicação & 64 & 2 \\
\hline Radiojornalismo II & 64 & 2 \\
\hline $\begin{array}{l}\text { Técnicas e Gêneros Jornalísticos - } \\
\text { Jornalismo Básico III }\end{array}$ & 64 & 2 \\
\hline Telejornalismo I & 64 & 2 \\
\hline Ciência Política & 64 & 2 \\
\hline Cultura Brasileira & 64 & 2 \\
\hline Legislação e Prática Judiciária & 64 & 2 \\
\hline Técnica Redação I & 64 & 2 \\
\hline \multicolumn{3}{|c|}{$4^{\circ}$. Ano } \\
\hline $\begin{array}{l}\text { Design Gráfico - Jornalismo em } \\
\text { Revistas }\end{array}$ & 96 & 3 \\
\hline Ética Jornalística & 64 & 2 \\
\hline Jornalismo Especializado II & 64 & 2 \\
\hline Telejornalismo II & 64 & 2 \\
\hline Técnica Redação II & 64 & 2 \\
\hline Projetos Experimentais & 288 & 9 \\
\hline
\end{tabular}




\section{ANEXO C \\ FACULDADE CÁSPER LÍ BERO \\ NOVA GRADE CURRI CULAR (J ORNALI SMO) \\ EM VI GOR A PARTIR DE 2006}

\begin{tabular}{|l|c|c|}
\hline \multicolumn{2}{|c|}{$\mathbf{1}^{\circ}$ ANO } \\
\hline DISCIPLINAS & $\begin{array}{c}\text { CARGA } \\
\text { HORÁRIA }\end{array}$ & CH/S \\
\hline FILOSOFIA & 64 & 2 \\
\hline LÍNGUA PORTUGUESA I & 128 & 4 \\
\hline SOCIOLOGIA GERAL E DA COMUNICAÇÃO & 64 & 2 \\
\hline TEORIA DA COMUNICAÇÃO & 64 & 2 \\
\hline FOTOJORNALISMO & 64 & 2 \\
\hline TÉCNICAS E GÊNEROS JORNALÍSTICOS - & 64 & 2 \\
\hline JORNALISMO BÁSICO I & 64 & 2 \\
\hline ANTROPOLOGIA & 64 & 2 \\
\hline HISTÓRIA DA COMUNICAÇÃO & 64 & 2 \\
\hline HISTÓRIA DO BRASIL CONTEMPORÂNEO I & $\mathbf{6 4 0}$ & $\mathbf{2 0}$ \\
\hline TOTAL & & \\
\hline
\end{tabular}

\begin{tabular}{|c|c|c|}
\hline \multicolumn{3}{|l|}{$2^{\circ}$ ANO } \\
\hline COMUNICAÇÃO COMPARADA & 64 & 2 \\
\hline $\begin{array}{l}\text { REALIDADE SÓCIO-ECONÔMICA E POLÍTICA } \\
\text { BRASILEIRA }\end{array}$ & 64 & 2 \\
\hline LÍNGUA PORTUGUESA II & 64 & 2 \\
\hline RADIOJORNALISMO I & 64 & 2 \\
\hline $\begin{array}{l}\text { TÉCNICAS E GÊNEROS JORNALÍSTICOS - } \\
\text { JORNALISMO BÁSICO ॥ }\end{array}$ & 64 & 2 \\
\hline $\begin{array}{l}\text { COMPUTAÇÃO E PLANEJAMENTO GRÁFICO EM } \\
\text { JORNALISMO }\end{array}$ & 64 & 2 \\
\hline HISTÓRIA DA ARTE & 64 & 2 \\
\hline HISTÓRIA DO BRASIL CONTEMPORÂNEO II & 64 & 2 \\
\hline MÉTODOS E TÉCNICAS DE PESQUISA & 64 & 2 \\
\hline ECONOMIA & 64 & 2 \\
\hline TOTAL & 640 & 20 \\
\hline
\end{tabular}


(Anexo C - continuação)

\begin{tabular}{|c|c|c|}
\hline \multicolumn{3}{|l|}{$3^{\circ}$ ANO } \\
\hline ADMINISTRAÇÃO DE PRODUTOS EDITORIAIS & 64 & 2 \\
\hline JORNALISMO ESPECIALIZADO I & 64 & 2 \\
\hline NOVAS TECNOLOGIAS DE COMUNICAÇÃO & 64 & 2 \\
\hline RADIOJORNALISMO II & 64 & 2 \\
\hline $\begin{array}{l}\text { TÉCNICAS E GÊNEROS JORNALÍSTICOS - } \\
\text { JORNALISMO BÁSICO III }\end{array}$ & 64 & 2 \\
\hline TELEJORNALISMO I & 64 & 2 \\
\hline CIÊNCIA POLÍTICA & 64 & 2 \\
\hline CULTURA BRASILEIRA & 64 & 2 \\
\hline LEGISLAÇÃO E PRÁTICA JUDICIÁRIA & 64 & 2 \\
\hline TÉCNICA DE REDAÇÃO I & 64 & 2 \\
\hline TOTAL & 640 & 20 \\
\hline
\end{tabular}

\begin{tabular}{|l|c|c|}
\hline \multicolumn{2}{|c|}{$4^{\circ}$ ANO } \\
\hline DESIGN GRÁFICO - JORNALISMO EM REVISTAS & 64 & 2 \\
\hline ÉTICA JORNALÍSTICA & 64 & 2 \\
\hline JORNALISMO ESPECIALIZADO II & 64 & 2 \\
\hline TELEJORNALISMO II & 64 & 2 \\
\hline TÉCNICA DE REDAÇÃO II & 64 & 2 \\
\hline JORNALISMO OPINATIVO & 64 & 2 \\
\hline PROJETOS EXPERIMENTAIS & 448 & 14 \\
\hline TOTAL & $\mathbf{8 3 2}$ & $\mathbf{2 6}$ \\
\hline CARGA HORÁRIA TOTAL & $\mathbf{2 7 5 2}$ \\
\hline
\end{tabular}




\section{ANEXO D}

\section{ESCOLA DE COMUNICAÇÃO DA UFRJ Fluxograma de disciplinas do curso básico (todas as habilitações)}

\section{$1^{\circ}$ Período}

- Língua portuguesa I (60 h)

- Linguagem gráfica $(60 \mathrm{~h})$

- História da comunicação (60 h)

- Comunicação e artes (60 h)

- Comunicação e realidade brasileira (60 h)

- Teoria da comunicação I (60 h)

- Comunicação e filosofia (60 h)

Total: 420 horas

\section{$2^{\circ}$ Período}

- Língua portuguesa II (60 h)

- Linguagem audiovisual I (60 h)

- Sistemas e tecnologias de comunicação (60 h)

- Comunicação e economia (60 h)

- Comunicação, psicologia e cognição (60 h)

- Teoria da comunicação II (60 h)

- Laboratório de comunicação A (60 h)

Total: 420 horas

\section{$3^{\circ}$ Período}

- Linguagem audiovisual II (60 h)

- Sistemas de informação (60 h)

- Comunicação e mercadologia (60 h)

- Teoria da comunicação III (60 h)

- Fotografia (60 h)

- Antropologia e comunicação (60 h)

- Laboratório de comunicação B (60 h)

Total: 420 horas 


\section{ANEXO E}

\section{ESCOLA DE COMUNICAÇÃO DA UFRJ Fluxograma de disciplinas do ciclo profissional (JORNALISMO)}

\section{Disciplinas Obrigatórias}

$4^{\circ}$ período - 390h

Redação jornalística I (60 h)

Técnica de reportagem I $(60 \mathrm{~h})$

Fotojornalismo I (60 h)

História do jornalismo (60 h)

Complementar de teoria $(60 \mathrm{~h})$

Complementar de livre escolha $(60 \mathrm{~h})$

Complementar de habilitação (30h)

$5^{\circ}$ período $-300 \mathrm{~h}$

Radiojornalismo I (60 h)

Redação jornalística II (60 h)

Técnica de reportagem II $(60 \mathrm{~h})$

Complementar de teoria $(60 \mathrm{~h})$

Complementar de livre escolha (60 h)

Complementar de habilitação (30h)

$6^{\circ}$ período - 300h

Jornalismo gráfico (60 h)

Telejornalismo I (60 h)

Assessoria de imprensa (60 h)

Complementar de teoria $(60 \mathrm{~h})$

Complementar de livre escolha (60 h)

Complementar de habilitação (30h)

$7^{\circ}$ período - 300h

Edição gráfica (60 h)

Projeto experimental I (60 h)

Legislação e ética em comunicação (60 h)

Complementar de teoria (60 h)

Complementar de livre escolha (60 h)

Complementar de habilitação (30h)

$8^{\circ}$ período $-150+180$ horas

Projeto experimental em jornalismo (180h)

Complementar de teoria (60 h)

Complementar de livre escolha (60 h)

Complementar de habilitação (30h) 


\section{ESCOLA DE COMUNICAÇÃO DA UFRJ Fluxograma de disciplinas do ciclo profissional (JORNALISMO)}

(Anexo E - continuação)

\section{Disciplinas Complementares}

Criação radiofônica (60h)

Fotojornalismo II (60h)

Jornalismo gráfico II (60h)

Radiojornalismo II (60h)

Telejornalismo II (60h)

Administração de redação (30h)

Apresentação e interpretação em vídeo (30h)

Assessoria de comunicação (30h)

Cinema documentário (30h)

Comunicação e estatística (30h)

Dicção e interpretação oral (30h)

Gestão de organizações para comunicação (30h)

Imprensa comunitária (30h)

Jornalismo em mídiasdigitais (30h)

Jornalismo especializado A / B / C / D (30h)

Marketing para jornalismo (30h)

Marketing para rádio e TV (30h)

Métodos quantitativos em jornalismo (30h)

Seminários em comunicação A / B / C / D / E / F (30h cada) 